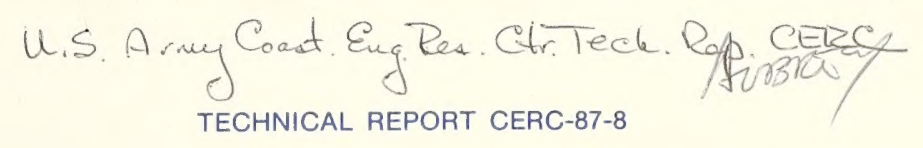

US Army Corps of Engineers

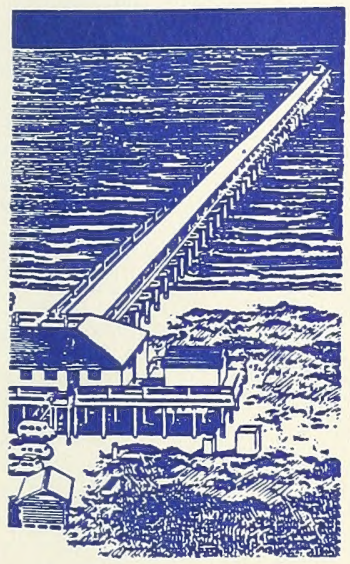

\title{
FEASIBILITY STUDY OF QUANTITATIVE EROSION MODELS FOR USE BY THE FEDERAL EMERGENCY MANAGEMENT AGENCY IN THE PREDICTION OF COASTAL FLOODING
}

\author{
by
}

William A. Birkemeier, Nicholas C. Kraus,

Norman W. Scheffner, Stephen C. Knowles

Coastal Engineering Research Center

DEPARTMENT OF THE ARMY

Waterways Experiment Station, Corps of Engineers PO Box 631, Vicksburg, Mississippi 39180-0631
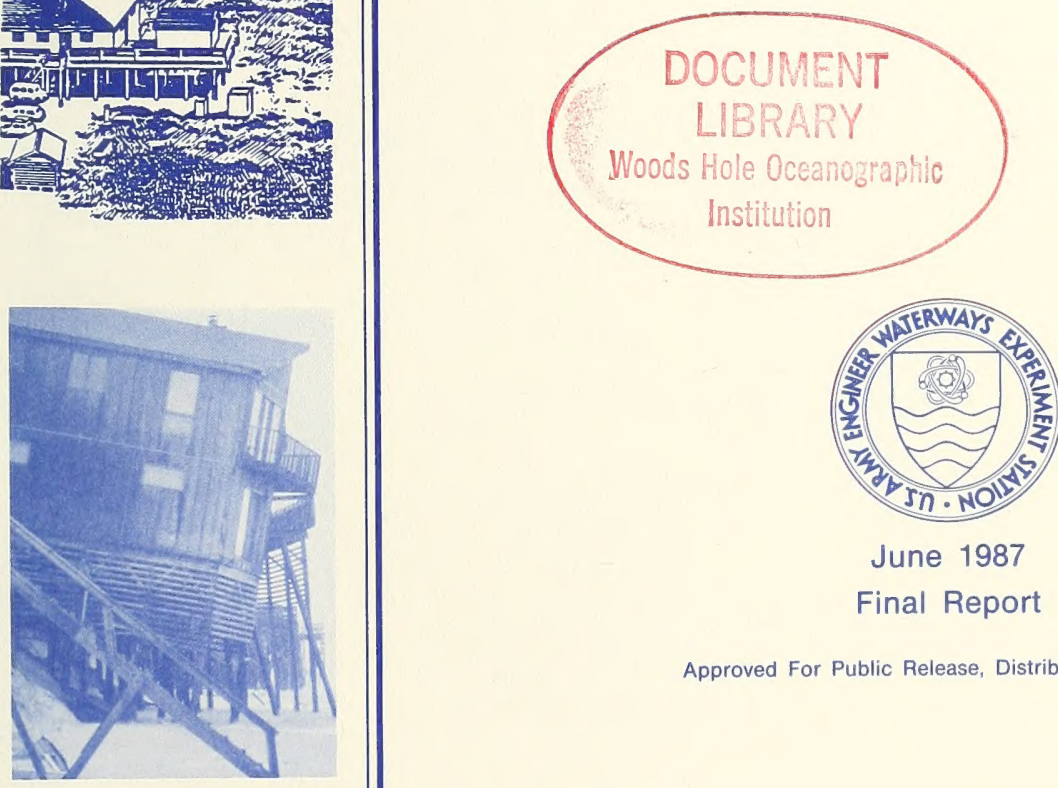

Approved For Public Release, Distribution Unlimited

Prepared for Federal Emergency Management Agency

Federal Insurance Administration

500 C Street, SW

Washington, DC 20472 
Destroy this report when no longer needed. Do not return it to the originator.

The findings in this report are not to be construed as an official

Departinent of the Army position unless so designated by other authorized documents.

The contents of this report are not to be used for advertising, publication, or promotional purposes. Citation of trade names does not constitute an official endorsement or approval of the use of such commercial products. 
Unclassified

\section{REPORT DOCUMENTATION PAGE}

\begin{tabular}{|c|c|c|c|c|}
\hline \multicolumn{2}{|l|}{$\begin{array}{l}\text { 1a. REPORT SECURITY CLASSIFICATION } \\
\text { Unclassified }\end{array}$} & \multicolumn{3}{|l|}{ 1b. RESTRICTIVE MARKINGS } \\
\hline \multicolumn{2}{|l|}{ 2a. SECURITY CLASSIFICATION AUTHORITY } & \multicolumn{3}{|c|}{$\begin{array}{l}\text { 3. DISTRIBUTION/AVAILABILITY OF REPORT } \\
\text { Approved for public release; distribution } \\
\text { unlimited. }\end{array}$} \\
\hline \multicolumn{2}{|c|}{$\begin{array}{l}\text { 4. PERFORMING ORGANIZATION REPORT NUMBER(S) } \\
\text { Technical Report CERC-87-8 }\end{array}$} & \multicolumn{3}{|c|}{ 5. MONITORING ORGANIZATION REPORT NUMBER(S) } \\
\hline $\begin{array}{l}\text { 6a. NAME OF PERFORMING ORGANIZATION } \\
\text { USAE WES, Coastal Engineering } \\
\text { Research Center }\end{array}$ & $\begin{array}{l}\text { 6b. OFFICE SYMBOL } \\
\text { (If applicable) } \\
\text { WESCV }\end{array}$ & \multicolumn{3}{|c|}{ 7a. NAME OF MONITORING ORGANIZATION } \\
\hline \multicolumn{2}{|l|}{$\begin{array}{l}\text { 6c. ADORESS (City, State, and ZIP Code) } \\
\text { PO Box } 631 \\
\text { Vicksburg, MS 39180-0631 }\end{array}$} & \multicolumn{3}{|c|}{ 7b. ADORESS (City, State, and ZIP Code) } \\
\hline $\begin{array}{l}\text { 8a. NAME OF FUNDING/SPONSORING } \\
\text { ORGANIZATION } \\
\text { See reverse. }\end{array}$ & $\begin{array}{l}\text { 8b. OFFICE SYMBOL } \\
\text { (If applicable) }\end{array}$ & \multicolumn{3}{|c|}{ 9. PROCUREMENT INSTRUMENT IDENTIFICATION NUMBER } \\
\hline \multirow{2}{*}{\multicolumn{2}{|c|}{$\begin{array}{l}\text { 8c. ADORESS (City, State, and ZIP Code) } \\
500 \text { C Street, SW } \\
\text { Washington, DC } 20472\end{array}$}} & \multicolumn{3}{|c|}{ 10. SOURCE OF FUNDING NUMBERS } \\
\hline & & \begin{tabular}{l|l} 
PROGRAM & PROJECT \\
ELEMENT NO. & NO.
\end{tabular} & $\begin{array}{l}\text { TASK } \\
\text { NO. }\end{array}$ & $\begin{array}{l}\text { WORK UNIT } \\
\text { ACCESSION NO. }\end{array}$ \\
\hline
\end{tabular}

11. TITLE (Inc/ude Security Classification)

Feasibility Study of Quantitative Erosion Models for Use by the Federal Emergency Management Agency in the Prediction of Coastal Flooding

12. PERSONAL AUTHOR(S)

Birkemeier, William A.; Kraus, Nicholas C.; Scheffner, Norman W.; Knowles, Stephen C.

\begin{tabular}{|l|l|l|l|l}
\hline 13a. TYPE OF REPORT & 13b. TIME COVERED & 14. DATE OF REPORT (Year, MONTh, DaY)
\end{tabular}

Final Report

\begin{tabular}{l|l|l|} 
FROM TO J J J J J & 1987 & 102 \\
\hline
\end{tabular}

Available from National Technical Information Service, 5285 Port Royal Road, Springfield, VA 22161.

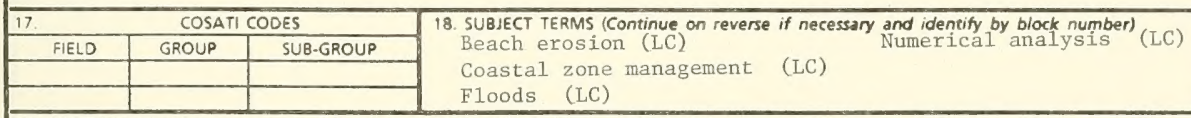

19. ABSTRACT (Continue on reverse if necessary and identify by block number)

This report examines the feasibility of accounting for the processes of erosion and overwash in the determination of coastal high-hazard flood zones, or V-zones. Included in the report are discussions of the merits and limitations of existing theoretical, empirical, and parameterized models for predicting beach profile change and dune erosion. Also included are discussions of the variability found in measured storm changes and an extensive review lof the overwash literature.

of the models evaluated, two dune erosion models were found to produce reasonable dune erosion estimates. One model (Kriebel 1982) is based on the assumption of uniform energy dissipation in the surf zone and the concept of an equilibrium profile shape which responds to a rising water level by shifting upward and landward. The other model (Vellinga 1983) was developed for use on the coast of The Netherlands and is based on a profile shape equation developed from an extensive series of large scale physical model tests.

\begin{tabular}{|c|c|c|c|}
\hline $\begin{array}{l}\text { 20. DISTRIBUTION/AVAILABILITY OF ABSTRACT } \\
\text { BI-UNCLASSIFIED/UNLIMITED } \square \text { SAME AS RPT. }\end{array}$ & DOTIC USERS & $\begin{array}{l}\text { 21. ABSTRACT SECURITY CLASSIFICAT } \\
\text { Unclassified }\end{array}$ & \\
\hline 22a. NAME OF RESPONSIBLE INDIVIOUAL & & 22b. TELEPHONE (Include Area Code) & 22C. OFFICE $5 Y M B O L$ \\
\hline
\end{tabular}


Unclassified

8a. NAME OF FUNDING/SPONSORING ORGANIZATION (Continued).

Federal Emergency Management Agency

Federal Insurance Administration

19. ABSTRACT (Continued).

Both of these models were evaluated using 14 profiles from four different storm events and found to produce comparable results. Of the two, the Kriebel model was found to be less demanding in terms of required input information (prestorm profile shape, storm surge height, etc.) and therefore easier to consistently apply. Used properly and in combination with historical data (aerial photographs and field surveys) and engineering judgment, these models can provide a consistent mechanism for the establishment of V-zones in areas prone to storm erosion. 
This report examines the feasibility of accounting for the processes of erosion and overwash in the determination, by the Federal Emergency Management Agency (FEMA), of coastal high-hazard flood zones.

The report was prepared at the Coastal Engineering Research Center (CERC) of the US Army Engineer Waterways Experiment Station (WES) in response to a request from FEMA. Dr. Frank Tsai was FEMA's contract monitor.

Mr. William A. Birkemeier, Dr. Nicholas C. Kraus, Mr. Norman W. Scheffner, and Mr. Stephen C. Knowles prepared the report under general supervision of Messrs. Curt Mason, former Chief, Field Research Facility; Thomas W. Richardson, Chief, Engineering Development Division; H. Lee Butler, Chief, Research Division; and Dr. James R. Houston and Mr. Charles C. Calhoun, Jr., Chief and Assistant Chief, CERC, respectively. Ms. Harriet M. Klein and $\mathrm{Mr}$. Peter A. Howd contributed to the preparation of the manuscript. This report was edited by Ms. Shirley A. J. Hanshaw, Information Products Division, Information Technology Laboratory, WES.

Commander and Director of WES upon publication of this report was COL Dwayne G. Lee, CE. Dr. Robert W. Whalin was Technical Director. 
PART I: INTRODUCTION . . . . . . . . . . . . . . . . 4 4

Background . . . . . . . . . . . . . . . . . . 4

Purpose .. . . . . . . . . . . . . . . . . . . 5

Scope . . . . . . . . . . . . . . . . . . . . . 6

PART II: PHYSICAL ASPECTS OF BEACH PROFILE CHANGE . . . . . . . . . . 8

Nomenclature . . . . . . . . . . . . . . . . . . . . 8

Factors Contributing to Profile Change . . . . . . . . . . . . 9

Cycle of Profile Erosion and Recovery . . . . . . . . . . . . . . 11

Overwash . . . . . . . . . . . . . . . . . . . . . 13

Equilibrium Beach Profile Concept . . . . . . . . . . . . . . 14

Natural Variation in Measured Profiles. . . . . . . . . . . . . 17

PART III: PREDICTIVE MODELS OF PROFILE CHANGE AND DUNE EROSION . . • 25

Required Characteristics of Beach Profile Change Models . . . . 25

Required Characteristics of Dune Erosion Models . . . . . . . . . 28

Numerical Models of Cross-Shore Sediment Transport

and Beach Profile Change. . . . . . . . . . . . . . . 29

PART IV: EMPIRICAL AND PARAMETERIZED MODELS . . . . . . . . . . . . 33

The Vellinga Model . . . . . . . . . . . . . . . 33

The Kriebel Model . . . . . . . . . . . . . . . . . . . 38

The Multiple Shore-Breaking Wave Transformation Model . . . . . 43

PART V: EVALUATION OF THE VELLINGA AND KRIEBEL MODELS . . . . . . . . 47

Field Data. . . . . . . . . . . . . . . . . . 47

Model Comparison. . . . . . . . . . . . . . . . . . 49

Other Evaluations . . . . . . . . . . . . . . . . . 63

Conclusions . . . . . . . . . . . . . . . . . . 63

PART VI: A SYSTEMATIC APPROACH TO V-ZONE DETERMINATION . . . . . . . 65

Use of the Model. . . . . . . . . . . . . . . . . 65

Historic Data and Long-Term Erosion . . . . . . . . . . . . . 66

Coastal Areas Suitable for Model Application . . . . . . . . . . . 68

Role of Engineering Judgment . . . . . . . . . . . . . . . 69

PART VII: SUMMARY AND CONCLUSIONS . . . . . . . . . . . . . . . . . 72

REFERENCES . . . . . . . . . . . . . . . . . . . . . . . . . . . . 74 
APPENDIX A: DISCUSSION AND ANNOTATED BIBLIOGRAPHY OF OVERWASH

LITERATURE . . . . . . . . . . . . . . . . . . . . . . A1

Introduction . . . . . . . . . . . . . . . . . . . . . . . . . . Al

Selected Bibliography on Overwash . . . . . . . . . . . . . A5 


\section{PREDICTION OF COASTAL FLOODING}

\section{PART I: INTRODUCTION}

\section{Background}

1. In 1985, an unusual sequence of three hurricanes entered the Gulf of Mexico and moved toward Grand Isle, Louisiana. Although the newly constructed protective beach and dune survived the passage of Hurricanes Danny and Elena, Hurricane Juan, which followed, caused major damage to property and leveled large sections of the remaining dune. In the same year, Hurricane Gloria posed a major threat to the east coast as the first major hurricane to pass the heavily developed mid-Atlantic shore since Hurricane Hazel in 1954. In addition to hurricanes, more frequently occurring winter storms regularly cause erosion, flooding, and property damage along the Atlantic and Pacific Ocean coasts (Figure 1).

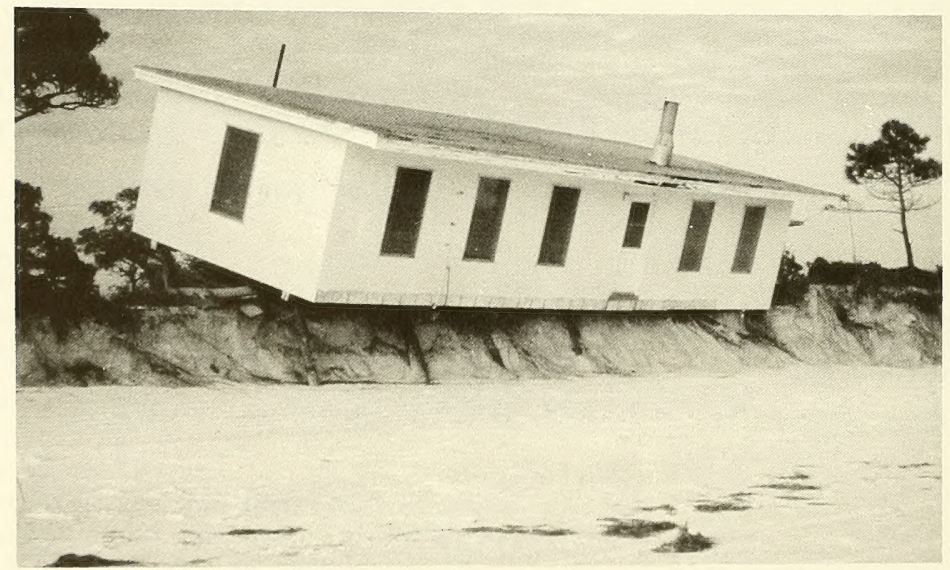

Figure 1. Storm damage caused by erosion of the dune

2. Because of the severity of coastal storms and their potential for causing loss of life and property damage, understanding and prediction of 
all aspects of storms and their impact has been a fundamental objective of coastal research. Unfortunately, the understanding of sediment transport and beach erosion lags behind the capability to predict the waves and flooding which may occur during a storm event.

3. The National Flood Insurance Program, which insures property located within coastal and inland flood-prone areas, is based on the expected flood levels associated with a storm with a 1 percent probability of occurring per year (a 100-year storm). Wave heights are considered, but there is no official procedure to treat flooding resulting from either long-term erosion or from the erosion associated with the 100-year storm. Although this may be a reasonable assumption for riverine flooding, it is not appropriate along the coast where the shoreline is constantly evolving.

\section{Purpose}

4. In December 1985, the Federal Emergency Management Agency (FEMA), which manages the National Flood Insurance Program, requested that the US Army Engineer Waterways Experiment Station's (WES's) Coastal Engineering Research Center (CERC) conduct a 6-month study to examine the feasibility of accounting for the processes of erosion and overwash in determining coastal high-hazard flood zones along the Atlantic and Gulf coasts. Specifically, this report addresses methods for determining variations in the width of the velocity ( $\mathrm{V}-$ ) zone, as defined by FEMA, which would occur if these processes could be quantitatively estimated.

5. At present, an area is designated a $\mathrm{V}$-zone only if the maximum water level associated with the 100-year storm would support a $3 \mathrm{ft}$-high $(0.9 \mathrm{~m})$ wave. In areas where dunes exist, if the dune height exceeds the water level, the dune and inland zones are assumed to be "protected," and the V-zone is topographically mapped only to the intersection of the water level with the dune. That the dune may erode or that an area is historically prone to flooding during storms is considered only by subjective means.

6. The fundamental question to be addressed is, "Will a particular dune survive the 100-year event?" Specific details as to how the dune survives (or erodes) are not required. At one extreme (the present FEMA procedure), the dunes can be treated as fixed barriers, resulting in narrow V-zones; at the other extreme, the existence of dunes can be ignored, 
resulting in wide V-zones. The latter approach would be easy to apply and in some areas may be the only rational approach. In actuality, dunes can provide an important level of protection if they are of sufficient height and width. In those areas with effective dunes, a method for estimating potential storm erosion is desirable.

7. To be of use to FEMA, a dune erosion prediction method must fulfill a number of criteria. It must

a. Be compatible with existing FEMA methodologies for computing the nearshore hydrodynamics.

b. Incorporate FEMA predictions of water level and wave height.

c. Be easy to use and allow consistent application.

d. Be relatively insensitive to uncertainty in input variables such as the prestorm beach configuration, the duration of the storm, and the sediment size.

e. Be deterministic and incorporate relationships which link the erosion process to the physical characteristics of the storm event.

f. Have undergone calibration and verification with field data.

Considerable research is currently under way which will improve both our understanding of erosion/overwash processes and our ability to predict them. This study is based on the capabilities of existing methodologies. The three candidate methodologies finally selected for detailed consideration have only recently become available, dating from 1982 or later, and work on them continues. New reports on each were published subsequent to the completion of the first draft of this report and are briefly noted here.

\section{Scope}

8. The report herein is organized into seven parts and one Appendix. Part II introduces basic nomenclature, discusses the process of beach erosion, and introduces the concept of an equilibrium profile. Part III examines in detail the requirements and suitability of theoretical sediment transport models. Part IV discusses three models which are currently used for estimating dune erosion. Two of the methods are compared in Part $V$. 
Model selection and use in V-zone determinations are discussed in Part VI.

Part VII summarizes the report and makes recommendations for future research. A review of overwash literature is included in Appendix A. 
9. This section discusses the general physical aspects of beach profile change and dune erosion. The nomenclature associated with beaches will be introduced together with the major variables believed to control profile change and dune erosion. The natural variability found in measured profile changes is quantified, and the equilibrium beach profile, a fundamental concept in present dune erosion models, is introduced. Finally, overwash, a major process associated with storms, is discussed. Supplementary discussions on the topics of beach profile change and littoral processes can be found in Volume I of the Shore Protection Manual (SPM) (1984).

\section{Nomenclature}

10. Standard nomenclature for describing beach profiles is shown in Figure 2. The locations and boundaries of various regions are somewhat ambiguous because of the dynamic nature of the beach. Definitions and names of certain features and regions may also vary from author to author.

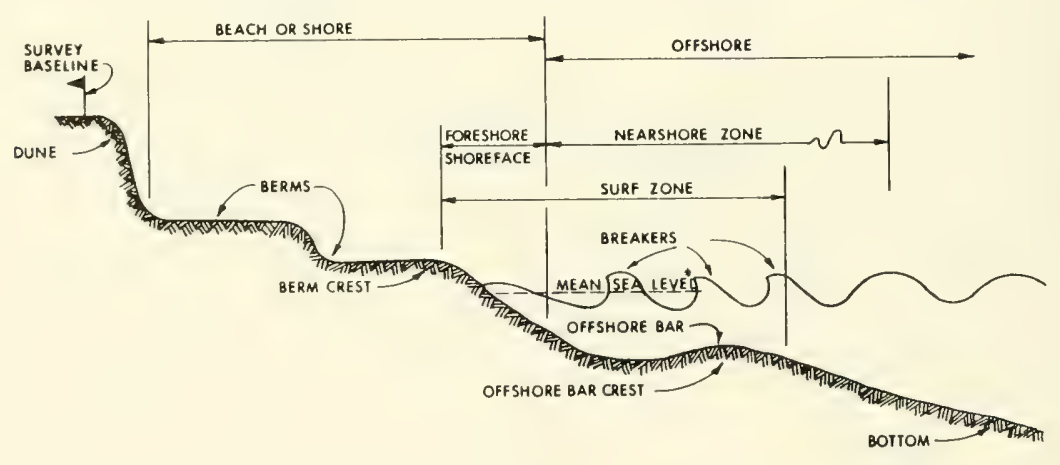

Figure 2. Profile features and terminology (SPM 1984)

11. The profile is usually measured at intervals from some point landward of the dunes, across the profile, until a depth is reached where little net sand movement is expected. This seaward limit, or "closure depth," is on the order of 6 to $8 \mathrm{~m}$ (Hallermeier 1979, Birkemeier 1985b). For convenience, the beach profile is conceptually divided into a subaqueous 
zone and a subaerial zone. The two zones shift with changes in water level.

12. The subaqueous portion of the beach profile is in continuous motion under hydraulic and mechanical forces produced by waves and currents. The regions of most intense sediment movement are located in the surf zone, from the location of wave breaking to the point of maximum wave uprush. On-offshore sediment transport is particularly intense in the swash zone and in the area of the break point of the incident waves. However, sand is in continual motion all along the subaqueous profile.

13. The subaerial portion of the beach also changes. Berms build during calmer wave conditions. Sand from the berm may be blown onshore to form dunes, or they may be created artificially. If the water level rises, the formerly subaerial portion of the beach will be unstable relative to sediment moving hydraulic forces. The berm and dune can erode by overwash (transporting sand landward) or by scour and collapse (moving beach and dune sediments seaward).

14. Beach profiles are typically classified into two basic types, either depositional (also normal, summer, swell, step type, or reflective) or erosional (also storm, winter, bar type, or dissipative) as shown in Figure 3. Other, more detailed classifications have been proposed (Sunamura and Horikawa 1975, Wright et al. 1979, Hattori and Kawamata 1981, and Wright and Short 1983).

\section{Factors Contributing to Profile Change}

15. Bruun (1962), Edelman (1968, 1972), Dean (1977), Vellinga (1983b) and others have identified an increase in water level as the most important variable relating to dune and shoreline retreat. During a storm, the "storm surge" develops as a result of the superposition of the astronomical tide, wave setup, and meteorological (wind and pressure induced) surge. This abnormally high water level permits erosive waves to attack the subaerial beach. On a less energetic scale, it has been well documented (Inman and Filloux 1960, Otvos 1965, and Hattori 1983) that cross-shore movement of sediment is closely related to the tide level.

16. A change in water level does not cause erosion; wave action is required to move the sediment. It was recognized early in the study of coastal processes (Johnson 1952) that deepwater wave height and wave 


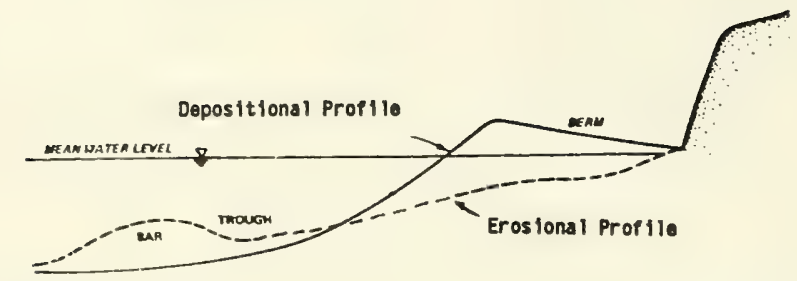

Figure 3. Erosional and depositional profile shapes (after Komar 1983)

steepness are the most important wave parameters controlling beach profile change. Wave steepness is defined as $\mathrm{H}_{0} / \mathrm{L}_{O}$, in which $\mathrm{H}_{0}$ is the deepwater wave height and $L_{O}$ is the deepwater wave length. In linear wave theory, $\mathrm{L}_{\mathrm{O}}=\mathrm{gT}^{2} /(2 \pi)$, in which $\mathrm{g}$ is the acceleration of gravity, and $\mathrm{T}$ is the wave period.

17. Johnson found that the critical wave steepness for delineating depositional and erosional profiles was in the range of 0.025 to 0.03 . Higher steepness values result in erosion; lower values cause deposition. For example, a 2-m-high, 8-sec-period wave $\left(\mathrm{H}_{\mathrm{O}} / \mathrm{L}_{\mathrm{O}}=0.02\right)$ implies a depositional profile; whereas a $2-m-h i g h, 6-s e c-p e r i o d$ wave $\left(H_{0} / L_{\circ}=0.036\right)$ results in an erosional profile. In this example the wave height is constant, and the period is different. Combinations of wave height and period are not completely random. Although higher waves usually have longer periods, storm waves typically change from high steepness, short-period waves to lower steepness, long-period waves as the storm passes.

18. Other factors affecting profile change include the beach grain size (Iwagaki and Noda 1963) or fall velocity (Dean 1973), mean beach slope (e.g., Sunamura and Horikawa 1975, and Hattori and Kawamata 1981), and magnitude of the wave height (Saville 1957). Hallermeier (1984) has recently presented a classification of the occurrence of nearshore deposition and erosion through use of a sediment mobility number and the Ursell number. Each of the above cited papers has examined or presented one or more criteria for predicting the tendency to form either an erosional or depositional profile. 


\section{Cycle of Profile Erosion and Recovery}

\section{Erosion}

19. Starting from a depositional profile characterized by a high, wide berm, steep foreshore slope, and a relatively flat offshore, if the incident wave steepness exceeds the critical steepness, the beach begins to erode. If the surge is high enough, storm waves move sand from the berm and dune offshore in the region shoreward of the main wave breaking point. As the material moves offshore, the beach slope in the surf zone becomes milder. As a result, one or more offshore bars may form, and existing bars may move farther seaward (Birkemeier 1985a). Figure 4 illustrates the offshore movement of a bar resulting from the passage of a series of three storms at Duck, North Carolina. The last and largest storm, occurring 13-15 November 1981, caused the most beach erosion and greatest seaward shift of material.

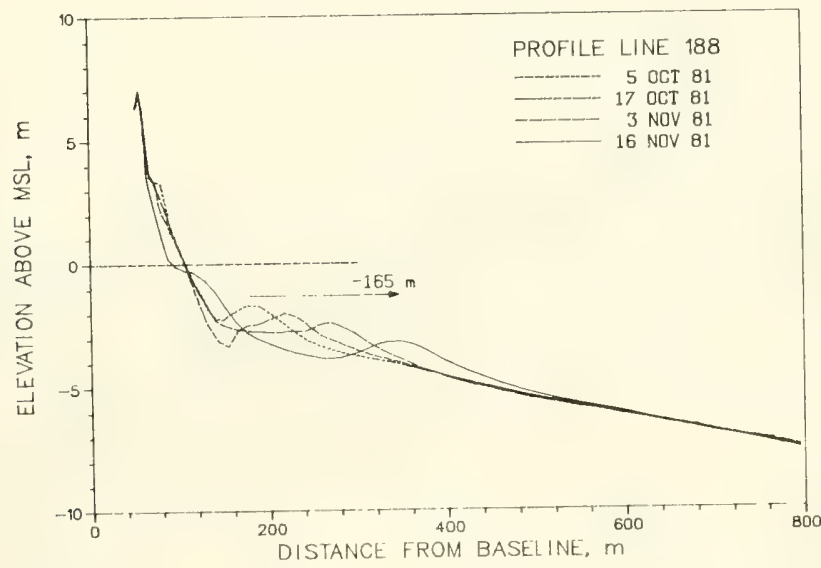

Figure 4. Offshore bar movement resulting from three storms at Duck, North Carolina (Birkemeier 1985a)

20. The mechanisms controlling offshore bar formation and movement are not well understood. Two main mechanisms are known to exist. The classical mechanism is that the bars are formed at the break point of storm waves; the 
other mechanism is that bars are formed by the convergences and divergences of mean flows associated with partially standing waves with long periods (Bowen and Inman 1971, Short 1975, and Holman and Bowen 1982). What is understood is that bars provide a natural protection to the beach by causing incoming waves to break farther offshore, reducing the energy reaching the beach. Offshore bars also provide a mechanism for the temporary storage of eroded sediments as part of the cycle toward beach recovery.

\section{Beach recovery}

21. As a storm subsides, the wave height decreases, and the wave period usually increases, eventually resulting in a wave steepness below the critical value for erosion. Then the beach recovery process begins. In the inner part of the surf zone, sand is transported onshore, and a new berm is created by the runup. Because sand is removed from the surf zone and carried onshore, the slope of the surf zone becomes steeper. The process of berm creation has been little studied and is, therefore, not well understood. The rate of beach recovery can be quite rapid; for example, Birkemeier (1979) reported that within one day of the peak of a storm, over 51 percent of the eroded material had returned to the beach at Long Beach Island, New Jersey.

22. In the offshore, the storm-induced bar will move landward and ultimately onto the beach. The rate of recovery can vary considerably depending on wave conditions and the depth over the bar. Figure 5

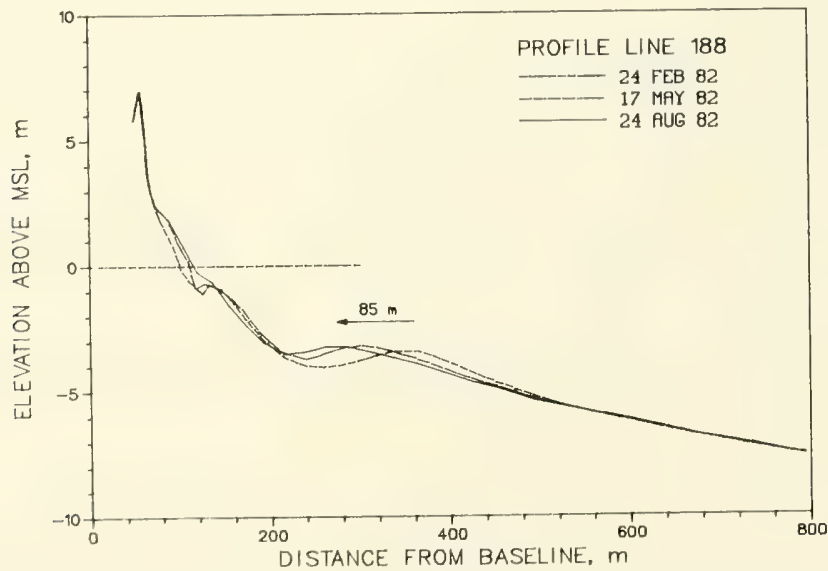

Figure 5. Slow recovery of an offshore bar at Duck, North Carolina (Birkemeier 1985a) 
illustrates the slow recovery of the bar shown in Figure 4. Recovery did not begin until the following February and continued for the next 6 months, an extended period of low wave height conditions. Recovery of shallower bars can be rapid. Sallenger, Holman, and Birkemeier (1985) measured a rate of onshore bar migration within the surf zone of $1.2 \mathrm{~m} / \mathrm{hr}$ during the waning stages of a storm when the waves were $2 \mathrm{~m}$ high with a 14-sec period.

23. Given a sufficiently long period (several months or more) of low waves, the storm bar may disappear (e.g., Birkemeier 1985a). If, however, the storm bar is located in very deep water, the bar may not be erased over an extended time scale of many years. In this case, if no other source of sand is available, the beach suffers from an apparent permanent erosion (Dean 1976).

\section{Overwash}

24. "Overwash" is a process which occurs when the storm surge and wave uprush overtop the foredune line causing water and sand to move inland. Overwash is of major importance during extreme storms when a significant percentage of a duneline may be overtopped or breached (Figure 6). It is an

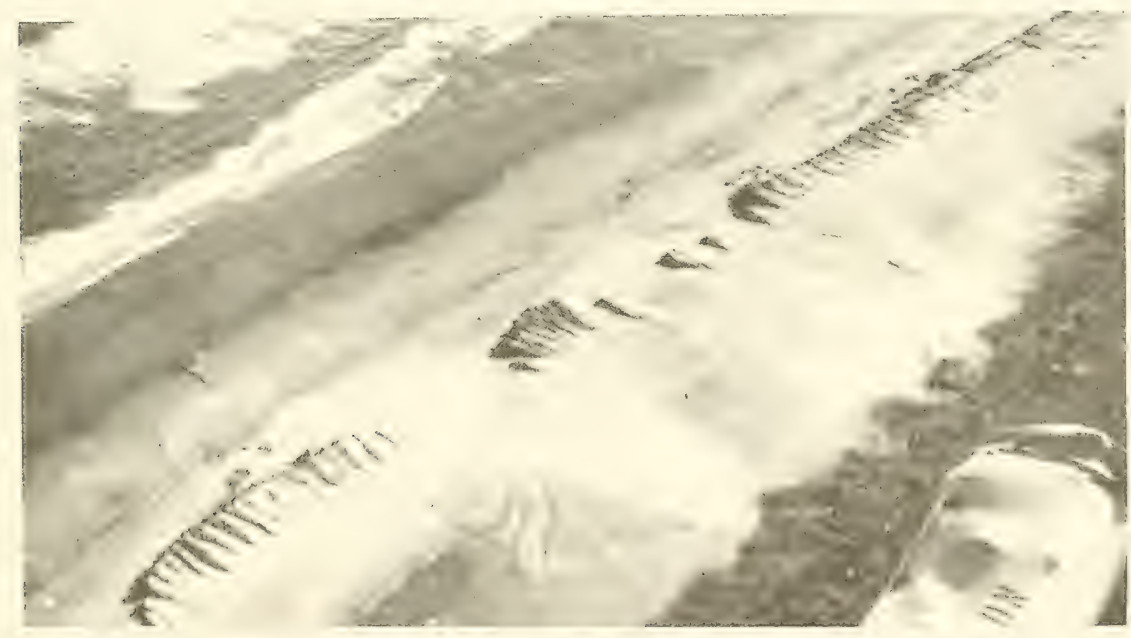

Figure 6. Breached and overtopped dune on Grand Isle, Louisiana, following Hurricane Juan in 1985 
important geological process since it provides a mechanism for barrier islands to move and to increase in elevation. Correct identification of potential overwash areas is also important in the determination of V-zones.

25. Most overwash research has been geologic in nature, with few engineering studies having been made. A comprehensive evaluation of the literature was conducted and, to the authors' knowledge, no analytical model of the overwash process exists except that developed in an M. S. thesis by Williams (1978). However, the laboratory tests and theory of Williams were inconclusive. Neither the two-dimensional (2-D) dune response to overtopping nor the three-dimensional problem associated with dune breaching has been adequately studied to permit numerical simulations of the overwash process. The Multiple Shore-Breaking Wave Transformation (MSBWT) model of Balsillie (1984c, 1985b) has provision for determining wave heights over both breached and flooded profiles as well as a mechanism for estimating overwash deposition, but the model is not fully operational or verified. * A detailed discussion on this model is given in Part III. Other studies quantify the percentage of island overwashed (Pierce 1969, and Boc and Langfelder 1977) or address volumetric changes (Schwartz 1975, and Leatherman 1976, 1981). The results of the literature survey, together with a summary of overwash knowledge for specific case examples, are contained in Appendix A. A procedure for accounting for overwash in $V$-zone determination is discussed in Part VI.

\section{Equilibrium Beach Profile Concept}

26. It is evident to the most casual observer that the beach profile has an apparent constancy of shape. When we visit a particular beach, the profile looks more or less the same, year after year. This is most easily explained using the concept of an "equilibrium profile" which continually evolves to be in equilibrium with whatever wave and water level conditions exist. This concept is fundamental to existing predictive models of dune erosion.

* Information obtained from personal communication with J. H. Balsillie, Division of Beaches and Shores, Florida Department of Natural Resources, Tallahassee, Fla., June 1986. 
27. On an idealized 2-D profile, waves provide the mechanism for cross-shore movement of sand, with movement either onshore or offshore depending on wave steepness. If constant wave and water level conditions continue for an extended period of time, an equilibrium shape will be approached. The development of this equilibrium profile has been demonstrated with physical model tests using monochromatic waves (e.g., Saville 1957, Swart 1974, and Chesnutt 1978). In general, laboratory experiments have used constant water depths and an initial plane beach profile. Measured changes are greatest at the start of the test, gradually decreasing with time. Since true equilibrium is difficult to obtain in the laboratory, it is generally believed to be seldom reached in nature.

28. Profile changes resulting from changes in wave characteristics may be thought of as perturbations on a smoother, more idealized profile shape that more or less retains a constant form in equilibrium with the mean water level, mean waves, and beach grain size. As the water level changes, this equilibrium profile shifts accordingly, moving inland and upward with increasing water level. The shape of the profile is maintained by erosion of the beach and deposition offshore. Profiles are more likely to be in equilibrium with long-term effects such as sea level rise but not with shortduration storm surges.

29. In an empirical study of beaches on the north Danish coast and in California, Bruun (1954) found that the representative, gradually deepening beach profile was well described by a simple equation of the form

$$
h(x)=A x^{2 / 3}
$$

where

$$
\begin{aligned}
& \mathrm{h}=\text { depth } \\
& \mathrm{x}=\text { distance from the shoreline } \\
& \mathrm{A}=\text { dimensional factor having units of length to the one third power }
\end{aligned}
$$

A definition sketch is given in Figure 7. Dean (1977) found the same relationship empirically for 502 profiles along the Atlantic Ocean coast of the United States. Subsequent work (e.g., Hughes 1978, and Moore 1982) has verified the basic validity of Equation 1 for beach profiles in various parts of the world and for profiles generated in laboratory flumes and basins with sand bottoms. Although the two-third power law does not exhibit bars and 
troughs, it represents a best fit description of a profile passing through such features.

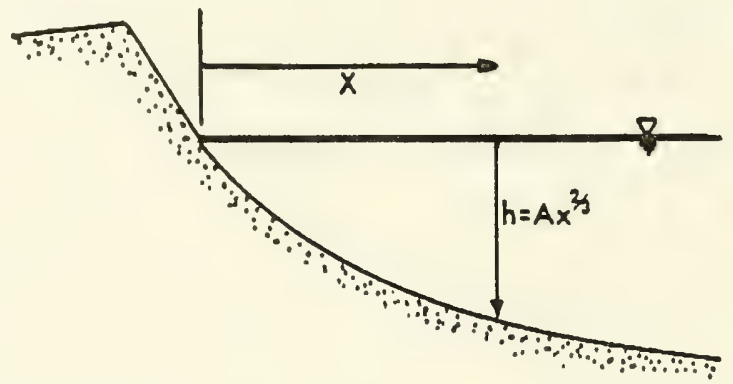

Figure 7. Definition sketch for the equilibrium beach profile (after Kriebel 1982)

30. Dean (1977) gave a plausible derivation leading to Equation 1. He showed that if energy dissipation per unit volume of water in the surf zone were assumed to be the dominant factor controlling profile shape, the twothird power law would result. In addition, the general functional dependence of the shape factor A on the dissipation could be predicted. Dean (1977), Hughes (1978), and Moore (1982) have demonstrated that A depends in a rational way on the grain size or fall velocity of the beach material. A grain size of $0.25 \mathrm{~mm}$ corresponds to a value of A of approximately 0.13 $\mathrm{m}^{1 / 3}$ (Moore 1982). For larger grain sizes, A increases producing a steeper profile, as observed in nature. Figure 8 shows the dependency of $A$ on the grain size according to Moore (1982).

31. In the derivation of Dean (1977), the required energy dissipation is calculated from an assumed linear and constant wave height decay with depth, using small amplitude wave theory. This procedure automatically restricts applicability of the method to a surf zone with spilling breakers for which the breaker height and water depth are linearly related. However, if a smoothing mechanism is posited which slowly shifts sand along the profile, it can be assumed that the equilibrium profile will extend to at least the depth corresponding to the depth of the greatest breaking waves during storms. The smoothing mechanism might simply be the back-and-forth sand movement associated with the wave orbital velocities. 


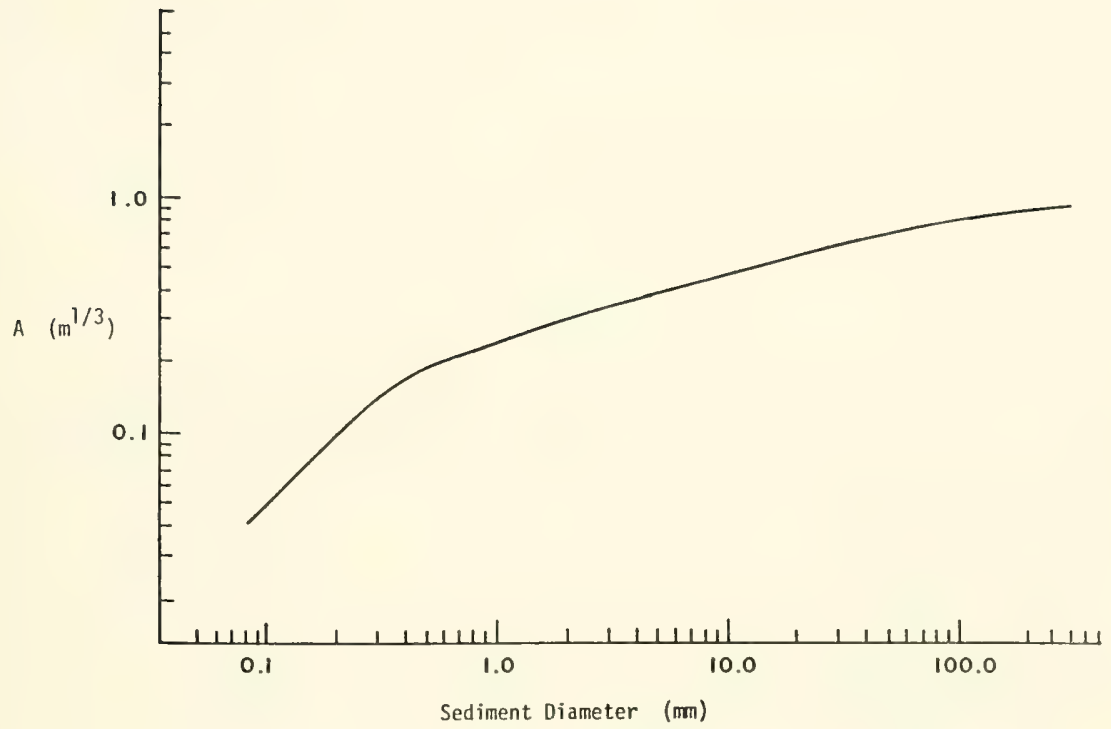

Figure 8. Shape factor A versus sediment diameter (Moore 1982)

32. The equilibrium profile concept is useful for two purposes: it provides a convenient means of visualizing the process of profile change; and, through Equation 1, it provides a reasonable description of the general shape of the beach profile.

\section{Natural Variation in Measured Profiles}

33. As already mentioned, the beach profile is in constant motion under the imposed hydraulic forces which move sediment across and along the shore. The profile thereby undergoes notable short-term macroscale changes (order of days and tens of cubic meters) apart from seasonal and long-term changes. On real and laboratory beaches, these changes do not have perfect symmetry alongshore; there is always some degree of three-dimensionality. This longshore variability may result from the presence of shore protection structures such as jetties or groins, or the variation may be naturally generated by the hydraulic conditions (e.g., by beach cusps or rip currents). Varying geological characteristics along the coast will also produce markedly 
different longshore conditions. In any case, we must quantify the naturally occurring variability in order to establish accuracy requirements for a dune erosion model.

34. Birkemeier, Savage, and Leffler (in preparation) present a large collection of storm erosion data, 46 cases from seven different beach

localities and 13 different storm events (Table 1). Included in the study is

Table 1

Suntery of Storm Data Used to Compute the Varlablility Factor

\begin{tabular}{|c|c|c|c|c|c|c|c|c|c|c|c|c|c|c|c|c|}
\hline \multirow[t]{2}{*}{$\begin{array}{l}\text { Starm } \\
\text { Date }\end{array}$} & \multirow[t]{2}{*}{ Beach } & \multicolumn{2}{|c|}{ Survey Dates } & \multirow{2}{*}{$\begin{array}{c}\begin{array}{c}\text { Nuriber } \\
\text { of } \\
\text { Prof } 11 e s \\
\end{array} \\
\end{array}$} & \multirow[t]{2}{*}{$\begin{array}{l}\text { Surge } \\
\text { Helghtt } \\
\mathrm{m}^{*} \\
\end{array}$} & \multirow[t]{2}{*}{$\begin{array}{l}\text { Return } \\
\text { Perlod } \mathrm{H} \\
\text { yrs } \\
\end{array}$} & $\begin{array}{c}\text { Helght } \\
\text { m }\end{array}$ & $\begin{array}{l}\text { Peek we } \\
\text { Per lod } \\
\text { sec } \\
\end{array}$ & \multirow[t]{2}{*}{$\begin{array}{l}\frac{\text { ave }}{\text { **k }} \\
\begin{array}{c}\text { Dration } \\
r\end{array} \\
\end{array}$} & \multirow{2}{*}{$\begin{array}{l}\text { Medtan } \\
\text { Shoreline } \\
\text { Change } \\
\text { m } \\
0.8\end{array}$} & \multicolumn{2}{|c|}{$\begin{array}{l}\text { Proflle a } \\
\text { Median Hean } \\
\text { Volume Volume } \\
\mathrm{m}^{3} / \mathrm{m} \text { m } \mathrm{m}^{3 / m}\end{array}$} & \multirow[t]{2}{*}{$\begin{array}{l}\text { hanges abov } \\
\text { Proflites } \\
\text { Erosion/ } \\
\text { Accretion } \\
\end{array}$} & \multicolumn{2}{|c|}{$\begin{array}{l}\frac{\text { NGW }}{\text { Range of }} \\
\text { Volume Change } \\
\mathrm{m}^{3} / \mathrm{m}\end{array}$} & $\begin{array}{l}\text { Median } \\
\text { Above } \\
\text { Surgo } \\
\mathrm{m}^{3} / \mathrm{m}\end{array}$ \\
\hline & & Fran & $\frac{\text { To }}{8 \text { Noy } 62}$ & & & & 35 & & & & -110 & -7.4 & & -34.1 & 260 & 79 \\
\hline \multirow{2}{*}{3 Nov 62} & ALLANT & 1 Nov 62 & 9 Nov 62 & 7 & 1.5 & 2.3 & 3.6 & 9.3 & 34 & 9.8 & -9.5 & -7.4 & $5 / 2$ & -3.7 & 8.3 & $\begin{array}{l}-1.9 \\
-4.9\end{array}$ \\
\hline & LUOLAM & 1 Nov 62 & 7 Nov 62 & 19 & 1.5 & 2.3 & 3.7 & 9.3 & 29 & 6.0 & -5.2 & -5.5 & $15 / 4$ & -22.2 & 17.8 & -0.2 \\
\hline \multirow[t]{3}{*}{$6 \mathrm{NOV} 63$} & LBI & 25 act 63 & 15 Nov 63 & 17 & 1.4 & 1.2 & 2.4 & 7.1 & 27 & -3.5 & -1.3 & -5.3 & $20 / 7$ & -59.9 & 12.9 & 1.6 \\
\hline & ATLANT & 28 oct 63 & 14 Nov 63 & 7 & 1.4 & 1.2 & 2.4 & 7.5 & 36 & -14.0 & -25.2 & -42.9 & $6 / 1$ & -150.8 & 0.5 & -8.3 \\
\hline & LLOLAM & 30 oct 63 & 13 Nov 63 & 19 & 1.4 & 1.2 & 2.4 & 7.5 & 26 & -0.7 & -4.4 & -5.1 & $13 / 5$ & -26.3 & 20.0 & -0.6 \\
\hline \multirow[t]{3}{*}{$\sqrt{3} \tan 64$} & LBI & 20 dec 63 & $15 \tan 64$ & 18 & 1.5 & 1.6 & 4.6 & 9.9 & 35 & -0.4 & -28.2 & -20.1 & $17 / 1$ & -69.2 & 6.6 & -16.0 \\
\hline & ATLANT & $31 \mathrm{Dec} 63$ & $17 \operatorname{Jan} 64$ & 4 & 1.5 & 1.6 & 3.7 & 10.3 & 31 & 4.3 & -13.1 & -20.4 & $3 / 1$ & -55.5 & 0.2 & -5.3 \\
\hline & LUOLAM & $7 \tan 64$ & $15 \operatorname{Jan} 64$ & 19 & 1.5 & 1.6 & 4.6 & 10.3 & 35 & -3.7 & -22.2 & -18.2 & $17 / 2$ & -43.3 & 11.5 & -4.6 \\
\hline $16 \operatorname{Sep} 67$ & ATLANT & $15 \operatorname{sep} 67$ & $19 \operatorname{Sep} 67$ & 7 & 1.4 & 1.6 & 2.2 & - & 27 & -0.2 & -15.1 & -8.2 & $5 / 2$ & -41.7 & 38.7 & 0.0 \\
\hline & LUOLA & $14 \operatorname{sep} 67$ & $18 \operatorname{sen} 67$ & 19 & 1.4 & 1.6 & 2.7 & 7.7 & 17 & 4.0 & -6.6 & -8.5 & $13 / 6$ & -61.2 & 28.3 & -0.3 \\
\hline $13 \mathrm{Mar} 68$ & MISQ & $8 \mathrm{Mar} 68$ & $14 \mathrm{Mar} 68$ & 6 & 0.7 & 1 & 3.0 & 8.0 & 25 & -1.0 & -4.3 & -4.4 & $6 / 0$ & -8.0 & -1.2 & -2.9 \\
\hline & WEST & $6 \mathrm{Har} 68$ & $14 \mathrm{Har} 68$ & 11 & 0.7 & $\langle 1$ & 3.0 & 8.0 & 22 & -2.0 & -3.8 & -4.6 & $10 / 1$ & -15.0 & 2.3 & -0.8 \\
\hline & JAES & $11 \mathrm{Mar} 68$ & $18 \mathrm{Kar} 68$ & 15 & 1.2 & $\langle 1$ & 3.0 & 7.4 & 28 & -1.5 & -2.9 & -3.0 & $6 / 3$ & -31.7 & 23.9 & -0.6 \\
\hline & ATLANT & 7 Mer 68 & $13 \mathrm{Mtar} 68$ & 7 & 1.1 & $<1$ & 3.0 & 7.8 & 30 & -3.1 & -3.0 & -2.3 & $4 / 3$ & -18.7 & 13.5 & -0.5 \\
\hline 12 Nov 68 & BI & $2300 t 68$ & 13 Nov 68 & 18 & 1.6 & 8.0 & 2.9 & 7.7 & 28 & -1.4 & -26.4 & -25.0 & $15 / 3$ & -57.0 & 2.4 & -19.6 \\
\hline & ATLANT & 25 oct 68 & 15 NoY 68 & 7 & 1.6 & 8.0 & 2.4 & 6.8 & 22 & -1.8 & -19.7 & -19.4 & $7 / 0$ & -32.1 & -8.1 & -11.1 \\
\hline & LUOLAN & 24 oct 68 & 14 Nov 68 & 19 & 1.6 & 8.0 & 2.8 & 6.8 & 11 & -6.1 & -24.7 & -25.3 & $19 / 0$ & -44.4 & -1.0 & -9.3 \\
\hline 2 Feb 70 & MISQ & $28 \tan 70$ & $4 F E 0$ & 7 & 0.6 & रा & 3.5 & 7.6 & 81 & -2.9 & -7.4 & -7.6 & 770 & -14.5 & -0.8 & -6.2 \\
\hline & JAES & $\bar{V} \operatorname{lan} 70$ & 6 FED 70 & 15 & 1.1 & $\langle 1$ & 2.6 & 8.0 & 23 & -1.3 & 2.6 & 9.2 & $7 / 8$ & -26.3 & 55.4 & 1.6 \\
\hline & ATLANT & $28 \operatorname{lan} 70$ & 4 Feb 70 & 7 & $1.1+$ & - & 2.5 & - & 20 & -6.1 & -8.6 & -6.3 & $6 / 1$ & -12.7 & 10.6 & -2.4 \\
\hline $17 \mathrm{Dec} 70$ & NALSET & $10 \mathrm{Dec} 70$ & $18 \mathrm{Dec} 70$ & 10 & 1.3 & 1.2 & 3.3 & 7.9 & 32 & 0.6 & -20.6 & -20.2 & $9 / 1$ & -48.1 & 22.0 & -6.5 \\
\hline & MISQ & $9 \mathrm{Dec} 70$ & $23 \mathrm{Dec} 70$ & 7 & 1.2 & 1.2 & 4.2 & 9.4 & 30 & -8.0 & -10.5 & -10.0 & $7 / 0$ & -20.0 & -0.1 & -14.8 \\
\hline & WEST & $1 \mathrm{Dec} 70$ & $18 \mathrm{DeC} 70$ & 11 & 1.2 & 1.2 & 3.9 & 9.3 & 34 & 4.3 & -15.5 & -13.0 & $9 / 2$ & -43.2 & 14.8 & -11.5 \\
\hline & Jares & 10 DeC 70 & $20 \mathrm{Dec} 70$ & 15 & 1.6 & 1.2 & 4.0 & 9.4 & 32 & -1.4 & -16.7 & -18.4 & $13 / 2$ & -48.2 & 6.0 & -10.3 \\
\hline & LBI & $7 \mathrm{Dec} 70$ & 18 Dec 70 & 18 & $1.6 t$ & - & 3.5 & 8.9 & 39 & 3.1 & -8.5 & -11.1 & $15 / 2$ & -57.1 & 11.7 & -6.9 \\
\hline & ATLANT & $9 \operatorname{Dec} 70$ & $18 \mathrm{Dec} 70$ & 7 & $1.6 t$ & - & 3.1 & 8.2 & 41 & 3.7 & -15.6 & -1.2 & $4 / 3$ & -27.4 & 61.2 & 0.4 \\
\hline & LUOLAH & $10 \mathrm{DeC} 70$ & $18 \mathrm{Dec} 70$ & 19 & $1.6^{\dagger}$ & - & 2.8 & 9.2 & 33 & -5.1 & -5.2 & -6.5 & $16 / 3$ & -47.2 & 13.3 & -16.1 \\
\hline 19न6 72 & WALSE & $8 F \infty \pi$ & 25 Feb 72 & 10 & 1.9 & $\sim 15$ & 5.1 & 10.4 & 61 & 4.1 & -22.8 & -23.4 & $7 / 3$ & -80.2 & 15.9 & -3.1 \\
\hline & MISQ & $14 \mathrm{Feb} T 2$ & 25 Feb 72 & 7 & 1.5 & 6.0 & 5.5 & 11.4 & 38 & -0.3 & -5.6 & -3.5 & $5 / 2$ & -11.5 & 13.6 & -11.2 \\
\hline & KEST & $5 \mathrm{Fgb} 72$ & 22 Feb $n 2$ & 11 & 1.5 & 6.0 & 5.5 & 10.9 & 44 & -2.2 & -22.8 & -21.6 & $11 / 0$ & -40.0 & -1.1 & -8.3 \\
\hline & JAES & 6 Feb 72 & 24 Feb 72 & 15 & 2.0 & 6.0 & 5.5 & 10.5 & 36 & 0.7 & -14.1 & -10.8 & $12 / 3$ & -36.2 & 27.7 & -4.6 \\
\hline & LBI & 15 Feb 72 & $23 \mathrm{Feb} 72$ & 18 & 1.8 & $\sim 13$ & 4.3 & 9.0 & 52 & 1.7 & -4.0 & -1.1 & $12 / 6$ & -13.9 & 34.3 & -2.7 \\
\hline & ATLANT & 14 Feb $\pi$ & 22 Feb 72 & 7 & 1.8 & $\sim 13$ & 4.3 & 9.0 & 34 & -0.2 & -9.4 & -14.8 & 710 & -45.7 & -5.2 & -1.9 \\
\hline & LUAAH & 16 Feb 72 & 23 Feb $\pi$ & 19 & 1.8 & $\sim 13$ & 4.3 & 9.0 & 56 & 1.5 & -8.4 & -7.8 & $16 / 3$ & -21.0 & 5.1 & -8.5 \\
\hline 17-22 Mar & WUSET & $13 \operatorname{Mar} 73$ & 27 Mar 73 & 13 & 1.2 & (1 & 4.0 & 9.4 & 67 & 2.6 & -5.0 & -9.9 & $6 / 3$ & -49.0 & 13.6 & -9.9 \\
\hline 1973 & WEST & $16 \mathrm{Mar} 73$ & $24 \mathrm{Mar} 73$ & 11 & $1.4 \dagger$ & $\langle 1$ & 4.0 & 9.4 & 52 & -20.2 & -31.4 & -25.8 & $10 / 1$ & -48.9 & 9.9 & -2.6 \\
\hline & JaEs & $12 \mathrm{Mar} 73$ & $25 \mathrm{Mar} 73$ & 15 & 1.4 & $\langle 1$ & 4.1 & 9.9 & 42 & -11.4 & -2.5 & -3.0 & $6 / 4$ & -36.4 & 57.4 & -1.7 \\
\hline & LBI & $14 \mathrm{Mar} 73$ & $25 \mathrm{Mar} 73$ & 17 & 1.3 & 1.0 & 2.6 & 8.2 & 29 & -3.3 & -6.5 & -4.0 & $13 / 4$ & -30.0 & 43.6 & 0.0 \\
\hline & ATLART & $16 \mathrm{Mar} 73$ & $25 \mathrm{Mar} 73$ & 7 & 1.3 & 1.0 & 3.3 & 8.5 & 37 & 11.2 & -3.5 & -11.1 & $5 / 2$ & -58.1 & 13.0 & -5.5 \\
\hline $14 \cot \pi$ & LEI & 13 oct $\pi$ & 15 oct $\pi$ & 9 & 1.8 & 2.0 & - & - & - & 5.0 & -26.2 & -21.9 & $9 / 0$ & -34.6 & -7.9 & -10.3 \\
\hline & LUOLA4 & 11 oct 77 & 16 oct $\pi$ & 13 & 1.8 & 2.0 & - & - & - & -4.7 & -14.8 & -16.2 & $13 / 0$ & -31.2 & -5.1 & -3.0 \\
\hline $190 \mathrm{dec} \pi$ & LE! & $11 \mathrm{Dec} \pi$ & $20 \mathrm{bec} \pi$ & 8 & 1.4 & 1.0 & $3.0 \mathrm{II}$ & - & - & 1.6 & -21.0 & -21.8 & $6 / 0$ & -34.5 & -9.8 & -4.9 \\
\hline & LUDLAM & $10 \mathrm{DeC} \pi$ & $21 \mathrm{DeC} \pi$ & 13 & 1.4 & 1.0 & 2.37 & - & - & -8.6 & -17.6 & -16.7 & $13 / 0$ & -26.5 & -8.9 & -2.1 \\
\hline 6 FEb 78 & LBI & $22 \mathrm{Dec} 77$ & दानक 78 & 9 & 1.7 & 2.6 & - & - & - & -1.4 & -22.3 & -15.9 & $8 / 1$ & -41.4 & 2.6 & -10.5 \\
\hline & HOLAM & 22 Dec $\pi$ & $B$ Feb $\overline{B B}$ & 13 & 1.7 & 2.6 & - & - & - & 2.4 & -3.4 & -5.4 & $9 / 4$ & -32.1 & 9.2 & -0.5 \\
\hline
\end{tabular}

\begin{tabular}{|c|c|c|}
\hline & Locality & Thde gage used \\
\hline NALST & Nauset Beach, Cape Cod, Nass. & Boston Harbar, Mass \\
\hline MISQ & Misquamicut Beach, R.I. & Montack Pt., N.Y. \\
\hline WEST & Westhampton Beach, N.Y. & Montauk Pt., N.Y. \\
\hline JAES & Jones Beach, M.Y. & Sandy Hook, N.J. \\
\hline LBI & Long Beach Is land, N.J. & At lantic City, N.J. \\
\hline ATLANT & Atlantic City, M.J. & At lantic CIty, N.J. \\
\hline LLOAH & Ludlam Beach, N.J. & Atlantic C1ty, H.J. \\
\hline
\end{tabular}

Note: a "-" indicates unknom data.

* - peak surge, measured above NGV.

**. - hindcasted wave helghts at 9m depth.

t - surge data fram Sandy Hook. N.J.

ti - based on visual breaking wave height.

*-gage masurement in 10 -m water depth.

ATLANT Atlantic City, H.J.

At lantic City, N.J. 
a total of 549 different measured profile changes. Though no hurricanes or 100-year events are included, it is a unique data set with which to examine natural variability in profile change.

35. Each case was specifically selected from a larger group of surveys to isolate the effects of single storms. Because all poststorm surveys were conducted within 9 days of the storm, the data contain minimal effects of poststorm beach recovery. For each case, shoreline and volume changes relative to mean sea level (MSL) are computed and presented for a number of beach profile lines.* Birkemeier, Savage, and Leffler (in preparation) also report volume changes based on half-meter contours of elevation. Because the present study is concerned with erosion above the surge level (including the astronomical tide), these data were used to compute the volume changes above the peak measured water level.

36. Also included in Table 1 is the wave height and water level information associated with each storm. The wave data were hindcast according to Jensen (1983). Water level measurements were obtained from nearby tide gages. The peak levels given in Table 1 were computed relative to MSL. Note that because the water level data were not obtained at each beach, a true measure of the local surge and the volume change above the surge level is not available.

\section{Shoreline position}

37. A usual measurement of profile change is the change in shoreline position, which is defined as the MSL intercept. Birkemeier, Savage, and Leffler (in preparation) have found that generally both the MSL shoreline position and the beach slope at MSL are relatively insensitive to storm changes, regardless of locality or storm. For example, of the 549 profilesurvey combinations for which an MSL shoreline change could be computed, 81 percent eroded based on volumetric changes (regardless of magnitude); whereas only 54 percent of the lines had erosional shorelines. Although poststorm recovery (which would affect the shoreline position) is certainly a factor on the 46 percent of the lines which showed shoreline accretion, there is

* The datum used by Birkemeier, Savage, and Leffler (in preparation) is the National Geodetic Vertical Datum (NGVD) of 1929 which is commonly equated to MSL. Since MSL implies a physical land/sea interface, it will be used in place of NGVD. 
considerable evidence indicating that the MSL shoreline position effectively acts as a pivot point.

38. Figure 9 shows the distribution of median shoreline changes by storm and locality. * For each storm and locality, a small "box plot" illustrates the distribution of measured profile changes. The portion of the box above or below the dashed line, respectively, indicates either accretion or erosion. Overall, the average median shoreline change was small, only -0.9 $\mathrm{m}$, with a mean hinge range (difference of the hinges) of $4.8 \mathrm{~m}(+1.7$ to -3.1 $\mathrm{m})$. Median shoreline position changes with an absolute value less than $2 \mathrm{~m}$ were recorded for 39 percent of the cases. Only 8 percent of the shoreline changes had an absolute value greater than $10 \mathrm{~m}$. It is interesting to note that the range of variation between cases (indicated by the heights of the boxes in Figure 9) is relatively small and, with a few exceptions, measured variations are as similar between storms at one locality as they are between localities. Although shoreline position is traditionally used for computing long-term erosion rates, based on this data set use of the change in shoreline position for quantifying storm erosion appears to be limited. Volume changes

39. Figure 10 plots the distribution of volume change above MSL for each locality and storm. Unlike the shoreline changes, the volume changes show more consistent erosion and more variation between storms. Misquamicut and Ludlam Beach had the smallest ranges in variation between profile lines; whereas Nauset Beach and Jones Beach had relatively large ranges. Individual profile change, represented by the extreme values, can be quite large, up to $-150 \mathrm{~m}^{3} / \mathrm{m}$ for one Atlantic City, New Jersey profile. Though it is difficult to intercompare storms, the data in Figure 10 illustrate the large amount of variation which naturally occurs both along a beach and between beaches subjected to the same storm.

40. In order to account for this natural variation caused by storms, the data shown in Figure 10 were used to compute a "variability factor" or

* The median value is preferred over the mean of a number of profile lines because it is insensitive to single profiles with extreme changes and should be more representative of the overall locality change. Plotted changes show both upper and lower extreme values and "hinge" values. Hinge values are defined as the 25 and 75 percentiles for the profiles at each locality. 


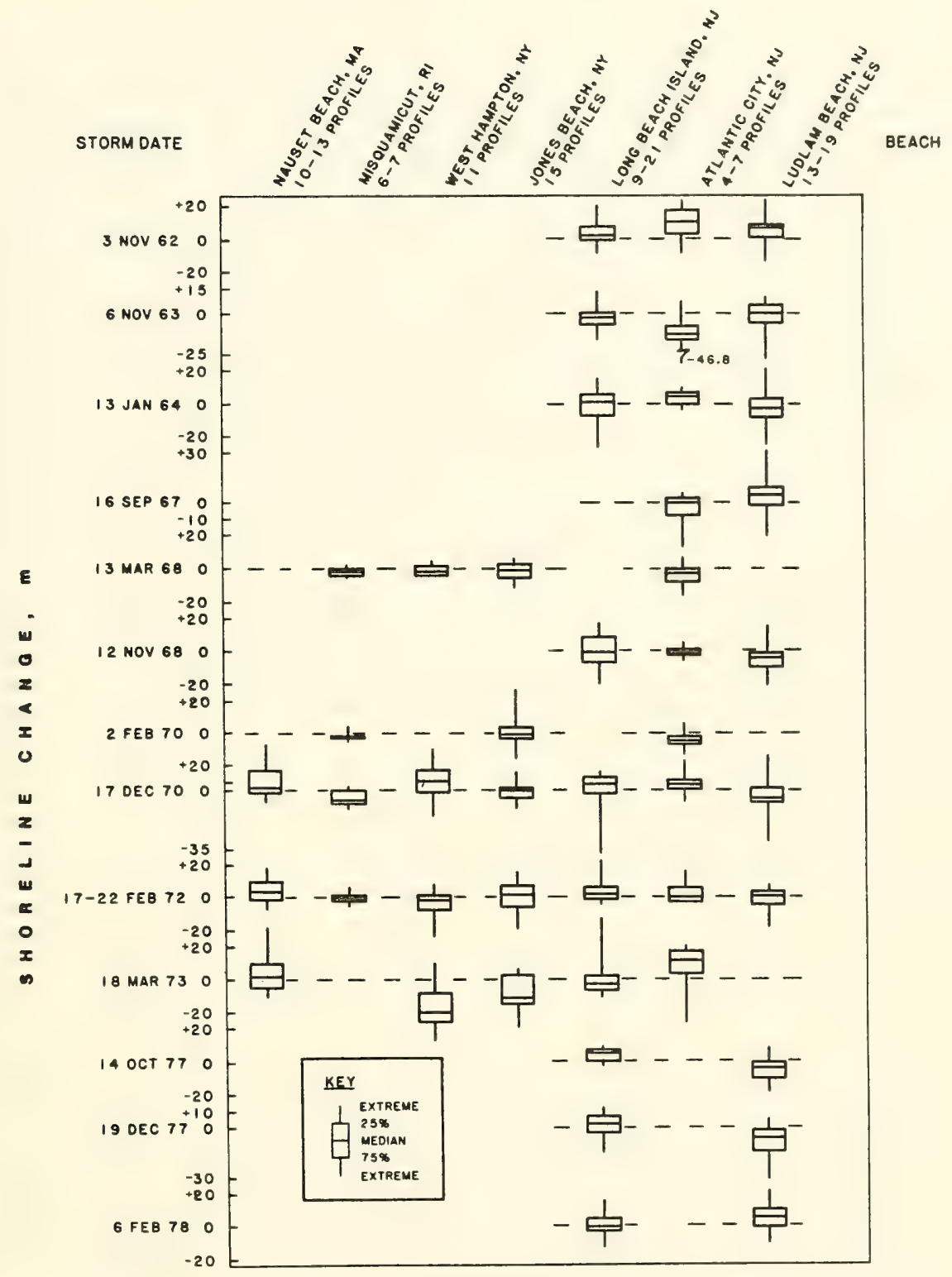

Figure 9. Variation in storm-induced shoreline (MSL) changes computed from a number of profile lines at seven east coast localities 


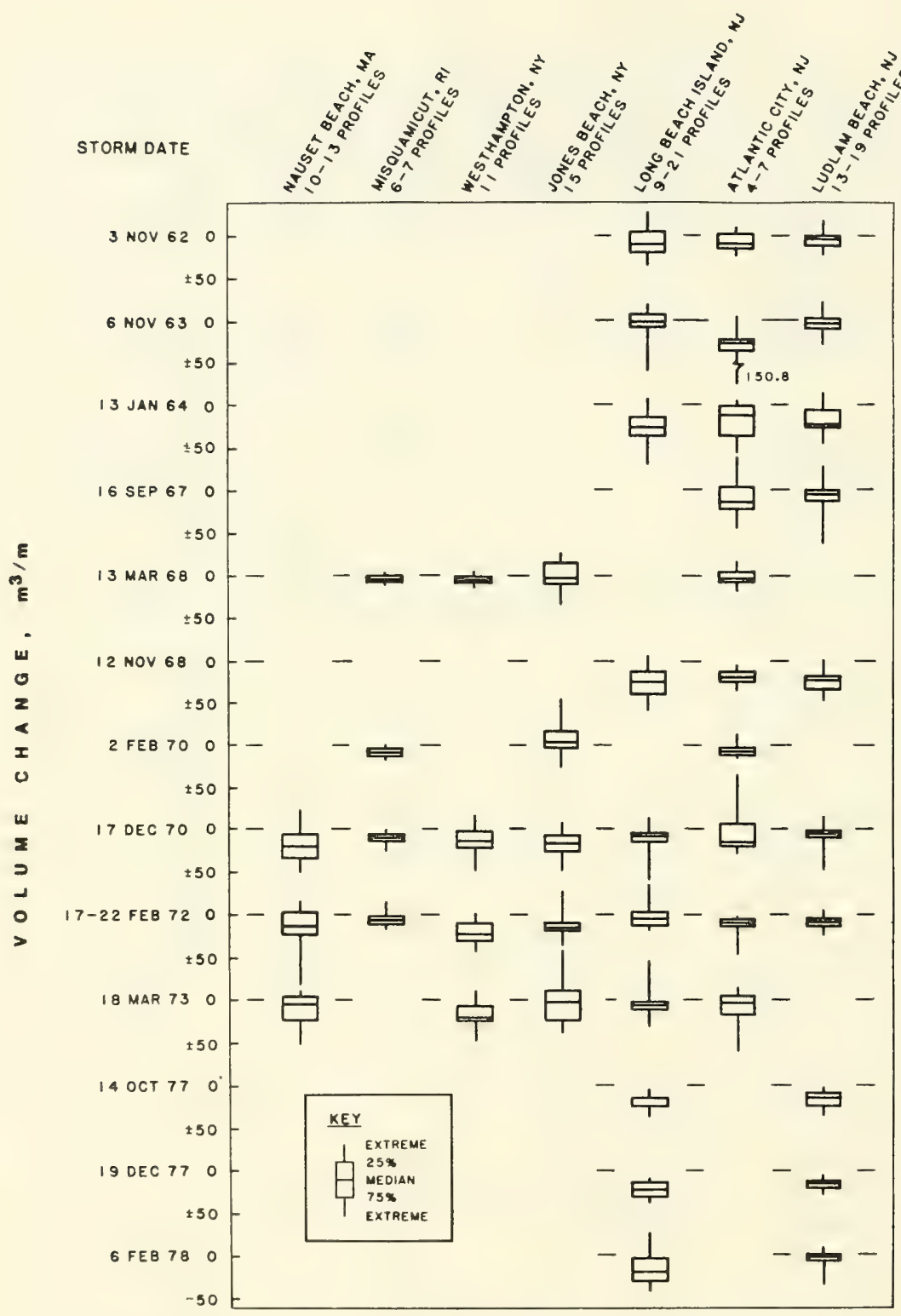

Figure 10. Variation in storm-induced volume changes (above MSL) computed from a number of profile lines at seven east coast localities 
multiplier to be used with a dune erosion estimate. Assuming that the estimate was close to the median volume change on a beach and that a desirable prediction should cover 75 percent of the changes (or any acceptable percentage), then an average multiplier of the median value could be computed to predict the 75 percent change. Of the 45 cases reported by Birkemeier, Savage, and Leffler (in preparation) which had median above-MSL volume losses in excess of $-1 \mathrm{~m}^{3} / \mathrm{m}$ of erosion, a median variability factor of 1.6 was computed and is plotted along with the distribution of factors in Figure 11. Also shown in Figure 11 is a similar distribution of factors based on the computed volume changes above the surge level. Only 35 of the 46 cases given in Table 1 had median above-surge level volume losses in

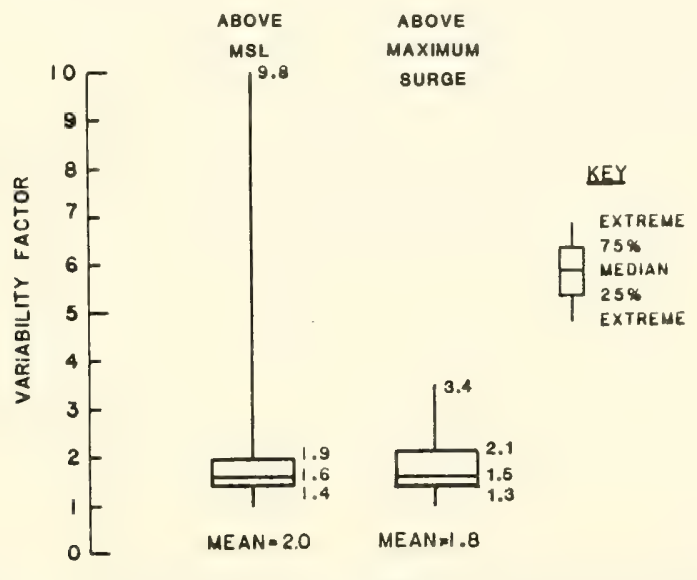

Figure 11. Distribution of computed variability factors

excess of $-1 \mathrm{~m}^{3} / \mathrm{m}$. It is interesting to note that the median above-surge variability factor of 1.5 is nearly identical to the above-MSL factor. Use of the 75 percent factor of 2.1 is recommended. This value can be interpreted as the multiplier of the median required to include volumetric erosion expected on 75 percent of the shoreline. A higher value, for example 2.5, would increase the percentage included and would conservatively account for the uncertainty in the dune erosion estimate. This specific value of the variability factor should be viewed as preliminary, to be revised as more data become available. 
41. In principle, the value of the variability factor could be dependent on surge height, wave height, and the median change. No such dependency was identified in the data analyzed.

42. The need for a variability factor has significant implications relative to the required accuracy of the method. Obviously, with such a high degree of variability, a precise estimate of erosion along an individual profile is not required; however, a reasonable estimate of the maximum (here chosen as the 75 th percentile) change which may occur on any profile is required. An important added consideration is the large degree of uncertainty concerning the long-term stability of a particular beach prior to the arrival of the 100-year storm.

43. Although this report does not address additional requirements introduced by long-term erosion (over periods of many years), the process cannot be ignored. Birkemeier (1979) reported on significant changes resulting from only a 2-year return period storm. The profile shape at any particular time is related to the integrated effect of all previous storm (and nonstorm) waves. Since predictions are invariably based on a limited amount of beach survey data, the accuracy and usefulness of the prediction will decrease with time. As an extreme example, a dune sufficiently substantial to survive a major storm may disappear under the combined attack of a number of small storms over a number of years. The Grand Isle case discussed in Part $I$ is just one example of a scenario repeated along almost every shoreline which is undergoing long-term erosion. 


\section{PART III: PREDICTIVE MODELS OF PROFILE CHANGE AND DUNE EROSION}

44. This section identifies the criteria by which the applicability and suitability of a numerical model for simulating profile change can be judged. The criteria define the properties of an ideal model, one that neither presently exists nor is expected to be developed in the immediate future. The list is given to provide a standard or checklist with which existing profile change models can be evaluated.

45. A dune erosion model need not possess all the properties of a profile change model because a dune erosion model is aimed at simulating an extreme erosion event. The process of beach recovery is assumed to be secondary and can be neglected at the first stage of dune erosion model development. Moreover, as discussed earlier, the accuracy requirements of a model for $V$-zone determination are much less restrictive than those required for an empirical process-response numerical sediment transport model.

Therefore, a subset of the criteria defining the properties of an ideal beach profile model is identified for use in evaluating dune erosion numerical models.

46. Several of the more recent theoretical models of cross-shore sediment transport and beach profile change are briefly described. Then a more detailed evaluation of one of the models is made from the perspective of potential use as a dune erosion model.

\section{Required Characteristics of Beach Profile Change Models}

47. An attempt was made to compile a complete list of properties and characteristics required for an ideal numerical model of profile change, but it is recognized that much has yet to be learned about the processes of wave deformation in the surf zone, beach profile change, dune erosion, and overwash. The individual items or requirements listed below are not completely independent of each other but are presented separately for clarity. These 14 items have been placed into four groups: input data and initial and boundary conditions, calculation procedures, model properties, and extendability. Other combinations of properties are possible also. For example, Dally (1980) and Dally and Dean (1984) have presented five criteria which a "good" beach profile model should satisfy. The four criteria for an 
ideal beach profile change model discussed in this report include the following:

a. Input data, initial conditions, and boundary conditions.

(1) Deepwater wave height and wave period (entering in part as the wave steepness) should be among the basic input variables to drive the model or to establish an offshore wave boundary condition.

(2) The properties of the beach material (fall velocity or representative grain size and composition) must be included. It may be necessary to allow for natural sorting along the profile in some cases.

(3) The profile shape is required as an initial condition.

(4) An offshore boundary condition, specifying the maximum depth to which sand is transported across shore in significant amounts, is required.

(5) An onshore boundary condition is required. This boundary condition must allow for berm and dune erosion, as well as berm buildup.

b. Calculation procedures.

(1) Calculation procedures for the local incident waves, infragravity waves, and wave-induced currents (orbital velocities, mass transport, or undertow) in the region between the offshore and onshore boundary points are required. This calculation includes breaking wave criterion and broken (surf zone) wave model.

(2) The model must allow for calculation or specification of the mean water level, including the effects of astronomical tide, meteorological surge, wave setup, and runup.

(3) Calculation procedures for cross-shore sediment transport rates are necessary. These procedures would include threshold effects and encompass spatially and temporally varying sediment transport regimes over ripples, at the breakpoint, in the sheet flow area, in the swash zone, and at the air-water interface on shore.

(4) A calculation procedure to compute profile change that allows representation of all major morphological features, and which conserves sand volume, is necessary.

c. Model properties.

(1) Formation, movement, and erasure of bars must be represented. 
(2) If the wave conditions and water level are held constant, the model should allow spatially and temporally accurate calculation of both erosional and depositional profiles and produce an equilibrium profile shape.

(3) The model must be verified to produce accurate results for the range of conditions for which it is expected to be applied.

d. Extendability.

(1) Since a deterministic model is not expected to be practicable for field use, the developed model must be compatible with stochastic or probabilistic prediction procedures.

(2) Although as a first step a monochromatic wave input is expected to be adequate, refinements should include the randomness of wave height, direction, and period.

48. The deepwater wave height and wave period are usually available or may be estimated with acceptable accuracy (item a(1)). It is difficult to specify the beach material grain size along the profile as required by a(2). The minimum requirement is knowledge of an average grain size or fall velocity for the target beach. For a(3), in principle, the exact initial profile is required. This information will not be available in a practical situation. Either a historic profile or a representative profile shape will have to be used in applications.

49. For the offshore sediment transport boundary condition (item a(4)), the work of Hallermeier (1979), as modified by Birkemeier (1985b), is probably acceptable at the first stage of modeling. At present, little knowledge exists to formulate a first-principles onshore boundary condition (item a(5)). A rigorous onshore boundary condition will probably incorporate a number of boundary conditions for the foreshore, for the berm, and for the dune. For the present, simple geometrical arguments may have to be used.

50. For item $b(1)$, at present, accurate calculation of the cross-shore current flow through the water column in the surf zone and seaward of the breakers is not possible. Water levels (item b(2)) can be estimated with sufficient accuracy for the purpose of a dune erosion model. The requirement of valid cross-shore sediment transport rate relationships for all regions along the profile (item b(3)) cannot be satisfied by any single formulation or combination thereof presently available. Beach profile change and the sediment transport rate are connected through a continuity 
equation for beach material, and the equation must be properly expressed in numerical form (item $b(4)$ ).

51. Requirement $c(1)$ states that the numerical formulation must be capable of representing all important morphological features. The scheme must produce a profile which is in equilibrium with imposed waves of constant properties $(c(2))$. This requirement is important because it is often possible for a numerical scheme to appear to be stable for a small number of calculation time-steps but will diverge if allowed to continue for a longer simulation interval. This situation implies that the intermediate computed results may be spurious. Naturally, any model must be calibrated and verified by suitable field data (item $c(3)$ ). Only then can it be confidently used for predictions.

52. Concerning the requirement for extension to a probabilistic description (item $d(1)$ ), it has been shown in Part II that a relatively wide range in natural variability exists in beach profile change. In addition, an artificial variability exists because the initial conditions required to set up a numerical model of profile change (wave conditions, initial profile shape, etc.) are not accurately known. The most logical approach would be to calculate a range of values for profile change, within which the actual change would be expected to lie. This approach leads to a stochastic or probabilistic description. For item d(2), it is known that random waves exhibit somewhat different properties from those of monochromatic waves. At a later stage in modeling, the random nature of the wave field should be taken into account as well as sediment transport under random wave action.

\section{Required Characteristics of Dune Erosion Models}

53. A pragmatic engineering simulation model for dune erosion need not possess all the characteristics of a theoretically ideal beach profile change mode1. In this subsection, a subset of parameters, expected to comprise a first-stage dune erosion model, is listed.

a. Offshore wave height and wave period. (Local wave height may or may not be necessary.)

b. Water level, including astronomical tide, meteorological tide, and wave setup. 
c. Representative grain size or fall velocity for the profile.

d. Representative initial shape of the profile, including the dune.

e. Onshore boundary condition(s) for dune erosion.

f. Phenomenological calculation procedure for the cross-shore sediment transport rate or, alternatively, direct calculation of the morphologic change of the profile based on a given idealized form.

g. Calculation procedure for computing dune erosion that contains a temporal dependence.

h. Verification with field data over the range of conditions for which the model will be applied.

The conditions for defining a pragmatic dune erosion model are fewer and considerably less rigorous compared to those defining an ideal beach profile change model.

\section{Numerical Models of Cross-Shore Sediment Transport} and Beach Profile Change

54. This subsection introduces several recent models which might be considered as candidates for developing a "first principles" model of dune erosion. It will be concluded that none of the models can be readily adapted for immediate use as a dune erosion model.

55. The models may be classified into one of two groups according to whether they rely on basic sediment transport equations or on empirical results. Models developed from relations for the cross-shore sediment transport rate include those of Bailard (1981, 1982, 1983, and 1985), Bowen (1980), Dally and Dean (1984), Leont'ev (1985), Moore (1982), and Yang (1981). Empirically based models include those of Swart (1974, 1975, and 1977), Kajima et a1. (1983), and Swain and Houston (1983, 1985). Three models developed specifically for estimating dune erosion and profile change are discussed in Part IV.

Theoretical models

56. The transport rate equations of Bowen (1980) and Bailard (1981, 1982, 1983, and 1985) are based on the energetics approach of Bagnold (1963, 1966). Both contain provisions to calculate bed load and suspended load 
sediment transport. Bowen's model has not been developed further than the initial formulation. Bailard (1985) states that the performance of his model was "disappointing" in a comparison of predicted and measured profile change. Bailard's work is described in the next subsection. Dally and Dean (1982) developed a beach profile numerical model by assuming mean wave-induced flows are responsible for the sediment transport. Only suspended load was considered. Leont'ev (1985) uses an energetics-based approach and assumes bed-load transport is directed solely onshore; whereas suspended load is directed solely offshore. Mean flows are calculated. Yang's (1981) model employs both mean and fluctuating currents, and the suspended load (no bed load is included) is assumed to be transported only offshore. Moore (1982) uses an equilibrium profile-based transport model plus a surf zone wave model.

57. It is remarkable that despite quite different assumptions, all of the above mentioned models were demonstrated by the authors to represent beach profile change to some extent. Notably, in the development of the cited models, little discussion was given to the onshore and offshore boundary conditions and to the approach to equilibrium. Also, only very limited verification data were employed. In particular, no comparison was made to data on the sediment transport rate but only to profile change. In order to further explore these models, it is useful to examine one of them, Bailard's sediment transport model, in detail.

Sediment transport model of Bailard

58. Bailard (1981) derived equations for both longshore and crossshore sediment transport on an assumed idealized beach of constant slope. The model is based on the energetics approach of Bagnold (1963, 1966). Bowen (1980) presented a similar model. Since the model of Bailard has undergone refinement and testing (Bailard 1982, 1983, and 1985), Bailard's work was selected for closer examination, and discussion will be limited to the crossshore component. It should be mentioned that Bailard's work mainly concerns the theoretical derivation and interpretation of a general sediment transport rate equation, although the transport rate formulas were applied in a "2-1ine" numerical model (Bailard 1985) in which the profile is characterized by two contours.

59. The transport model of Bailard (1981) generalized Bagnold's steady-state energetics-based stream model to account for time-varying flow 
and an arbitrary sloping bottom. In the energetics stream approach, it is assumed that the rate of sediment transport is proportional to the rate of energy dissipation of the "stream," which for the coastal case is the energy loss caused by the decay of broken waves and by bottom friction.

60. Bailard's formula is an algebraic expression consisting of two terms intended to describe transport contributions from bed load and suspended load. Empirical efficiency factors enter for both bed and suspended load; these factors express the capability of the stream to move the sediment. The transport equation also contains the sediment fall velocity (in the suspended load term), the local beach slope, the internal angle of friction of the sediment (for bed load), and higher moments of the wave orbital velocity. (In the general case in which longshore transport is included, the equation contains longshore components of the steady and unsteady wave and wave-induced currents.) The wave height and period enter through the wave orbital velocities.

61. Bailard (1982, 1983), who applied his transport equation to calculate profile change observed in the field, reported disappointing results, finding that the model accounted for only 19 percent of the observed variance in the measured beach volume change. He noted that actual beach profile change is difficult to calculate directly from sediment transport rates because the net transport is a small difference resulting from two large (onshore and offshore) transport rates. The required moments of the wave orbital velocity cannot presently be calculated from existing wave theory with any confidence. In fact, the orbital velocities of commonly used small amplitude theory are symmetric and would yield no net transport at a given location. A wave theory suitable for describing surf zone waves has not yet been developed. Bailard used empirical moment estimates obtained from current meter records. These instruments and records may not be sufficiently accurate for the intended purpose (Aubrey and Trowbridge 1985).

62. In summary, the transport equation of Bailard is relatively sophisticated and ambitious in describing many of the physical processes, but its applicability has not been demonstrated. In addition, despite its sophistication, the sediment transport equation still relies on empirical parameters (efficiencies, moments, and friction factor), and requires knowledge of quantities which are difficult to calculate. As with the other models introduced above, the onshore boundary condition has not been 
investigated to the same level as the sediment transport rate for the subaqueous profile. We also note that the energetics approach may not be applicable seaward of the wave breaker line.

63. At present, no theoretical model of beach profile change or dune erosion exists which can be applied for engineering purposes now or in the immediate future. Considerably more theoretical and numerical groundwork must be laid. Little is known about the onshore boundary condition required for such models. In addition, sediment transport rate predictive equations would be best evaluated by comparison to sediment transport rate data and not solely by comparison to the resultant beach profile change. 
64. The earliest shoreline retreat model was proposed by Bruun (1962) who postulated that the profile would rise and shift landward, without changing shape, in response to a rising sea level. The Netherlands has always been concerned with storm effects and dune erosion, and Edelman (1968, 1972) proposed the first dune erosion model based on a simple change in profile slope and a balance of eroded to deposited material. Modified Edelman approaches have been used by Vallianos (1975), Tetra Tech (1983), and by Hill and Herchenroder (1985).

65. Recent research efforts have resulted in two models which are currently being used for engineering studies. Based on a series of largeand small-scale laboratory tank tests, limited field data, and theoretical work, the Dutch have improved and refined the Edelman approach (Vellinga 1983b, 1986 and van de Graaff 1983) and are using it in the design of artificial dunes in The Netherlands. At nearly the same time, a numerical model of beach and dune erosion based on the equilibrium profile equation was developed by researchers at the University of Delaware and the University of Florida and reported in a series of theses (Kriebel 1982 and Moore 1982), papers (Kriebel and Dean 1985a,b and Kriebel 1986), and reports (Chiu and Dean 1984 and Kriebel and Dean 1985c). The model has been widely used to estimate dune erosion in Florida (Chiu and Dean 1984, Kriebel 1984a,b, and Kriebel 1986). Both of these models, which will be referred to as the "Vellinga" and "Kriebel" models, have been shown to produce reasonable dune erosion estimates. A third model, the MSBWT model developed by Balsillie $(1984 \mathrm{c})$, is also being used by the state of Florida for erosion estimates. In this section, these three models will be described, and the relative merits of each will be discussed.

\section{The Vellinga Model}

66. Because much of their country is below MSL, the Dutch have long considered the building of dikes, dunes, and other coastal structures of primary importance. Vellinga (1983b, 1986) presents a complete discussion of the most recent Dutch method. A probabilistic approach to dune design using the model has been reported by van de Graaff $(1983,1986)$. Sargent and 
Birkemeier (1985) discuss use of the model and present a computer program for making the computations. Bruun (1984) and Vellinga (1984) address specific aspects of the model, including the possibility of a universal erosion profile shape for both sand and rock beaches. Vellinga (1984) also compares the profile shape equation developed for the Dutch method to the equilibrium equation used by the Kriebel model (Equation 1).

\section{Governing equations}

67. Figure 12 is a schematic cross section of the predicted Vellinga

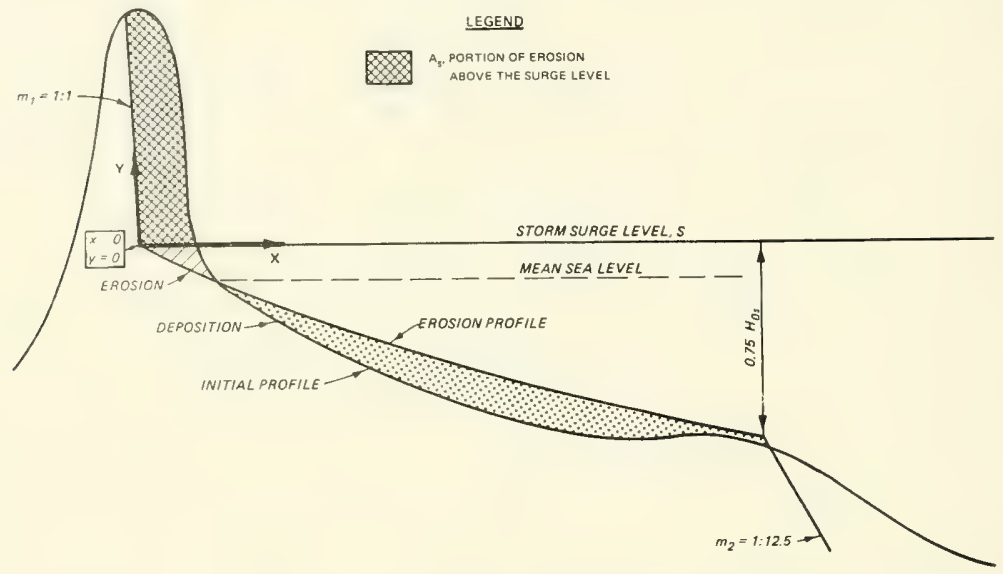

Figure 12. Schematic representation of the Vellinga predicted profile (Vellinga 1983b)

storm profile. The shape of the erosion profile is based on the following equation:

$$
y(x)=0.47(x+18)^{0.5}-2
$$

where $x$ is the seaward distance in meters from the foot of the poststorm dune $(x=0, y=0)$ and $y$ is the depth below the surge level in meters. This equation is based on model profiles (generated with irregular waves) and has been derived for "reference storm" conditions with a deepwater wave height $\mathrm{H}_{\mathrm{OS}}$ of $7.6 \mathrm{~m}$, a wave period $T$ of $12 \mathrm{sec}$, and a median grain size of $0.225 \mathrm{~mm}$. The tests simulated a duration of $5 \mathrm{hr}$ with a constant water depth at the storm surge level. This 5-hr duration is typical of the fast 
moving North Sea storm surges and is one of the limiting assumptions of the model if intended for general use.

68. The equation is applied to a distance 200 to $250 \mathrm{~m}$ seaward of the shoreline. From the scale relationships used in the model studies, Equation 2 can be generalized in terms of $\mathrm{H}_{\mathrm{OS}}$ and fall velocity $\mathrm{w}$ as

$$
-y=\frac{2.0-0.47\left[x\left(\frac{7.6}{H_{\text {oS }}}\right)^{1.28}\left(\frac{w}{0.0268}\right)^{0.56}+18\right]^{0.5}}{\left(\frac{7.6}{H_{\text {os }}}\right)}
$$

where $x, y$, and $H_{O S}$ are in meters and $w$ is in $\mathrm{m} / \mathrm{sec}$. The profile defined by Equation 3 terminates offshore at

$$
x=250\left(\frac{\mathrm{H}_{\text {OS }}}{7.6}\right)^{1.28}\left(\frac{0.0268}{w}\right)^{0.56}
$$

which, substituting into Equation 3, yields

$$
y=0.75 \mathrm{H}_{\mathrm{OS}}
$$

69. Constant slopes are used to terminate the profile at the shoreward end $\left(m_{1}\right.$ at $\left.x=y=0\right)$ and seaward end $\left(m_{2}\right)$ of Equation 3 and are defined as

$$
\begin{gathered}
\mathrm{m}_{1}=-1: 1 \\
\mathrm{~m}_{2}=-1: 12.5
\end{gathered}
$$

Use of this steep poststorm dune face $m_{1}$ is consistent with field observations, and $\mathrm{m}_{2}$ is arbitrarily fixed in agreement with model tests.

70. Application of Equation 3 is straightforward. Based on the wave height and fall velocity, a profile shape is computed. The origin of this line, with the two end slopes is placed at the surge level and shifted horizontally landward until the eroded volume equals the deposition. In order to compensate for longer duration storms, Vellinga (1983b) suggests 
that the erosion volume (above the surge level) be increased by 5 to 10 percent for each hour (over 5) that the storm surge is within $1 \mathrm{~m}$ of the peak surge level (with a maximum increase of 50 percent). This suggested increase is based on the results of long duration model tests with constant surge level.

71. Note that as a result of the simplicity of Equation 3, the poststorm profile shape is dependent only on the prestorm profile, wave height, surge level, and grain size. After a storm passes, only a larger storm, with a higher surge level, will cause additional erosion. The model is based on the assumption that the profile adjusts to equilibrium and that all sediment movement is in the offshore direction (no gradients in longshore transport and no overwash). The model does not account for the formation and movement of bars and, in fact, Vellinga (1983b) noted that the model overpredicted the erosion for model tests with offshore bars.

72. Despite these limitations, the model has been shown to produce reasonable dune erosion estimates (Ve11inga 1983b, 1986, and Sargent and Birkemeier 1985). Based on all available model and field data (Figure 13),

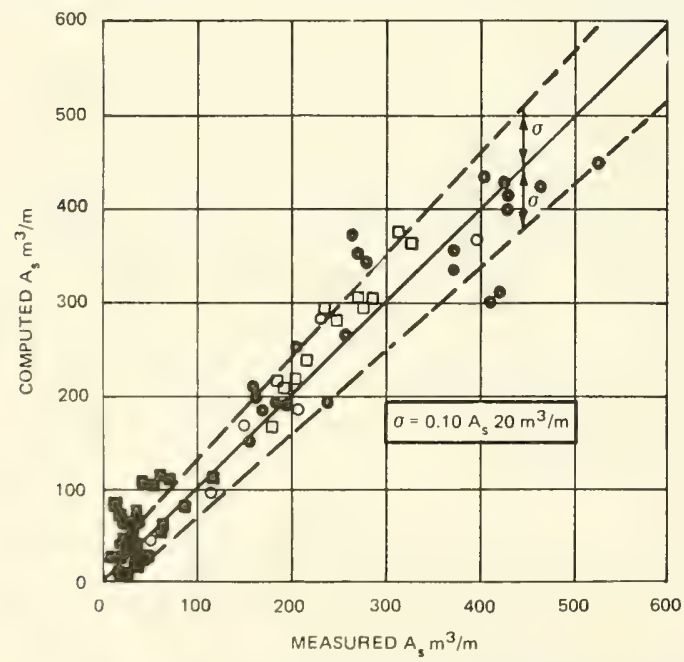

\section{LEGEND}

- model tests, scale series

D MODEL TESTS, VARIABLE HYDRAULIC CONDITIONS

- LARGE-SCALE TESTS, VARIABLE HYDRAULIC CONDITIONS

- FIELD MEASUREMENTS 1976 - STORM SURGE

Figure 13. Predicted volume changes above-surge level versus measured laboratory and field data (Vellinga 1983b)

Vellinga (1983b) specifies the standard deviation of the predicted, abovesurge level, eroded volume $A_{S}$ as 


$$
\sigma_{A_{S}}=\left(0.10 A_{s}+20\right) \mathrm{m}^{3} / \mathrm{m}
$$

This relationship indicates that the model was developed and is most useful for large storms producing above-surge level erosion quantities in excess of $100 \mathrm{~m}^{3} / \mathrm{m}$, a relatively large quantity if compared to published data on eroded volumes along United States' coasts. For example, using above-MSL quantities, only one of the storms given in Table 1 caused in excess of 100 $\mathrm{m}^{3} / \mathrm{m}$ of erosion. Similarly, in reports by Balsillie (1985c, 1985d) which document the effect of Hurricane Elena and a severe northeaster on the State of Florida, the largest single profile change, above MSL, was $119 \mathrm{~m}^{3} / \mathrm{m}$. Most changes were considerably less, as were the above-surge changes.

\section{Properties of the Vellinga model}

73. In this section the specific properties of the Vellinga model, as they relate to the requirements of a dune erosion model given in Part III, are addressed.

a. Deepwater wave height is included both in the equation of the predicted profile and in the offshore termination point. On the basis of the model tests, wave steepness had limited effect on the erosion quantity. The model is applicable for wave steepnesses between 0.02 and 0.04 (Vellinga 1983).

b. The model requires specification only of the peak surge level. The time-history of the water level is not required. Wave runup and setup are not included. The duration of the storm is indirectly simulated.

c. The shape of the predicted profile is dependent on the fall velocity of the median grain size; the native slope is not directly included.

d. The actual prestorm profile shape is used. This profile allows features such as berms and bars to be accounted for in the balance between erosion and deposition. However, the required specification of the true prestorm profile is a disadvantage because the shape of the profile prior to the 100-year storm will not be known.

e. A realistic $1: 1$ slope is assumed for the eroded dune from the surge level up. This slope is consistent with field measurements of nearly vertical beach and dune scarping. The dune foot is specified at the surge level, which is consistent with data from Balsillie (1985a). Vellinga (1983b) indicates that field data have shown variation of the dune foot from 0.5 to - 
$0.5 \mathrm{~m}$ relative to the surge level. The model does not predict berm recovery.

f. Because the model is based on an assumed equilibrium of the poststorm shape, the rate of transport is not directly

specified. Conservation of sediment is satisfied by requiring that deposition balance erosion.

g. An equilibrium profile is computed under the assumption of a 5-hr storm surge duration. Longer durations are treated indirectly. This approach correctly assumes that most of the upper beach and dune erosion takes place during the time of peak surge.

h. The shape of the poststorm profile has been verified by model tests at a number of different scales and for field profiles recorded after the Dutch storm surge of 1953 (Vellinga 1983b). Sargent and Birkemeier (1985) have also demonstrated applicability of the model for modeling erosion caused by minor storms in the United States.

74. Although the Vellinga model lacks a detailed description of sediment transport and is limited to cross-shore transport on sandy beaches with dunes, as will be shown in Part V, it is easy to apply and does provide reasonable estimates of dune erosion. Its major disadvantage for use on United States' beaches is the lack of a duration factor. The method is expected to underestimate dune erosion caused by long duration northeasters. In addition, a poststorm profile shape of almost fixed form limits the applicability of the procedure since it prevents the method from working on mildy sloping (flat) beaches. (It was found to be impossible to balance the erosion and deposition.)

\section{The Kriebel Model}

75. The Kriebel model is based on the equilibrium profile concept originated by Bruun (1954) and further investigated, extended, and verified by Dean (1977), Hughes (1978), Hughes and Chiu (1981), and others. The equilibrium beach profile concept is discussed in Part II. The fundamental assumption of the model is that the profile is shaped by uniform energy dissipation per unit volume of breaking and broken waves in the surf zone. By this principle, the model is limited to describing the evolution of the subaqueous beach profile from the swash zone to the breaker zone (Figure 2 ). 
Because of a singularity (described below), the equilibrium principle cannot be applied at the shoreline; the equilibrium concept-based portion of the model must be terminated some distance seaward of the water's edge. Ad hoc geometrical-based assumptions are employed to simulate profile change in the swash zone and on the beach face and dune. Despite these apparent severe limitations, the Kriebel model has been demonstrated to yield qualitatively and quantitatively reasonable results (Kriebel 1982, 1986).

Governing equations

76. The following discussion is based on the work of Dean (1977), Kriebel (1982), Moore (1982), and Kriebel and Dean (1985a,b). The two reports by Kriebel ( $1984 \mathrm{a}, \mathrm{b})$ are recommended for a more complete discussion. The fundamental assumption is that the beach profile is well approximated by the following relationship:

$$
h(x)=A x^{b}
$$

which is the general power law form of Equation 1. As discussed in Part II, the most appropriate value of the scale coefficient $b$ is $2 / 3$, which can be explained by uniform energy dissipation (Dean 1977). However, use of a variable exponent, although highly empirical, results in better fits to some profiles (Balsillie 1982). The best fit scale coefficients determined in this manner do not deviate greatly from the value of $2 / 3$. The shape parameter A was empirically related to the mean grain size (Figure 8 ) by Moore (1982). Moore recommended that A be represented by a smooth line drawn through somewhat scattered results to give a monotonically increasing function of grain size. This relationship expresses the well-known result that coarse-grained beaches tend to be steeper than fine-grained beaches.

77. The basic equation for the cross-shore transport rate $Q_{c}$ per unit beach width is assumed to be given by

$$
Q_{C}=k\left(D-D_{e q}\right)
$$

where

$$
\begin{aligned}
\mathrm{k}= & \text { empirical coefficient } \\
\mathrm{D}= & \text { energy dissipation per unit volume (assuming spilling waves) } \\
\mathrm{D}_{\text {eq }}= & \text { energy dissipation corresponding to the equilibrium } \\
& \text { profile for a beach of given grain size }
\end{aligned}
$$


Operationally, the spilling wave assumption means that the wave height of breaking and broken waves is proportional to the local water depth, using a fixed constant of proportionality. With the $x$-axis directed offshore as shown in Figure 7, offshore transport has a positive sign, and onshore transport has a negative sign. After manipulations, the dissipation $D$ is ultimately expressed in the form

$$
D=\operatorname{const}\left(h^{1 / 2} \frac{\partial h}{\partial x}\right) \text {. }
$$

in which const is the product of known constant factors. The empirical coefficient $k$ was found to have the value $2.2 \times 10^{-6} \mathrm{~m}^{4} / \mathrm{N}$ (Moore 1982) based on the results of profile change found in the large-scale flume experiments of Saville (1957).* From Equations 10 and 11, it is seen that if the depth is greater than the equilibrium depth at a given location, sand will move offshore, i.e., erosion is associated with the higher water levels which would occur during a storm.

78. It is noted that wave height and wave period do not explicitly enter in the transport rate equation. The water level (the depth $h$ ) is seen to be the main external force determining the cross-shore transport rate. The wave height is indirectly included in the transport equation since it is used to determine the location of the breaker depth or width of the surf zone over which the model acts.

79. Beach profile change is put into time-dependent form by inserting the transport rate predictive formula, Equation 10, into the beach material (sand) continuity equation expressed in the form

$$
\frac{\partial x}{\partial t}=-\frac{\partial Q_{c}}{\partial h}
$$

in which $t$ is time. Equation 12 can be numerically solved if the surge hydrograph, initial profile, and offshore wave height and period are given. The hydrograph describes the water level as a function of time and must be either predicted by another numerical model or be specified from measurements.

* Kriebel (1986) recalibrated his revised model using data from Saville (1957) and determined that $k$ should equal $8.7 \times 10^{-6} \mathrm{~m}^{4} / \mathrm{N}$. 
80. If Equation 10 is inserted into Equation 12, one term results with an exponent of the depth $h$ as $-1 / 2$. This quantity is singular at the shoreline where $h=0$. Therefore, in practice, the equilibrium profilebased portion of the model is terminated at some finite water depth and connected to another model which operates landward of the connection point. The Kriebel model uses simple geometrical and volume conserving procedures in this landward section. In particular, a linear beach face slope is smoothly connected with the equilibrium profile at the depth where the beach face slope equals the slope of the equilibrium profile for the given water level conditions. In the version of the model evaluated in Part $V$ (Kriebel 1984a,b), two options are permitted for simulating dune erosion: one allows representation of a wide, flat berm and the other a sloping beach that directly connects to a dune. Kriebel (1986) includes a more realistic wave runup limit, the formation of an erosional scarp, and a more realistic, nearly vertical eroded dune face.

Properties of the Kriebel model

81. The Kriebel model satisfies a number of the criteria developed in Part III for judging the quality of a dune erosion model. A critical discussion will now be given based on general properties of the model.

a. Wave height and period do not explicitly appear in the model. The wave height is used only in the determination of the wave breaking point, hence the width of the surf zone. These important parameters effectively disappear because of the basic assumptions of the model, i.e., equilibrium profile, shallow-water approximations to small amplitude wave theory, and the spilling wave breaker assumption. Since wave steepness or another criterion is not used to specify whether erosion or accretion will occur, the model may predict erosion when actually accretion or recovery would occur for the given wave and beach conditions.

b. The model requires specification of the water level through time which it uses in a time-stepping manner. Both storm duration and water level enter through the characteristics of the hydrograph.

c. The model accounts for grain size or fall velocity through the scale parameter A. Values of A were determined empirically and thus can be used with relative confidence.

d. The initial profile is not required, although it can be used if available. This is both a potential advantage and disadvantage. On the one hand, an initial profile will 
probably not be accurately known, so that use of a schematic profile is convenient. On the other hand, beach erosion is expected to be sensitive to the initial profile configuration, including the presence of a bar.

e. The onshore boundary condition is based on simple geometrical considerations. It does not accurately reproduce poststorm profile shapes. A more sophisticated onshore boundary condition is desirable.

E. A highly schematic but very reasonable expression is used to model the cross-shore sediment transport rate. Although not based on fundamental physical principles, it appears to be well suited for engineering applications. The sediment continuity equation is used to calculate profile change and dune erosion. It is limited to cross-shore transport, and the only major features modeled are dune and berm erosion and change of an assumed equilibrium-shaped profile.

g. The model time-steps through the storm hydrograph toward an equilibrium form. This time-dependent capability is an important property of the model since it allows both long and short duration storms to be modeled.

h. The model has been demonstrated to give reasonable results in a limited number of comparisons to measured dune erosion volumes. A more detailed discussion of this point is given in Part V.

82. The Kriebel model is judged to provide a reasonable means to estimate dune erosion which is compatible with the expected quality of the input data. The model requires as input the beach grain size; an initial profile if available or, instead, an assumed schematic profile; the surge hydrograph; and the deepwater wave height. The model does not allow for bar formation; therefore, the recovery process is not well described. Similarly, sediment transport seaward of the breaker line is not taken into account.

83. Although not discussed in detail here, the Kriebel model could be modified to allow for inundation. In principle, the model could also be extended to describe erosion of seawal1-backed dunes. Such a model is currently undergoing testing at CERC and is found to perform favorably. 
84. The MSBWT model (Balsillie 1984c) resulted from a series of investigations of breaking wave properties (Balsillie 1984a,b) in order to estimate the height of storm waves crossing low-1ying inland areas.

Recently, the erosion process has been added to the model, and it is now used to estimate storm effects on nonflooded, flooded, and breached profile types (Balsillie 1985b).

\section{Governing equations}

85. The MSBWT model is based on a combination of the physics of surf zone wave dynamics and statistical estimates of unknowns such as erosion quantities and bar/trough shapes. The basic assumption of the wave transformation model is that energy in the surf zone is not uniformly dissipated but is dissipated through the breaking and reformation of incident waves (a more realistic assumption). Breaking waves are required to be plunging breakers. This is more appropriate than the spilling wave assumption, since waves typically break by plunging on most coasts of the United States.

86. The model is based on the assumption of an initial equilibrium profile shape for the offshore and uses the actual beach shape. Beginning with the surge height (including wave setup), a design wave period, and a $20-\mathrm{ft}(6-\mathrm{m})$ wave, waves in $1-\mathrm{ft}(0.3 \mathrm{~m})$ high increments are propagated shoreward. At computed plunge points, an offshore bar and trough are formed, the shapes of which are determined by the statistical analysis of bar/trough data for the depth of the particular breaker.

87. Since the bars form from the convergence of sediment both from offshore and onshore, a net deficit of material exists at the trough of the innermost bar. The depth of this trough, plus an additional depth based on the depth of bed liquefaction, is used to generate a poststorm profile shape extending up to the surge level. Similar to the Vellinga model, a 1:1 slope is assumed for the face of the poststorm dune (above the surge level).

88. The eroded volume is separately computed based on the following dimensional (metric) equation (Balsillie, 1985a, 1986): 


$$
Q_{e} \text { avg }=\frac{1}{1665}\left(g^{1 / 2} t_{r} s^{2}\right)^{4 / 5}
$$

where

$$
\begin{aligned}
Q_{e} \text { avg }= & \text { average erosion for a particular area, } \mathrm{m}^{3} / \mathrm{m} \\
g= & \text { acceleration of gravity, } \mathrm{m} / \mathrm{sec}^{2} \\
t_{r}= & \text { rise time (the time required to reach the peak surge } \\
& \text { level), sec } \\
\mathrm{S}= & \text { peak storm surge, } \mathrm{m}
\end{aligned}
$$

The data from the 10 cases used to determine this equation show a remarkable linear fit (Figure 14). This equation is interesting because it relates the final erosion quantity only to the surge level and the rise time rather

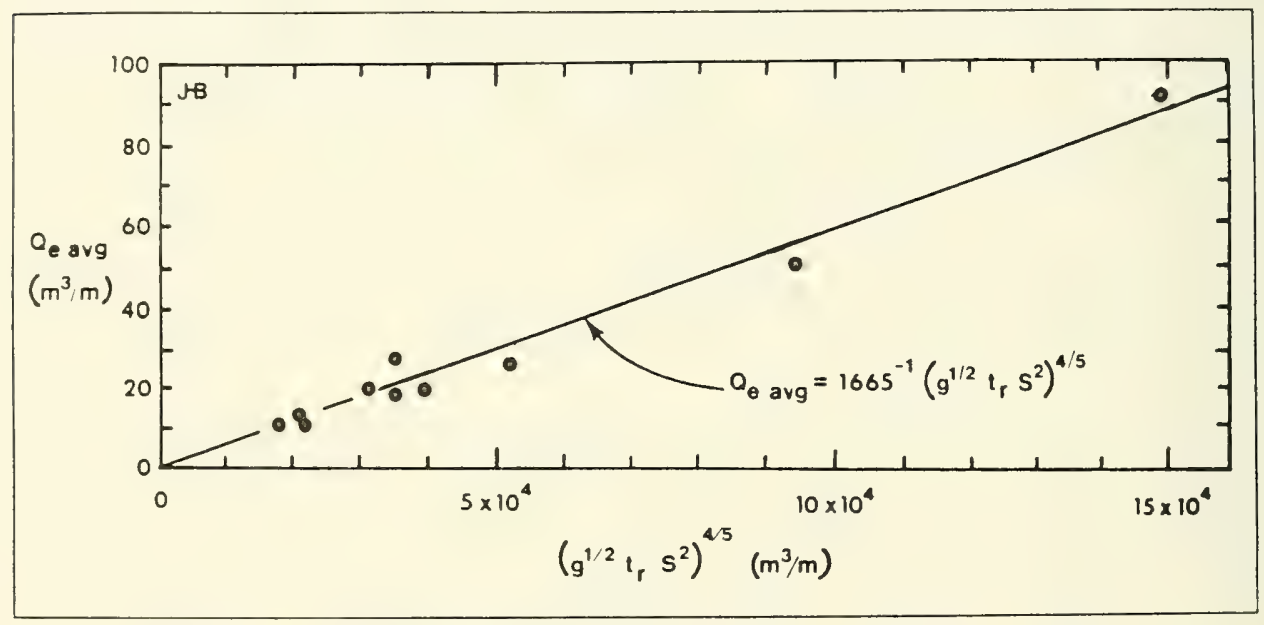

Figure 14. Relationship between measured average net erosion $Q_{e}$ avg and the factor $\left(g^{1 / 2} t_{r} s^{2}\right)$ (Balsillie 1986)

than to grain size, beach slope, offshore features, or wave height. Unlike the Kriebel and Vellinga models, since the profile does not adjust to equilibrium based on a balance between erosion and deposition, successive similar storms will produce the same amount of erosion. As in the Vellinga model, the peak surge is most important. The duration is incorporated through use of the rise time, which correctly reduces the erosion potential of fast moving storms.

89. Since for a particular purpose the model of Balsillie (1985a) was 
used to predict the 92.5 percentile of erosion, the following equation is used:

$$
Q_{e} \max =\frac{1}{808}\left(g^{1 / 2} t_{r} s^{2}\right)^{4 / 5}
$$

Once the erosion quantity is determined from Equation 13 (or Equation 14), the poststorm shape is moved along the surge level until the eroded area equals the estimate.

90. Because the MSBWT model is designed to predict the average (or maximum) erosion for a particular area, it was verified (Balsillie 1985b) by comparing actual and predicted poststorm profile shapes to 32 cases where measured changes were within $1.5 \mathrm{~m}^{3} / \mathrm{m}$ of the actual $Q_{e}$ avg. In addition, damage to three piers (two in Florida, one in California) was correlated to the maximum wave crest elevation predicted by the model.

Properties of the MSBWT

91. This section relates the properties of the MSBWT model to the 1ist of requirements for dune erosion models stated in Part III.

a. The deepwater wave height and period entered are required by the wave transformation model in order to determine the depth of the innermost trough. Wave steepness is included through use of a surf parameter defined as the wave steepness divided by the square root of the beach slope (Balsillie 1984c).

b. The model requires input of the maximum surge level above the still-water line, including the wave setup.

c. The effect of grain size is included only as it affects the offshore slope and the predicted equilibrium poststorm shape.

d. The actual beach profile shape is fitted to an equilibrium offshore shape. The true shape of the offshore is not required.

e. The onshore boundary is dependent on the type of profile (nonflooded, flooded, or breached). Each is treated differently. On nonflooded profiles, a $1: 1$ slope is used for the eroded dune above the surge level.

f. Cross-shore transport is modeled through the volumetric requirements of bar formation. The model has provisions for accounting both dune erosion and overwash. Volume losses are 
determined by an independent equation so that sand volume is not conserved.

g. The wave transformation model is not time dependent; it assumes that the offshore bar-trough bathymetry is in equilibrium. The erosion model includes time dependency through use of the rise time of the surge level.

h. The model has been tested for a range of Florida and gulf coast profile changes and found to produce reasonable results. The volumetric relationship (Equations 13 and 14 ) is based on a limited number of data points but from a wide range of Florida and non-Florida beaches.

92. The MSBWT model has evolved from a surf zone wave transformation model to a combined wave and beach profile erosion model. Because the model includes a description of many of the important processes associated with dune erosion, further testing and evaluation should be made, particularly with respect to non-Florida, non-gulf coast beaches. Several considerations preclude use of the MSBWT at present. Although numerous reports document various aspects of the model, a report by Balsillie (in preparation) detailing the present model in use by the state of Florida has not been published. Though the code for the model has been published (Balsillie 1984c), it is written in the Applied Programming Language, a computational programing language which is seldom encountered in coastal research. Conversion of the complex code to FORTRAN or PASCAL would be time consuming and costly. Finally, the model and the equations and assumptions on which it is based must pass the scrutiny of independent testing and verification. 
PART V: EVALUATION OF THE VELLINGA AND KRIEBEL MODELS

93. Both the Vellinga and Kriebel models are highly empirical in their conception and formulation. However, empirical modeling techniques have been proven to be capable of predicting certain extremely complex natural phenomena, such as dune erosion. These predictions can be reliable if

a. The modeling parameters have been carefully selected for a particular site.

b. The model results have been properly interpreted in a manner consistent with the assumptions and simplifications inherent in the model formulation.

c. The modeled area and storm event do not significantly deviate from the conditions for which the model was formulated and tested.

94. Since a certain amount of interpretative skill and engineering judgment are required for use of both the Vellinga model and the Kriebel model, a quantitative comparison of the two models was made to demonstrate their capabilities. Sargent and Birkemeier (1985) used a number of individual beach and offshore profiles for each of four storms to demonstrate the accuracy of the Vellinga model. In this section, the Kriebel model is applied to these same data and compared both to the Vellinga model results and to measured changes. The comparison is based on only 14 points. A more rigorous evaluation with a wider variety of data, though desirable, was beyond the scope of this feasibility study.

\section{Field Data}

95. The storm data used by Sargent and Birkemeier (1985) are summarized in Table 2. Deepwater wave data were either obtained from 3-hr wave hindcasts (Jensen 1983) in $9 \mathrm{~m}$ of water (Westhampton), from gage measurements in comparable water depths (Duck), or estimated from visual breaking wave observations (Long Beach Island). Surge heights (without wave setup or runup) were computed from water level measurements collected by the nearest available sensors. Sediment fall velocities were determined from representative sediment grain size data from each beach.

96. The severity of each of the four storm events used in the comparison was quantified by both pre- and poststorm profile surveys, including 
Table 2

Storm Events

\begin{tabular}{|c|c|c|c|c|c|}
\hline Location/Date & $\begin{array}{l}\text { Duration* } \\
\mathrm{hr}\end{array}$ & $\begin{array}{l}\text { Surge Level } \\
\text { m above MSL }\end{array}$ & $\begin{array}{l}\text { Wave Ht } \\
\text { m }\end{array}$ & $\begin{array}{l}\text { Fall vel } \\
\mathrm{m} / \mathrm{sec}\end{array}$ & $\begin{array}{l}\text { Number of } \\
\text { Profiles } \\
\end{array}$ \\
\hline $\begin{array}{l}\text { Westhampton, N.Y. } \\
3 \text { Feb } 1972\end{array}$ & 6.0 & 1.3 & 4.3 & 0.0450 & 3 \\
\hline $\begin{array}{l}\text { Westhampton, N.Y. } \\
19 \text { Feb } 1972\end{array}$ & 7.0 & 1.5 & 5.5 & 0.0450 & 3 \\
\hline $\begin{array}{l}\text { Long Beach Is, N.J. } \\
19 \mathrm{Dec} 1977\end{array}$ & 9.0 & 1.4 & 3.0 & 0.0450 & 5 \\
\hline $\begin{array}{l}\text { Duck, N.C. } \\
14 \text { Nov } 1981\end{array}$ & 15.5 & 1.6 & 4.0 & 0.0500 & 3 \\
\hline
\end{tabular}

* This is duration as defined by the Vellinga model, the elapsed time the surge level was within $1 \mathrm{~m}$ of the peak level.

either actual (Duck) or approximate offshore data, at several locations. Note that these data were originally selected to satisfy the requirements of the Vellinga model with respect to dune height, width, and slope. This data set was further analyzed in order to derive the input conditions required for use of the Kriebel model. This analysis involved approximating the modeled area by defining a constant dune and berm height, dune and berm face slopes, and berm width. The offshore profile was approximated as monotonically increasing in depth according to the equilibrium profile concept.

97. The resulting approximations for the geometry of each of the surveyed profiles which were used as input for the Kriebel model are presented in Table 3. The value of the shape coefficient A for each of the profiles was selected to best represent the prestorm offshore profile. Since the majority of the profiles are characterized by bar formations, the resulting equilibrium profile represents a smoothing of the existing offshore bathymetry.

98. An additional parameter required by the Kriebel model is the surge hydrograph, the duration of which differs from that defined by the Vellinga model. The period used for this application represents the duration of the entire storm surge event; whereas the duration used for the Vellinga model only represents the maximum peak. Therefore, the durations shown in Table 3 are much longer than those of Table 2 . 
Table 3

Geometric Input Data

Kriebel Model

\begin{tabular}{|c|c|c|c|c|c|c|c|c|}
\hline \multirow[b]{2}{*}{ Location/Date } & \multicolumn{3}{|c|}{ Dune } & \multicolumn{3}{|c|}{ Berm } & \multirow[b]{2}{*}{$\mathrm{m}^{\mathrm{A} / 3}$} & \multirow[b]{2}{*}{$\begin{array}{c}\text { Duration } \\
\mathrm{hr}\end{array}$} \\
\hline & $\begin{array}{l}\text { Prof ile } \\
\text { Number }\end{array}$ & $\begin{array}{l}\text { Height } \\
\mathrm{m}\end{array}$ & Slope & $\begin{array}{c}\text { Width } \\
\mathrm{m}\end{array}$ & $\begin{array}{l}\text { Height } \\
\text { m }\end{array}$ & Slope & & \\
\hline \multirow{3}{*}{$\begin{array}{l}\text { Westhampton } \\
3 \text { Feb } 1972\end{array}$} & 3 & 5.8 & 0.174 & 4.0 & 3.4 & 0.083 & 0.124 & 60 \\
\hline & 4 & 4.7 & 0.070 & 3.7 & 2.0 & 0.065 & 0.114 & 60 \\
\hline & 5 & 4.7 & 0.098 & 18.0 & 2.0 & 0.105 & 0.075 & 60 \\
\hline \multirow{3}{*}{$\begin{array}{l}\text { Westhampton } \\
19 \text { Feb } 1972\end{array}$} & 3 & 5.6 & 0.138 & 0.0 & 2.4 & 0.066 & 0.108 & 60 \\
\hline & 4 & 4.6 & 0.157 & 0.0 & 1.8 & 0.040 & 0.117 & 60 \\
\hline & 5 & 8.4 & 0.151 & 10.0 & 2.7 & 0.051 & 0.128 & 60 \\
\hline \multirow{5}{*}{$\begin{array}{l}\text { Long Beach } \\
\text { Is land } \\
19 \text { Dec } 1977\end{array}$} & 14 & 5.5 & 0.340 & 0.0 & 2.6 & 0.086 & 0.114 & 96 \\
\hline & 15 & 4.3 & 0.175 & 0.0 & 2.3 & 0.078 & 0.113 & 96 \\
\hline & 16 & 5.3 & 0.156 & 4.9 & 2.0 & 0.087 & 0.114 & 96 \\
\hline & 17 & 5.0 & 0.333 & 0.0 & 3.1 & 0.081 & 0.118 & 96 \\
\hline & 18 & 5.3 & 0.130 & 2.4 & 2.0 & 0.109 & 0.124 & 96 \\
\hline \multirow{3}{*}{$\begin{array}{l}\text { Duck } \\
14 \text { Nov } 1981\end{array}$} & 186 & 7.5 & 0.210 & 0.0 & 1.7 & 0.046 & 0.105 & 72 \\
\hline & 188 & 6.6 & 0.203 & 0.0 & 2.4 & 0.079 & 0.101 & 72 \\
\hline & 190 & 6.4 & 0.500 & 0.0 & 4.0 & 0.107 & 0.101 & 72 \\
\hline
\end{tabular}

\section{Mode1 Comparison}

99. Above-MSL and above-surge level erosion quantities predicted by the Vellinga and Kriebel models for each profile line are given in Table 4. Note that as recommended by Vellinga, his prediction has been adjusted for the duration of the storm, which in most cases improves the result. Although there is considerable scatter in the data (Figure 15), the volumetric estimates are deemed reasonable. The worst case for both models, Profile 18 on Long Beach Island, is an isolated case which probably resulted from the location of this profile near a large terminal groin. For the 14 cases, the Vellinga model tends to equally over- and underpredict the above-MSL changes but underpredicts all but two of the above-surge level quantities. The Kriebel model tends to overpredict both quantities.

100. Poststorm profile shapes are not as accurately reproduced. Cross-section plots for all the cases are shown in Figure 16. Note that because only the poststorm profile shapes from the Kriebel model are shown in Figure 16, they appear misleading with respect to the conservation of sand. Figures $17 \mathrm{a}$ and $\mathrm{b}$ illustrate the schematic initial and predicted profile shapes used with the Kriebel model for both the best and worst fits given in Table 4 .

101. The data presented in Table 4 indicate that both models are 
Table 4

Measured and Predicted Erosion Quantities*

\begin{tabular}{|c|c|c|c|c|c|c|c|c|c|c|c|c|c|}
\hline \multirow[b]{3}{*}{$\begin{array}{c}\text { Location/ } \\
\text { Date }\end{array}$} & \multirow[b]{3}{*}{$\begin{array}{l}\text { Prof ile } \\
\text { Number }\end{array}$} & \multicolumn{6}{|c|}{ Erosion Above MSL } & \multicolumn{6}{|c|}{ Erosion Above Peak Surge Level } \\
\hline & & \multirow[b]{2}{*}{ Actual } & \multicolumn{2}{|c|}{ Vellinga Model } & \multicolumn{3}{|c|}{ Kriebel Model } & \multirow[b]{2}{*}{ Actual } & \multicolumn{3}{|c|}{ Vellinga Model } & \multirow{2}{*}{$\begin{array}{l}\text { Kriebel } \\
\text { Predicted }\end{array}$} & \multirow{2}{*}{$\begin{array}{l}\text { Model } \\
\text { Percent } \\
\text { Actual }\end{array}$} \\
\hline & & & Predicted & Adjusted & $\begin{array}{l}\text { Percent } \\
\text { Actual } \\
\end{array}$ & Predicted & $\begin{array}{l}\text { Percent } \\
\text { d Actual }\end{array}$ & & Predicted & Adjusted & $\begin{array}{l}\text { Percent } \\
\text { Actual }\end{array}$ & & \\
\hline Westhampton & 3 & 52.8 & 38.5 & 41.1 & 78 & 29.5 & 56 & 18.2 & 14.2 & 15.6 & 86 & 20.3 & 112 \\
\hline \multirow[t]{2}{*}{3 Feb 1972} & 4 & 69.4 & 11.6 & 12.2 & 18 & 23.0 & 33 & 42.6 & 2.3 & 2.5 & 6 & 10.2 & 24 \\
\hline & 5 & 51.3 & 37.9 & 39.8 & 78 & 32.3 & 63 & 33.8 & 15.6 & 16.4 & 49 & 19.2 & 57 \\
\hline Westhampton & 3 & 26.5 & 43.0 & 47.3 & 178 & 33.9 & 128 & 15.3 & 13.7 & 15.1 & 99 & 24.8 & 162 \\
\hline \multirow[t]{2}{*}{19 Feb 1972} & 4 & 35.2 & 10.5 & 11.6 & 33 & 19.1 & 54 & 8.5 & 0.2 & 0.2 & 2 & 9.2 & 108 \\
\hline & 5 & 37.1 & 20.5 & 22.6 & 61 & 21.1 & 67 & 17.1 & 2.6 & 2.9 & 17 & 7.7 & 45 \\
\hline Long Beach & 14 & 30.6 & 26.2 & 31.4 & 103 & 38.2 & 125 & 17.6 & 9.1 & 10.9 & 62 & 22.6 & 128 \\
\hline Is land & 15 & 26.2 & 27.6 & 33.1 & 126 & 42.5 & 162 & 18.2 & 8.9 & 10.7 & 59 & 30.8 & 169 \\
\hline \multirow[t]{3}{*}{$19 \mathrm{Dec} 1977$} & 16 & 13.8 & 25.8 & 31.0 & 224 & 35.2 & 255 & 8.0 & 5.9 & 7.1 & 89 & 16.3 & 204 \\
\hline & 17 & 34.5 & 27.4 & 32.9 & 95 & 43.4 & 126 & 20.0 & 7.7 & 9.2 & 46 & 33.6 & 168 \\
\hline & 18 & 6.0 & 20.8 & 25.0 & 416 & 41.7 & 695 & 0.0 & 7.3 & 8.5 & - & 29.0 & - \\
\hline Duck & 186 & 31.7 & 20.6 & 30.9 & 97 & 32.7 & 103 & 10.1 & 3.0 & 4.5 & 45 & 23.1 & 229 \\
\hline \multirow[t]{2}{*}{14 Nov 1981} & 188 & 41.3 & 34.5 & 51.8 & 125 & 48.1 & 112 & 18.5 & 13.6 & 20.4 & 110 & 37.8 & 204 \\
\hline & 190 & 37.4 & 44.0 & 66.0 & 176 & 53.7 & 143 & 19.3 & 20.3 & 30.5 & 158 & 44.9 & 233 \\
\hline
\end{tabular}

* Quantities in $\mathrm{m}^{3} / \mathrm{m}$.

** Adjustment based on an additional 5 percent per hour over $5 \mathrm{hr}, 50$ percent maximum.

Kriebel Model

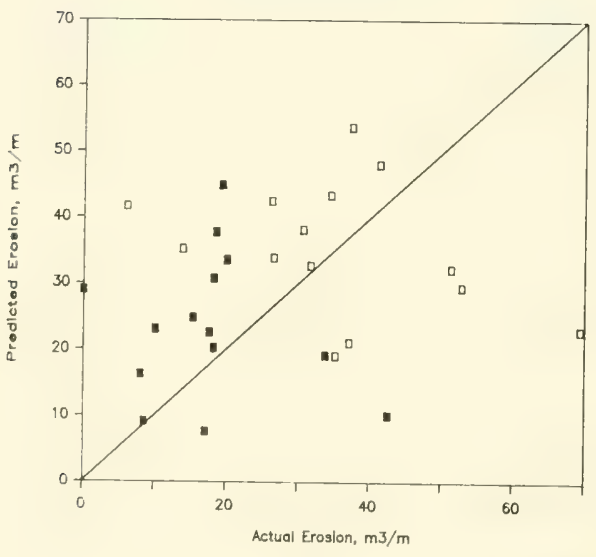

D Above-uSL Change:
Vellinga Model

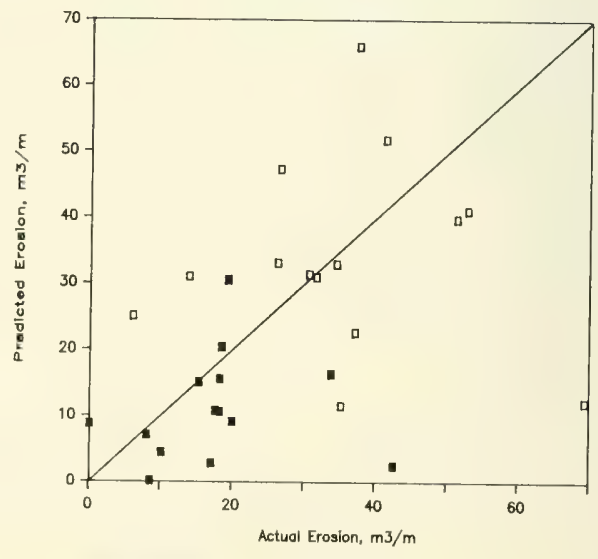

- Above-surge Lovel

Figure 15. Actual and computed volume changes for the Kriebel and Vellinga models 

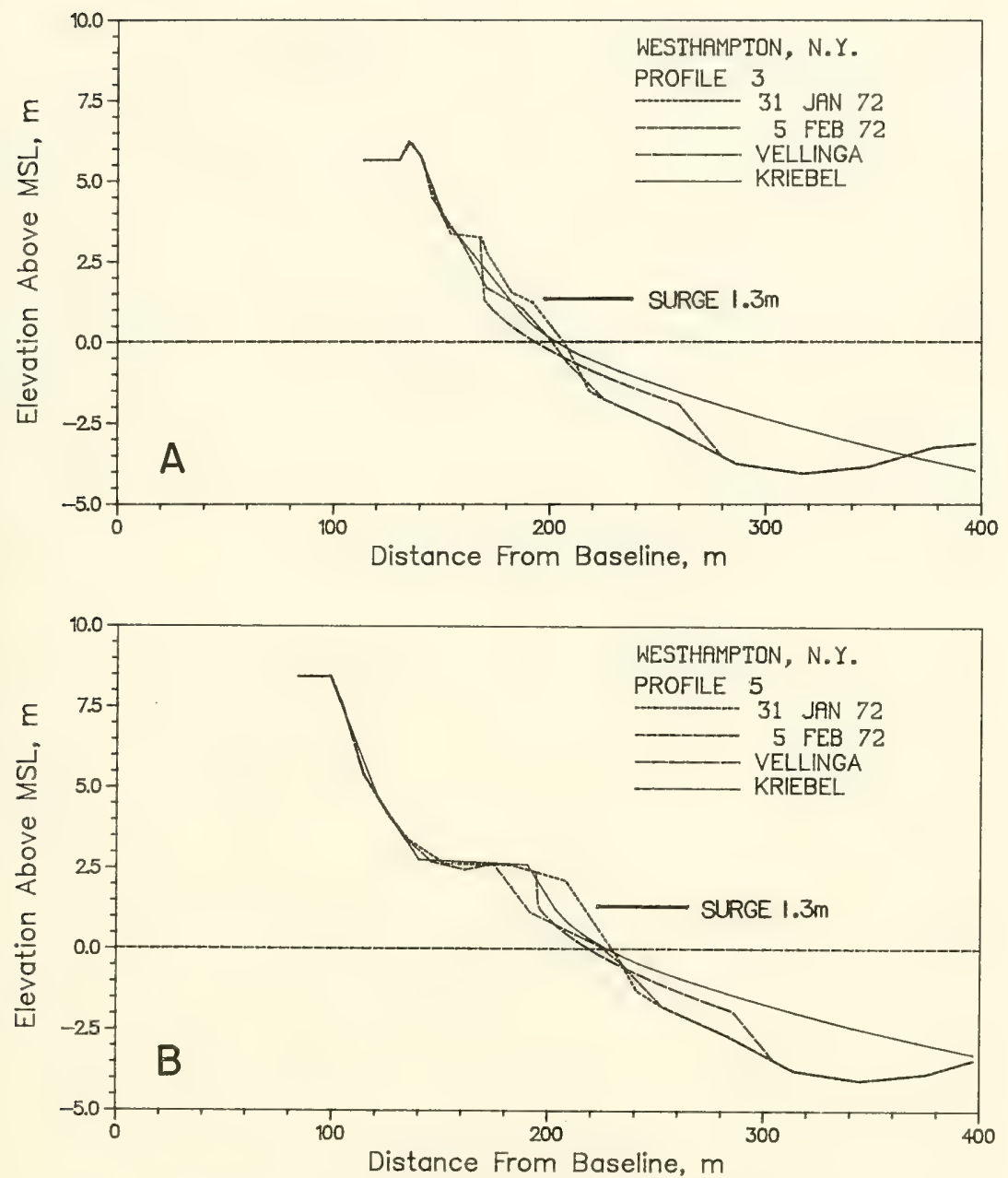

Figure 16. Measured and predicted profile data used in the evaluation of the Kriebel and Vellinga models (Sheet 1 of 7 ) 

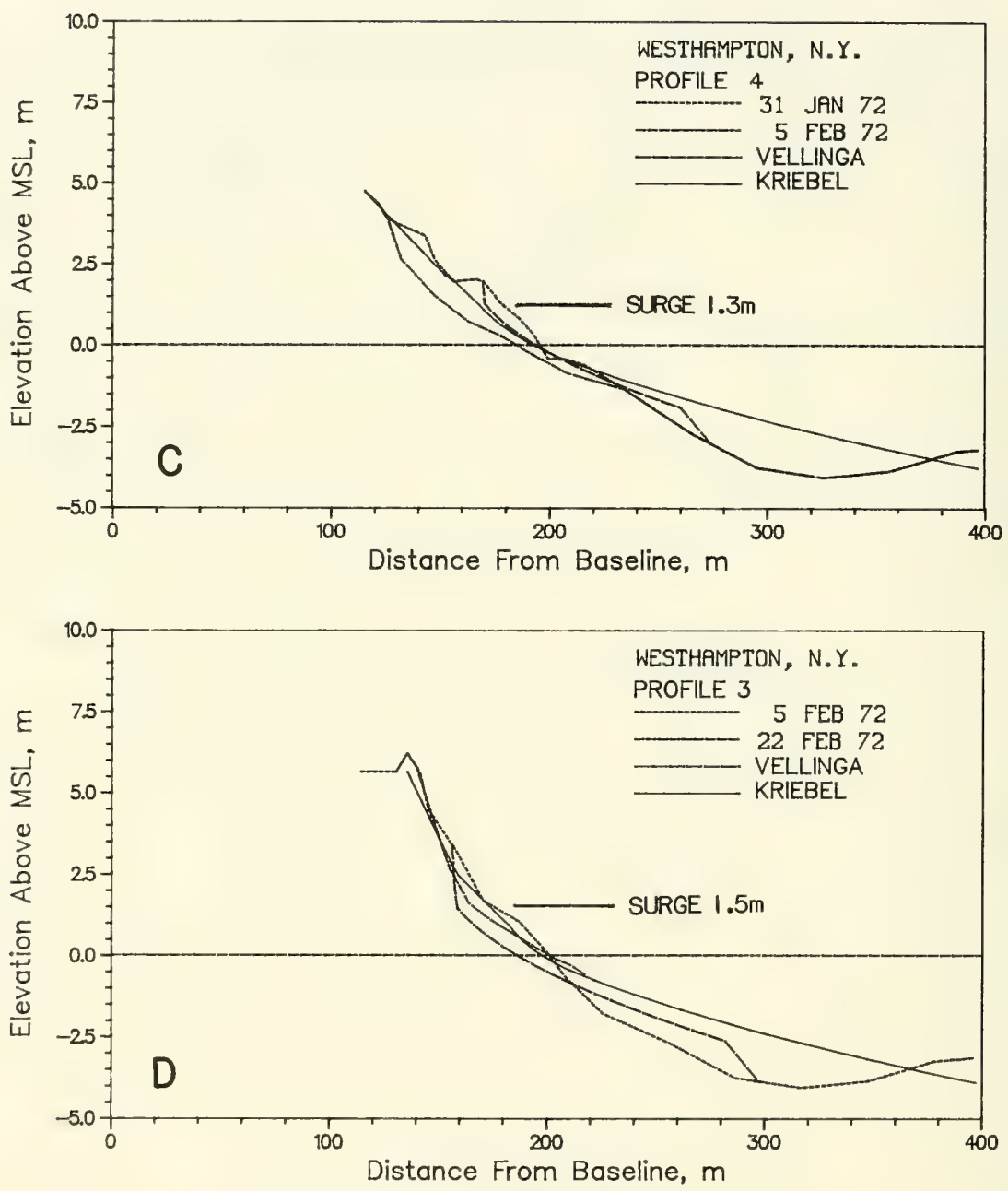

Figure 16. (Sheet 2 of 7) 

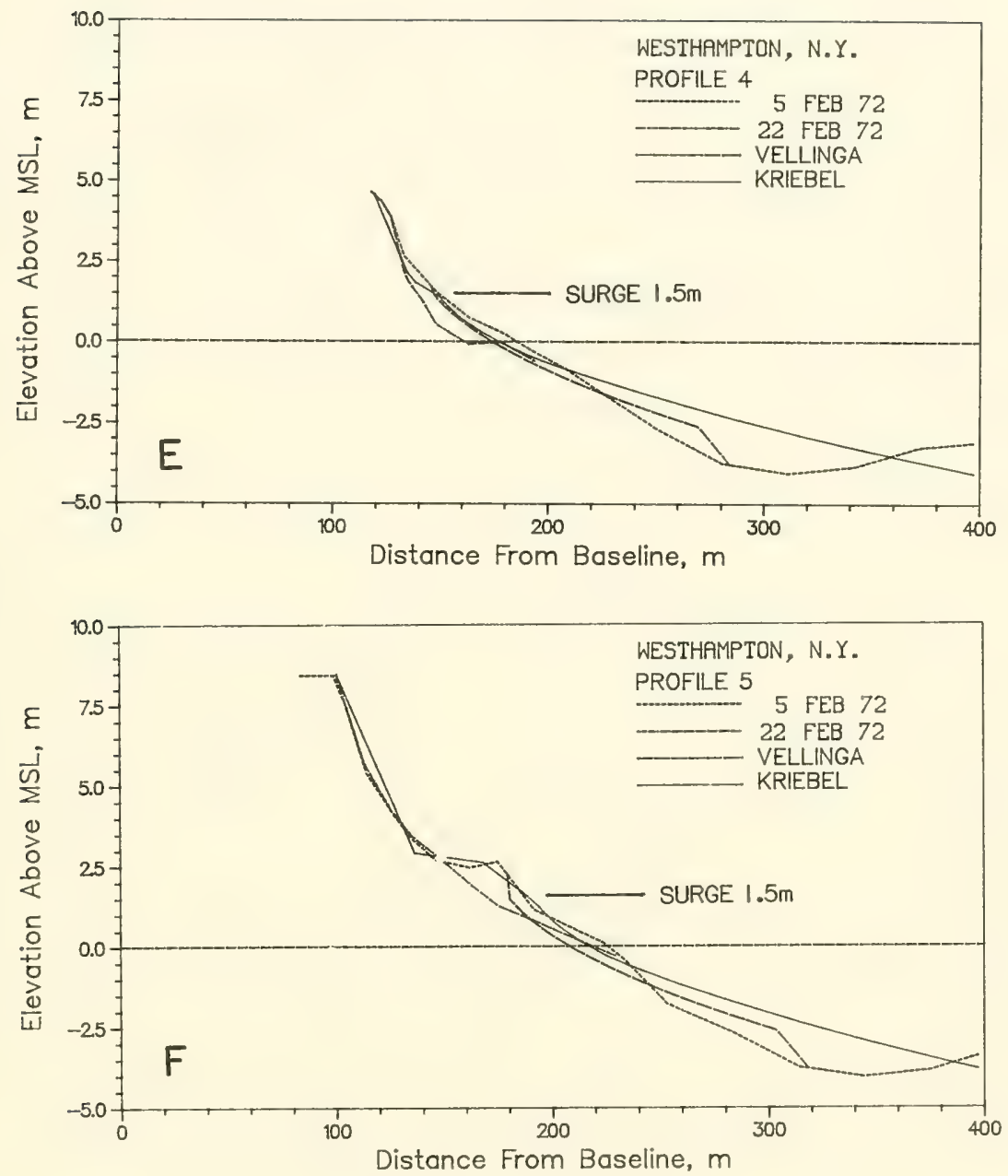

Figure 16. (Sheet 3 of 7) 

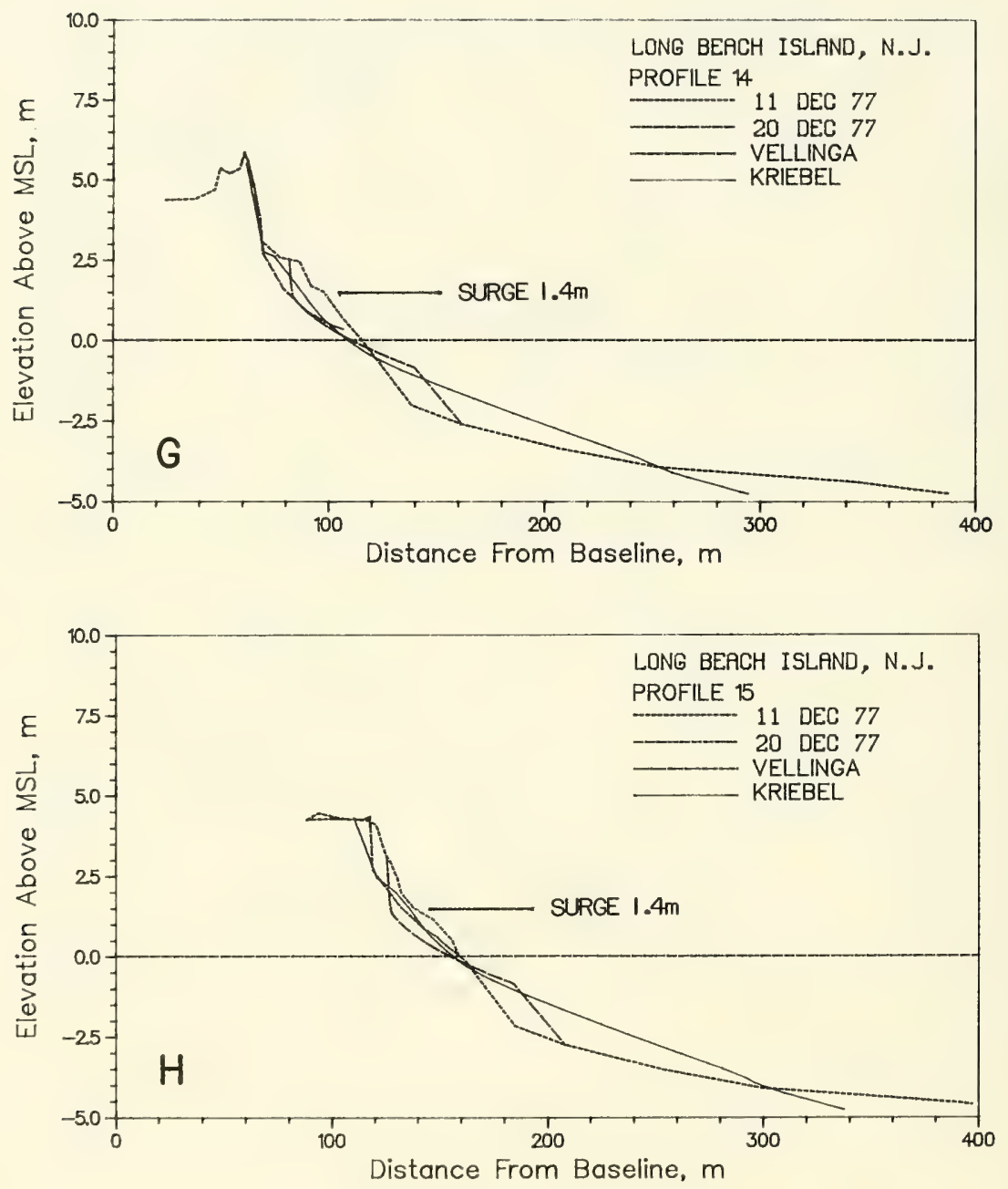

Figure 16. (Sheet 4 of 7) 

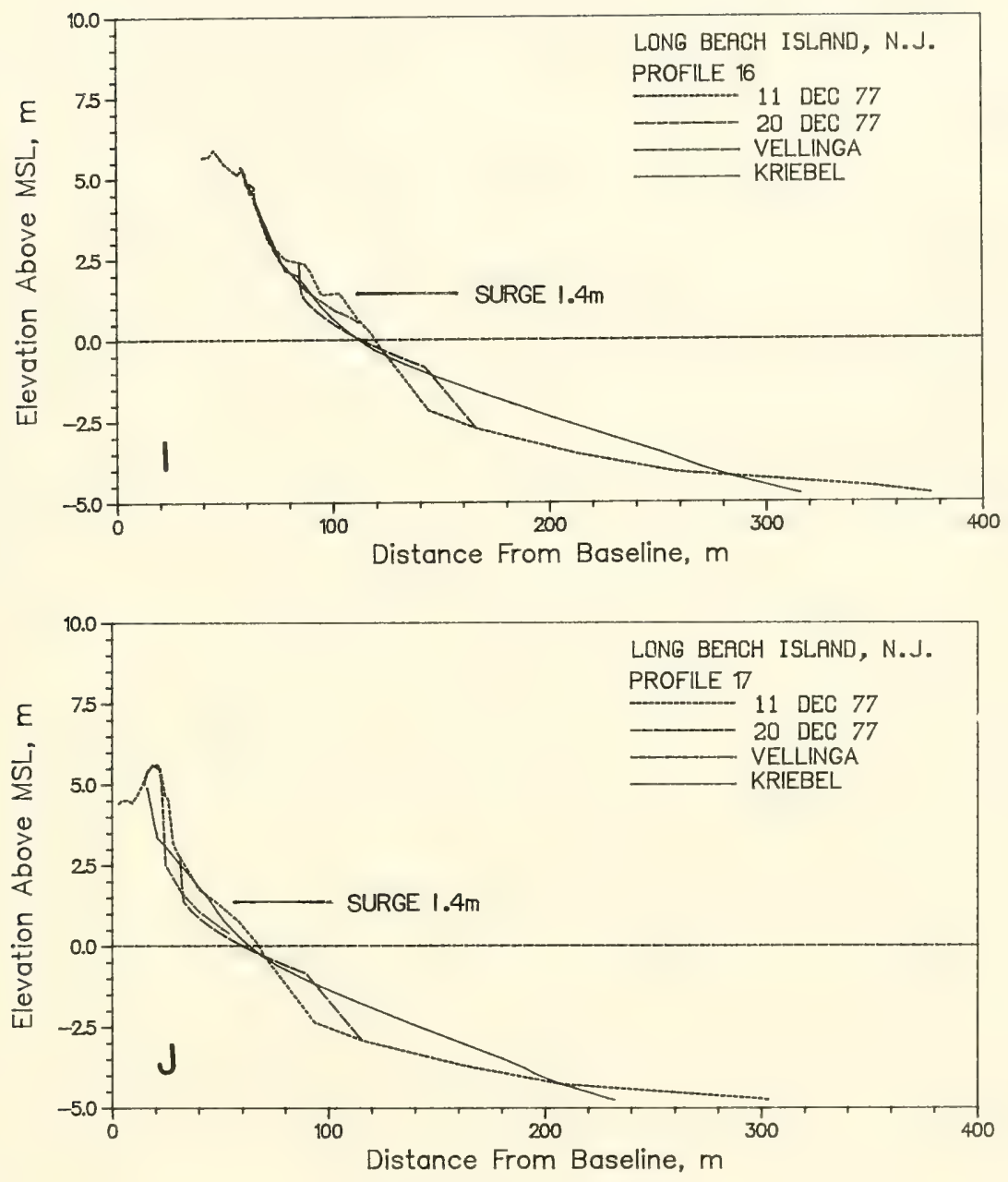

Figure 16. (Sheet 5 of 7) 

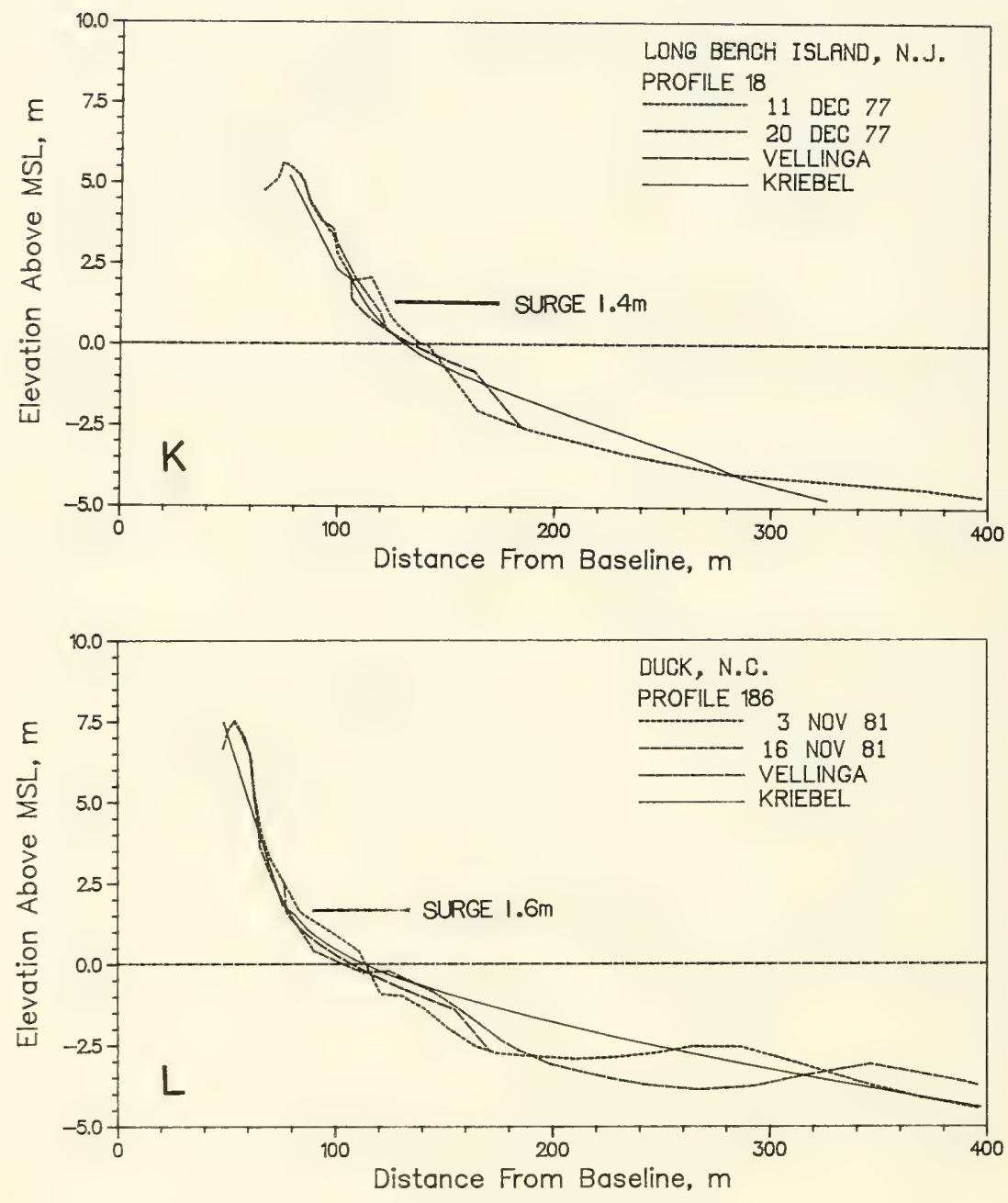

Figure 16. (Sheet 6 of 7) 

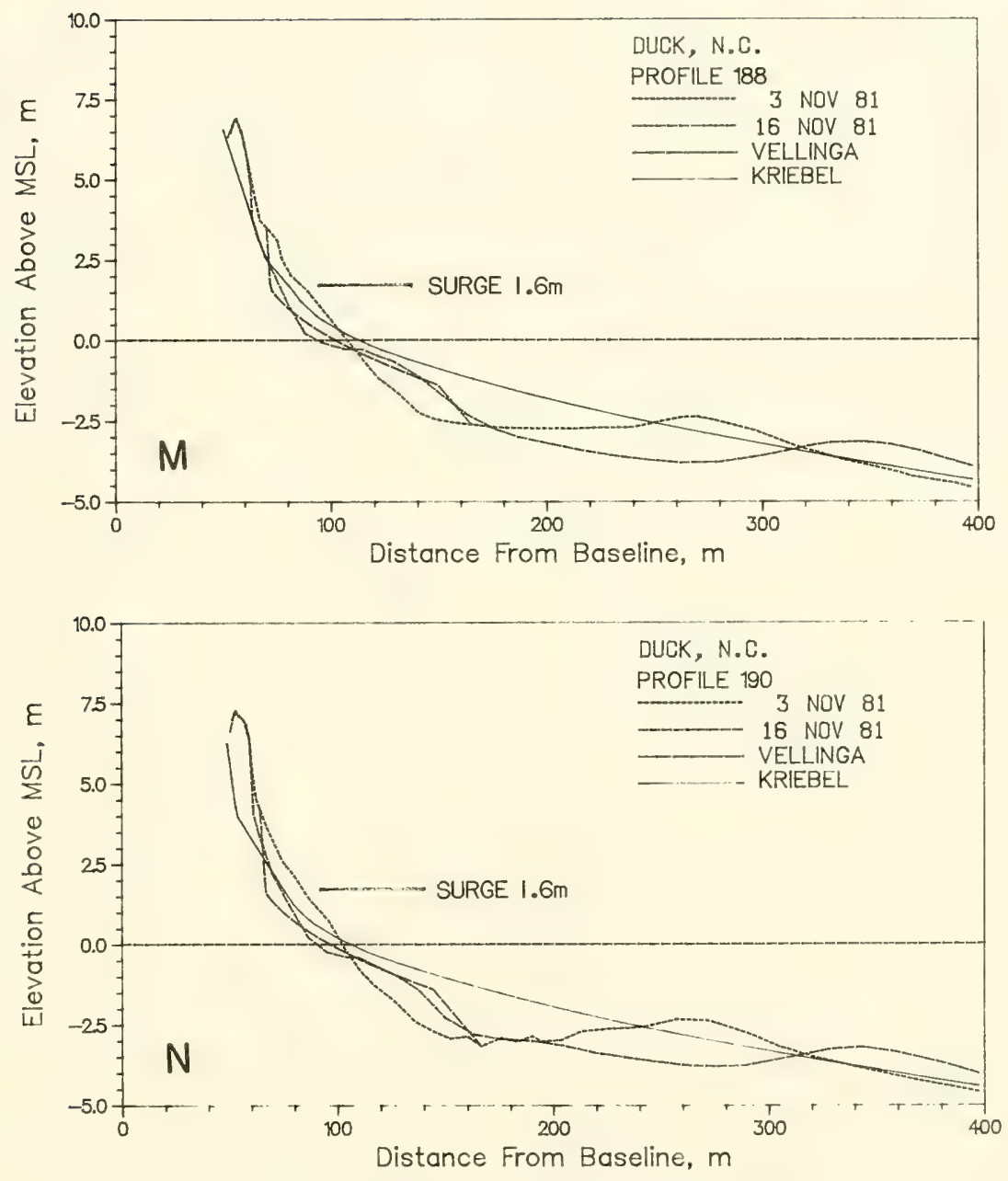

Figure 16. (Sheet 7 of 7) 


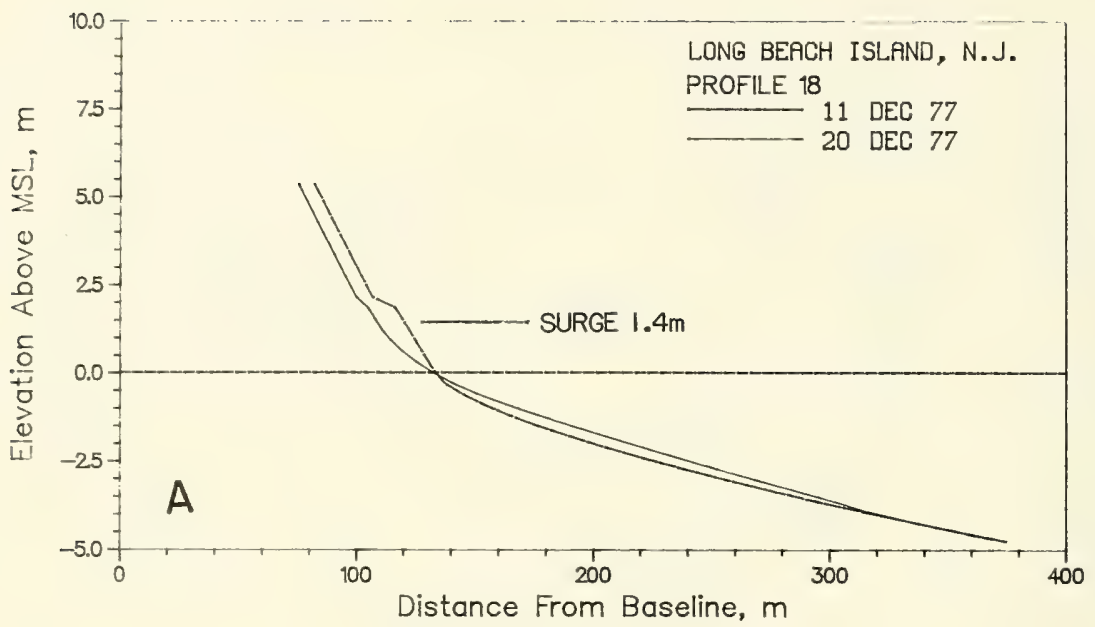

a. Worst comparison

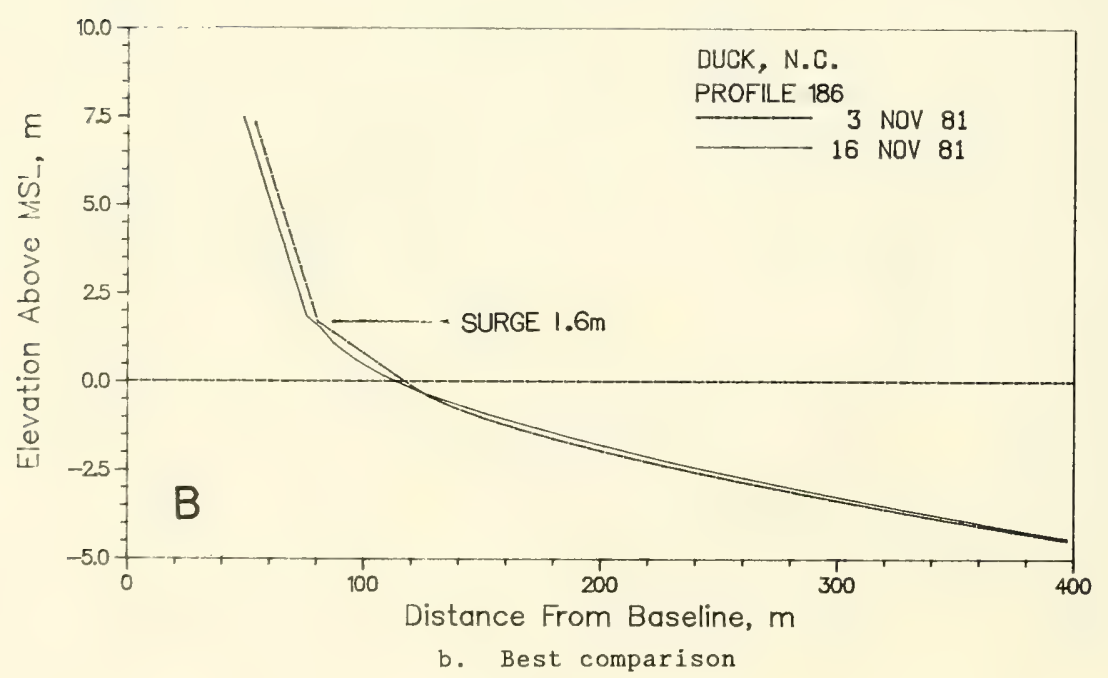

Figure 17. Profile changes predicted by the Kriebel model for the worst and best comparisons given in Table 4 
capable of an adequate prediction of gross storm related erosion. In view of this observation, a necessary comparison of the models must be made which will assess the performance of each with respect to changes in certain of the basic input parameters. Sargent and Birkemeier (1985) presented plots, reproduced in Figures 18 and 19 , showing predicted erosion volumes for a specific profile shape (5-m-high dune of infinite width) as a function of sediment diameter, deepwater significant wave height, and surge height. Similar sensitivity plots, using a schematic representation of the same profile, are presented for the Kriebel model in Figures 20 and 21 . Figure 22 shows the volumes of erosion computed as a function of storm duration. The shape coefficient A is primarily a function of the sediment diameter; therefore, Figures 18 and 21 are approximately equivalent. The limited effect of wave height on the Kriebel results is readily apparent in Figure 20, particularly between wave heights of 6 and $8 \mathrm{~m}$. The coefficient $A$ and the storm duration have a greater impact.

102. It is difficult to compare the two models simply by examining the estimated volumes of erosion which would occur as a result of a given storm

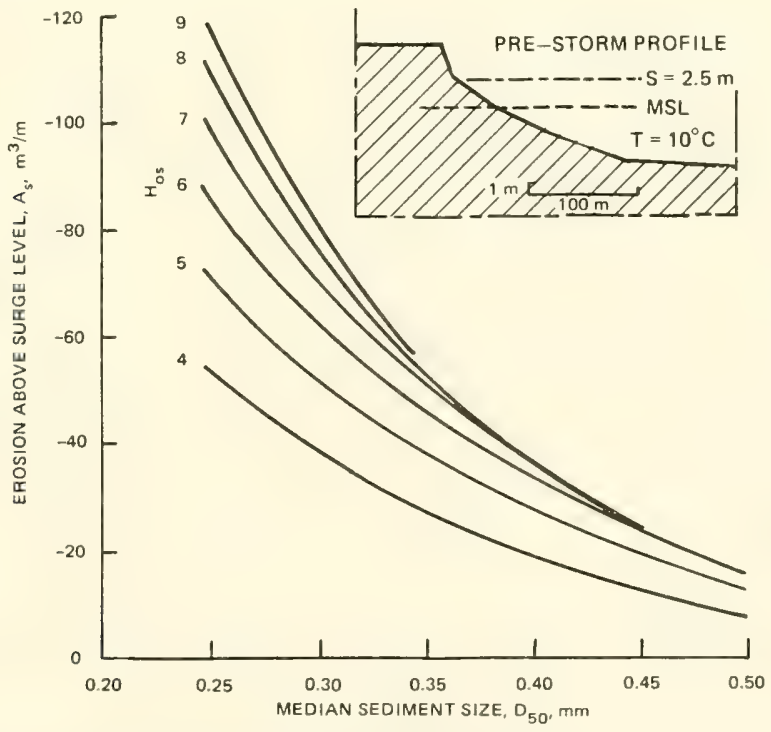

Figure 18. Relationship between erosion above surge level, median sediment size, and deepwater wave heights for the Vellinga model (Sargent and Birkemeier 1985) 


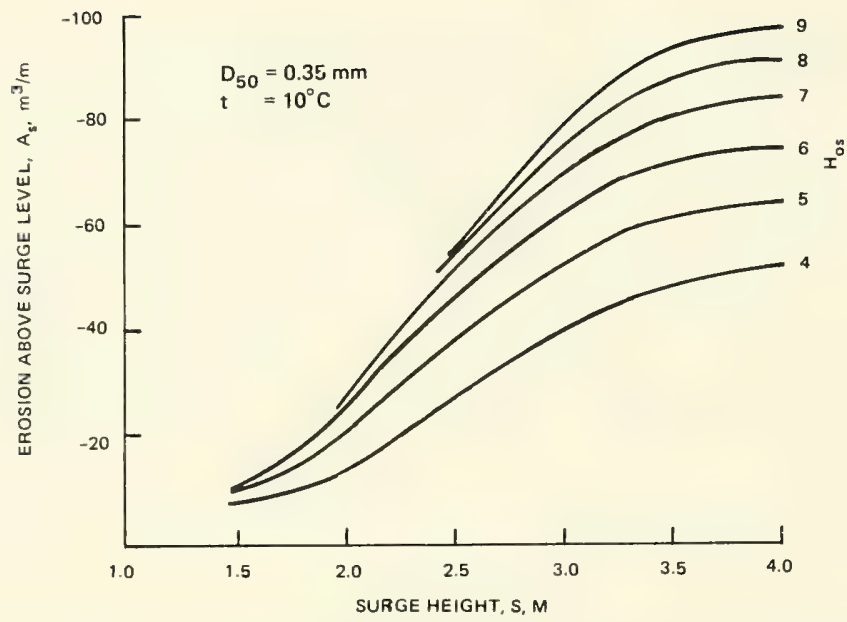

Figure 19. Relationship between erosion above surge level, surge level, and the deepwater wave height for the Vellinga model (Sargent and Birkemeier 1985)

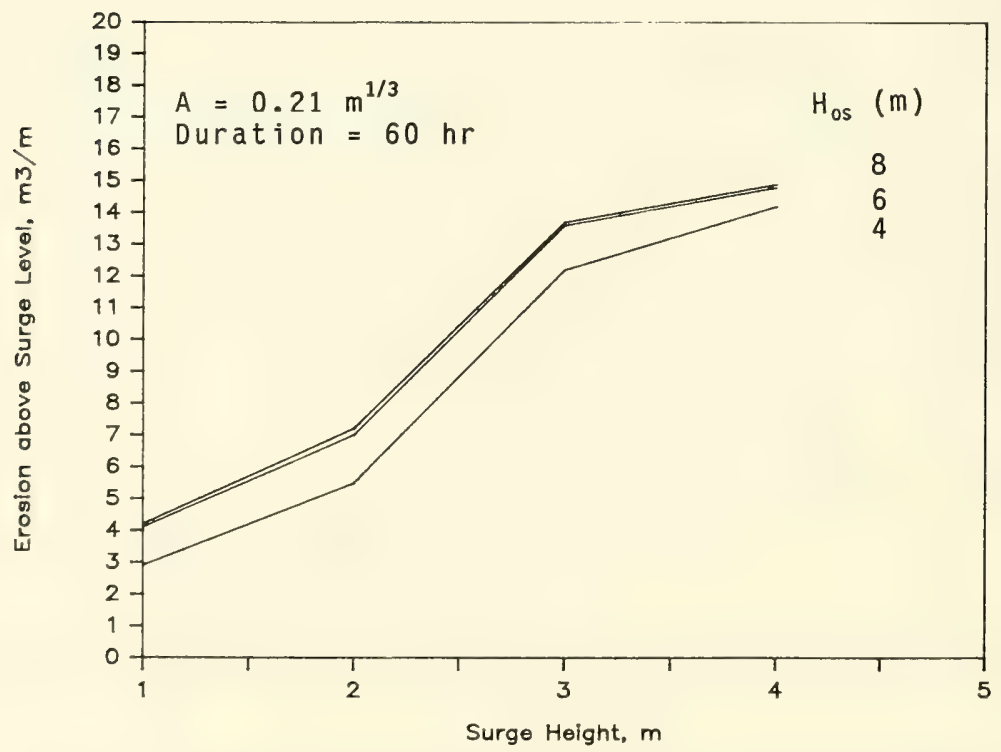

Figure 20. Relationship between total erosion, surge height, and deepwater wave height for the Kriebel model 


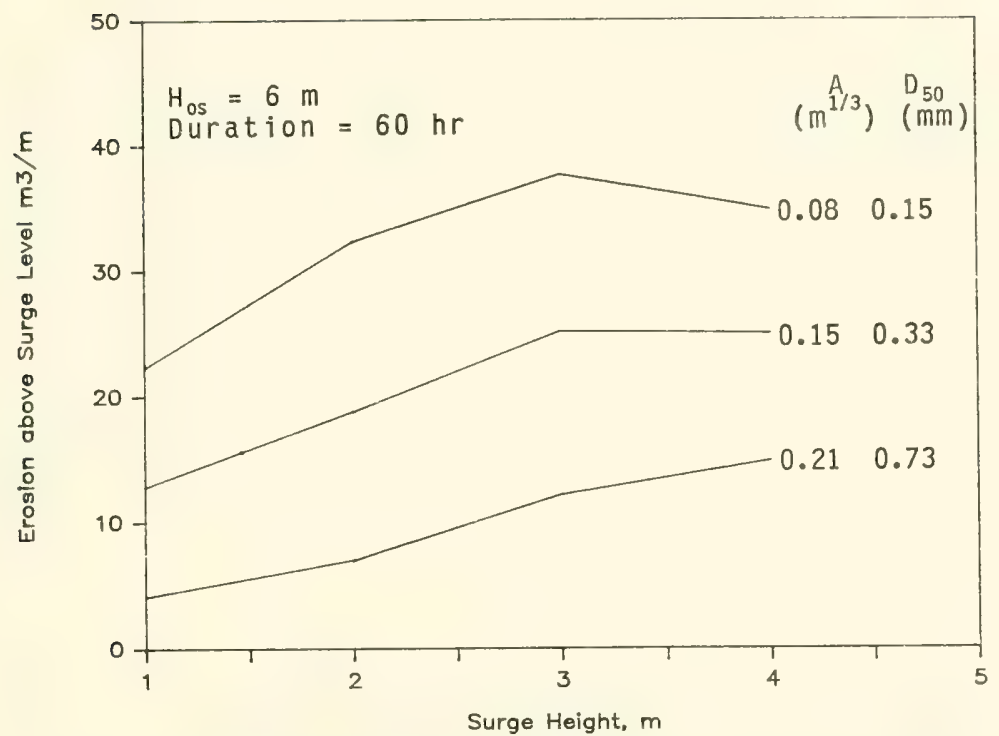

Figure 21. Relationship between total erosion, surge height, and profile shape parameter A for the Kriebel model

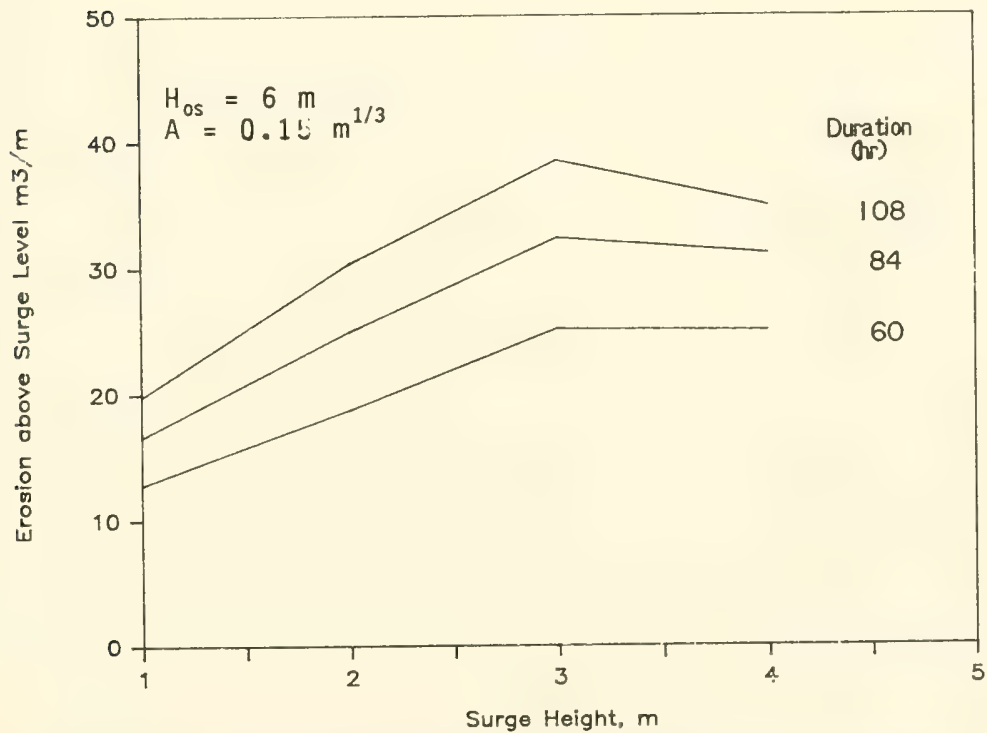

Figure 22. Relationship between total erosion, surge height, and storm duration for the Kriebel model 
event, since entirely different assumptions were made in their development. An obvious example is the difference in surge duration; nevertheless, one type of comparison of the models can still be made. This comparison is accomplished by examining the sensitivity of both models using the percent changes in predicted volume of erosion which occur as a result of similar percentage changes in equivalent input parameters. Table 5 presents several of these comparisons which were computed from the data presented in Figures 18 through 22 demonstrating that both models are stable for the parameter range tested. The Vellinga model is most sensitive to the surge level used and the grain size. The Kriebel model is less sensitive to changes in most parameters.

Table 5

Sensitivity Testing

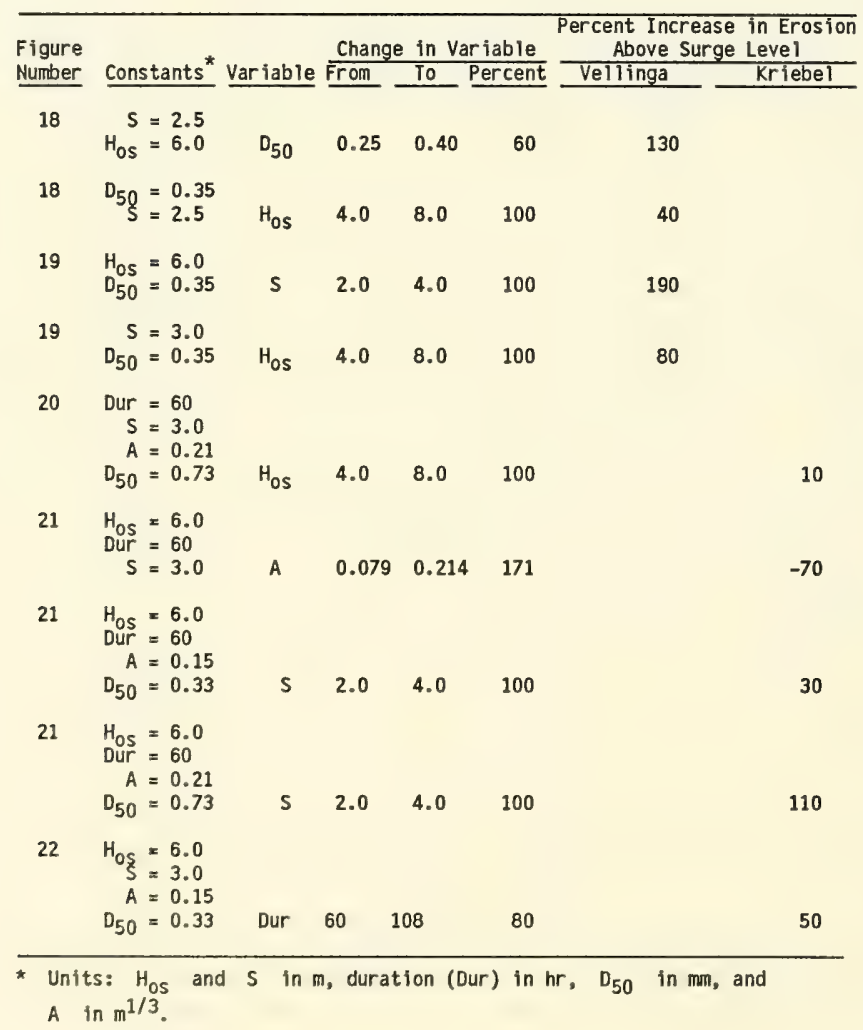




\section{Other Evaluations}

103. Recently, both Kriebel (1986) and Vellinga (1986) presented additional evaluation data for their models. Kriebel, using an improved and recalibrated version of the model tested here, evaluated 20 poststorm Hurricane Eloise profiles from walton County, Florida, which were deemed representative of the 80 to 90 eroded profile lines available. Maximum measured erosion above MSL was approximately $60 \mathrm{~m} 3 / \mathrm{m}$. All 20 cases were within a 40-percent margin of error, with 17 cases lying within 25 percent. Dune recession tended to be underpredicted.

104. In his dissertation, Vellinga (1986) presents comparisons for three different events, including one profile from Hurricane Eloise. The largest storm, the 1953 storm surge, caused an average of $90 \mathrm{~m}^{3} / \mathrm{m}$ of erosion and formed the basis for much of the development of the Vellinga and earlier Dutch models. The Vellinga model estimated an average 10 ss of $97 \mathrm{~m}^{3} / \mathrm{m}$ for this event. The comparison containing the most data (58 cases) documented the 1976 storm surge which produced an average loss of $32 \mathrm{~m}^{3} / \mathrm{m}$. This overall loss is well estimated by the model, though individual profile changes show considerable scatter with differences up to 400 percent. Good agreement was also obtained for the one profile from Hurricane Eloise.

105. Chiu and Dean (1986) evaluated two Florida profiles eroded by hurricanes using a highly simplified version of the Kriebel model (Chiu and Dean 1984) and found that, even with a variability factor of 2.5 , the predicted horizontal recession of the dune face was underestimated.

\section{Conclusions}

106. Based on the comparison in the above section, both the Vellinga and Kriebel models have been shown to produce reasonable estimates of dune erosion. The models are stable with respect to the input parameters if they lie within reasonable physical limits. The Vellinga model requires a detailed knowledge of the initial beach and offshore profile and the storm surge level in order to predict storm erosion volumes and the associated poststorm profiles. It can be seen from the governing equation of the Vellinga model that both the predicted profile shape and offshore termination point are highly dependent on the estimated deepwater significant wave height. 
Moreover, the method is expected to work best with profiles similar in slope to those on the Dutch coast. As pointed out by Sargent and Birkemeier (1985), for much flatter slopes the predicted profile may be too steep to balance the erosion and deposition. Finally, an accurate representation of the offshore profile shape through the storm surf zone is required. The more different the prestorm and predicted poststorm shapes are, the higher the erosion. Offshore survey data, particularly through the surf zone, are difficult and costly to obtain, and the dynamic nature of this zone diminishes the value of a single survey for long-term estimates by FEMA. Use of the Vellinga model is not recommended except possibly to supplement the Kriebel model for conditions suited to its range of applicability. It could be particularly useful in situations where the prestorm offshore profile shape is known and the surge duration is not.

107. The Kriebel model is a more sophisticated and generalized dune erosion predictive technique than the empirically based Vellinga model, because it is based on a predictive transport rate formula and has a time dependency. The Kriebel model requires only a schematized prestorm profile (which can be obtained from measurements or calculated within the framework of the model), storm surge hydrograph, and the deepwater wave height. The capability to use a generalized profile shape is an advantage compatible with FEMA's standardized calculation procedures because the model is relatively insensitive to small changes in the beach profile that continuously occur through time. In conclusion, based primarily on this ability to use a schematic prestorm profile and because it is relatively insensitive to minor variations in surge level, wave height, and duration, the Kriebel model is recommended as being the most suitable for use by FEMA. 


\section{PART VI: A SYSTEMATIC APPROACH TO V-ZONE DETERMINATION}

108. This section describes a methodology for inclusion of the erosion process in V-zone determination which combines use of the Kriebel and Vellinga models with field measurements, interpretation of historic data, and engineering judgments. If correctly implemented, the described procedure should result in rational and consistent $V$-zone widths. Areas for which the procedure is most applicable are also identified.

109. It is worthwhile to note that the recommendations to be made here, though independently determined, are similar to procedures currently implemented by the state of Florida in establishing a Coastal Construction Control Line which is based on the storm surge, waves, and erosion caused by a 100-year storm (Chiu and Dean 1984). The use of a highly simplified version of the Kriebel model is augmented by an extensive program of field data collection which includes beach and nearshore surveys around the state. Data collected as part of this program are used to further verify and improve erosion predictions. A number of major storms have already been documented and are reported by Chiu (1977) and Balsillie (1985c, 1985d).

\section{Use of the Model}

110. We recommend a straightforward application of the Kriebel model, as specified in the appropriate references. Refinements discussed by Kriebel (1986), though not tested here, should be included. The Vellinga model will probably not be as widely applicable in its present form as the Kriebel model but may be useful in some areas. Use of the MSBWT model is not yet recommended because of its lack of independent verification. The easily computed erosion estimates given by Equation 13 may, however, be useful as an independent check on above-MSL erosion estimates. Further evaluation of the MSBWT model is suggested particularly with respect to its simulation of such features as bar formation and overwash.

111. Actual beach survey data are used to define the slopes and berm features. The equilibrium slope equation of the offshore, based preferably on actual surveys or grain size (see Balsillie 1982), is determined. Then the Kriebel model is run using the 100-year surge level (including the tide) and duration. FEMA currently computes both the surge level and hydrograph 
for each synthetic hurricane generated for the determination of the 100-year surge leve1; however, the hydrographs are not saved. Since for northern states the surge and duration associated with a northeaster may be higher and longer, respectively, these quantities must also be determined.

112. Once the model has been used to compute an estimate of the volume loss above the surge level, this estimate is multiplied by the variability factor (e.g., 2.0 from Part $I$, or another representative value). If inadequate dunes exist to survive this loss, the back-dune area is allowed to flood.

113. Because the flooding will be caused by localized dune breaching and overwash (unless the surge level erodes or overtops the dune crest), the depth of flooding is difficult to predict. If the surge is of short duration, the flooding will occur as weir flow, and there will be a drop in water level across the eroded dune. However, once the dune overwashes inland, the maximum surge level should be assumed. Since the overwash process is poorly documented and unquantified, a conservative and recommended approach is to use the maximum flood level if the dune is flooded.

114. Finally, the results should be evaluated (i.e., given a final engineering review) for reasonability relative to historic data and results for adjacent or similar areas.

\section{Historic Data and Long-Term Erosion}

115. Considering our basic lack of understanding of the beach erosion process, the best and most direct estimate of erosion during a possible future storm is made through use of measurements collected during similar storms. This procedure is seldom practical. Either the data are of insufficient quality or, more frequently, the design storm has never occurred or been measured. The large variability discussed in Part I further complicates the situation. However, historic shoreline position data (surveys, air photos, high-water marks, etc.) should always be used as a check of numerical predictions. A good example of the potential use of historic data is in the determination of overwash zones. In many areas, poststorm aerial photographs have documented overwash penetration limits. Since many storms are less severe than a 100-year event, these photographs provide a direct measure of at least minimum overwash penetration distances. Overwash features are 
usually detectable long after they are formed. V-zone limits should ignore the existing dune (use the maximum surge level) in areas of historic overwash unless the shoreline has been significantly altered through the construction of a substantial duneline or high seawall.

116. Although long-term erosion is not of primary concern during a 100-year event, its importance to storm-related losses cannot be discounted. Quite simply, areas prone to long-term erosion will sustain greater damage during the 100-year event and during every lesser event that precedes it. Moreover, the protection offered by a substantial duneline may not survive until the 100-year storm.

117. Long-term erosion rates are usually based on measurements of the shoreline position inferred from aerial photographs (or occasionally based on actual surveys) taken 10 to 40 years apart. Usually, only a few measurements through time are available, so the rates do not reflect rapid seasonal or storm changes. They do provide an indication of how one section of shoreline changes relative to another. Unfortunately, inclusion of a long-term erosion rate requires specification of a time span. Predicted shoreline positions might be computed, for example, based on a 30-year mortgage life or a 70-year structure life. Whereas arguments can be made for both, use of a particular time span may be unrealistic in determining V-zones. Yet, some provision for recognizing high erosion areas must be included.

118. Although this study does not specifically address this problem, it may be possible to indirectly include some measure of long-term erosion by adjusting the value of the variability factor for known high erosion areas. Because the variability factor is based on longshore variability during storms, it is reasonable to assume that it also reflects long-term longshore variations since they result from the integrated effect of many storms. Therefore, use of a variability factor based on the extreme value (instead of the 75 percent) could be used in high erosion areas which could be classified into general erosion categories of low, medium, and high rates based on long-term measurements. Dunes in high erosion zones would have to be more substantial than those in stable or low eroding areas. Further research on this or an alternative method and a thorough evaluation using field data are required. 


\section{Coastal Areas Suitable for Mode1 Application}

119. Three types of coastlines have been classified according to suitability for model application along the $5,600 \mathrm{~km}$ of the Gulf of Mexico and Atlantic Ocean coasts. These classifications are 1 isted in Table 6.

Table 6

Classification of Coast for Application of Dune Erosion Model

\begin{tabular}{|c|c|c|c|}
\hline Type & Description & Examples & $\begin{array}{l}\text { Percent Gulf and } \\
\text { At lantic Coast* }\end{array}$ \\
\hline $\begin{array}{l}\text { I. Mostly } \\
\text { suitable }\end{array}$ & $\begin{array}{l}\text { Sand beaches with- } \\
\text { out structures or } \\
\text { high erosion; with } \\
\text { or without dune- } \\
\text { line. }\end{array}$ & $\begin{array}{l}\text { South Texas; Florida } \\
\text { panhandle;Outer Banks, } \\
\text { N.C. }\end{array}$ & 54 \\
\hline $\begin{array}{l}\text { II. Marginally } \\
\text { suftable }\end{array}$ & $\begin{array}{l}\text { Limited extent of } \\
\text { sand beaches, } \\
\text { high erosion } \\
\text { and/or structured. }\end{array}$ & $\begin{array}{l}\text { Portions of New Jersey } \\
\text { coast, southern Maine }\end{array}$ & 24 \\
\hline $\begin{array}{l}\text { III. Not } \\
\text { required }\end{array}$ & $\begin{array}{l}\text { Typically rocky, } \\
\text { cliffed, or other } \\
\text { nonsand beaches. }\end{array}$ & $\begin{array}{l}\text { Eastern Long Island, } \\
\text { N.Y.; Ten Thousand } \\
\text { Islands, Fla. }\end{array}$ & 22 \\
\hline
\end{tabular}

* Percentages are approximate.

Approximately 22 percent of this coast is nonsandy (mud or rock) where the model is not required and existing FEMA procedures should be used. These regions are classified as Type III. Of the remaining 78 percent, approximately 69 percent consists of sandy beaches where use of the model is classified as Type I, "mostly suitable." The remaining coast is classified as Type II, "marginally suitable," either because of high annual erosion rates (greater than $3 \mathrm{~m} /$ year) or because of a high concentration of coastal structures. Figure 23 and Table 7 identify the areas which are classified as either marginally unsuitable or not required.

120. Within the Type I coast, the limitations of the model restrict its use. Obviously, the model should only be applied, and is only required, in areas where the dune crest is higher than the surge level. The Kriebel model will function on low dunes but only up to the point in the surge hydrograph when the dune is overtopped, a feature which may be useful. Low areas without dunes should be treated as flooded profiles.

121. Additional care must be exercised in using the models in a Type II zone. If the basic assumptions of the model are satisfied, the results should be meaningful. Potential problem areas are those where strong 


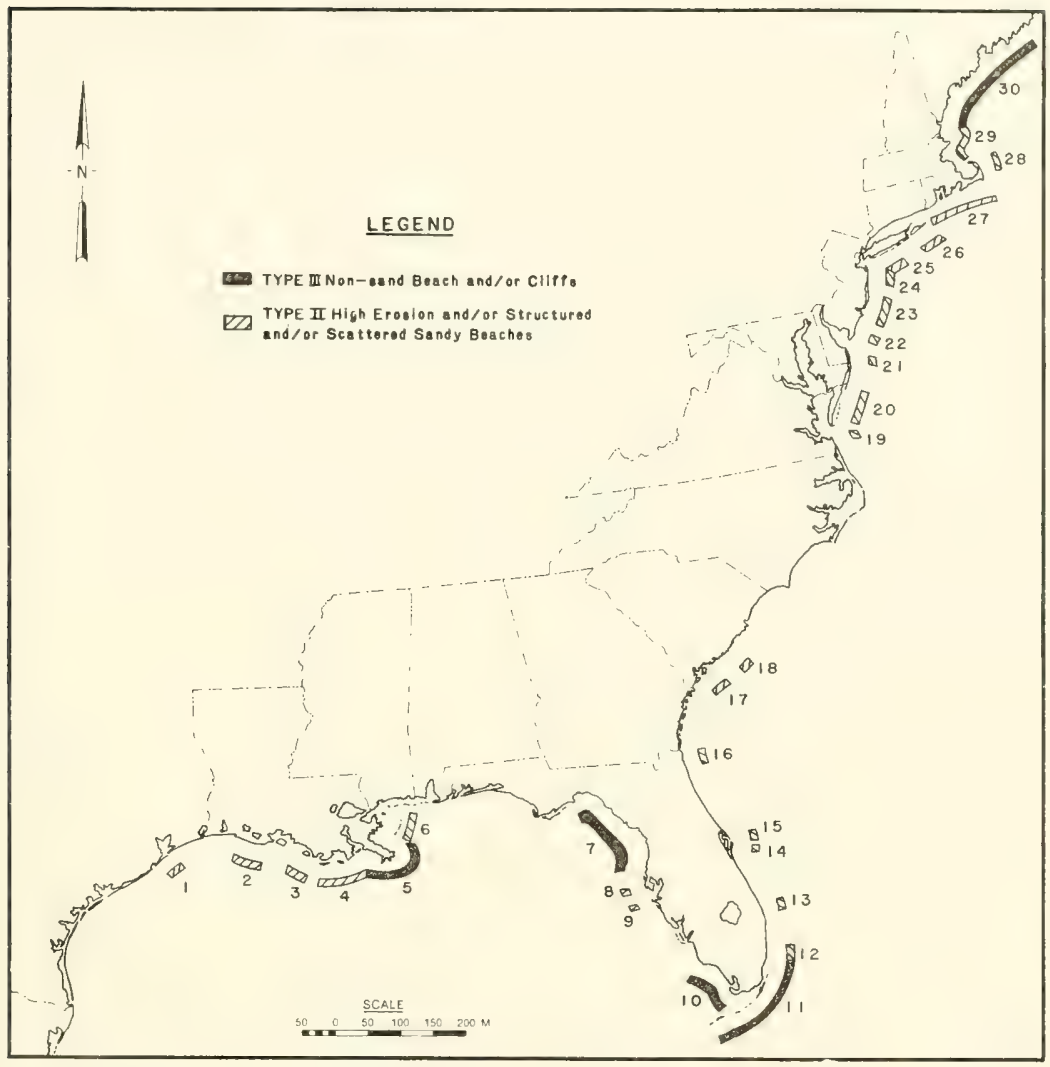

Figure 23. Applicability of the Vellinga and Kriebel dune erosion models along the east and gulf coasts (areas not marked are Type I, mostly suitable)

longshore gradients in sediment transport are known to exist, such as near tidal inlets and coastal headlands.

\section{Role of Engineering Judgment}

122. Although it is desirable to have a tool which would produce accurate and consistent predictions of dune erosion and resulting $V$-zone widths, no such model exists nor is expected to exist in the foreseeable 
Table 7

Location and Description of Mostly Unsuitable and Marginally

\section{Suitable Coastal Areas}

\begin{tabular}{|c|c|c|c|}
\hline Area & Type & Location & Description \\
\hline 1 & II & Galveston Island, Tex. & Structured \\
\hline 2 & II & Cameron and Vermilion Parishes, La. & Erosional \\
\hline 3 & II & Terrebonne Parish, La. & Erosional \\
\hline 4 & II & Terrebonne-Jefferson Parishes, La. & Erosional \\
\hline 5 & III & Mississippi river delta front, La. & Marsh/mud coast \\
\hline 6 & II & Chandeleur Is lands, La. & Erosional \\
\hline 7 & III & Lighthouse Point to Anclote Key, Fla. & Marsh coastiline \\
\hline 8 & II & Pinellas County beaches, Fla. & Structured \\
\hline 9 & II & Anna Maria Island, Fla. & Highly erosional \\
\hline 10 & III & Cape Romano to Flamingo, Fla. & Mangrove coast \\
\hline 11 & III & Florida Keys to Coral Gables, Fla. & Limestone is lands \\
\hline 12 & II & Miami, Fla. & Structured \\
\hline 13 & II & North Palm Beach to Lake Worth, Fla. & Structured \\
\hline 14 & II & Cocoa Beach to Indian Harbor Beach, Fla. & Structured \\
\hline 15 & II & Cape Canaveral, Fla. & Erosiona 1 \\
\hline 16 & II & Duval County, Fla. & Erosional \\
\hline 17 & II & Hunting and Pritchards Is lands, S.C. & Erosional \\
\hline 18 & II & Capers and Morr is Islands, S.C. & Erosiona 1 \\
\hline 19 & II & Virginia Beach, Va. & Structured \\
\hline 20 & II & Virginia Barrier Islands, Va. & Erosional \\
\hline 21 & I I & Ocean City, Md., to Bethany Beach, De. & Structured \\
\hline 22 & II & Cape May to Sea Isle City, N.J. & Structured \\
\hline 23 & II & Ocean City to Seaside Heights, N.J. & Structured \\
\hline 24 & II & Point Pleasant to Sandy Hook, N.J. & Structured \\
\hline 25 & II & Rockaway Beach to Oak Beach, N.Y. & Structured \\
\hline 26 & II & Southampton to Montauk Point, N.Y. & Cliffed coast \\
\hline 27 & II & Rhode Is land, southern Mass. & Rocky or cliffed \\
\hline 28 & II & Eastham to Race Pt., Cape Cod, Mass. & Sand/till cliff \\
\hline 29 & II & Plymouth, Mass., to New Castle, N.H. & Rocky or cliffed \\
\hline 30 & III & North of N.H./Mass state line & Rocky coast \\
\hline
\end{tabular}

future. Our inability to understand and correctly model the underlying processes, combined with the natural variation and the uncertainty in predicting future storms, precludes the development of a model based on first principles. Consequently, we must use simpler models for guidance and combine that guidance with other sources of data, as described above, and experienced engineering judgment.

123. Similar guidance is a cornerstone of other FEMA procedures. Use of historical data and engineering judgment is an often repeated recommendation in the "Guidelines for Identifying Coastal High Hazard Zones" (US Army Engineer District, Galveston 1975). With reference to sand dunes, this report states,

In many instances, substantial sand dunes with heights of 15 ft above sea level and base widths of several hundred feet have been swept away by storm surge and accompanying waves. Unless historical data indicate that sand dunes in the area have repeatedly withstood wave attack during storms, they should not be considered as effective surge and wave barriers. 
Although presently available models can objectively help to reduce the uncertainty, this advice remains true today. When the engineer is faced with a marginal duneline, it should not be considered an effective wave barrier. 


\section{PART VII: SUMMARY AND CONCLUSIONS}

124. This report has examined the merits of both theoretically based and parameterized models for possible use in estimating the impact of dune erosion in mapping high hazard V-zones. Among these, only the empirically based models were shown to produce reasonable results with a minimum of effort and required input data. Of the models evaluated in this feasibility study, the Kriebel model was judged superior to the Vellinga model, not because it produced more accurate results but because it (a) is applicable to a wider range of beach configurations; (b) is less demanding in terms of the accuracy requirements of the input data; and (c) accounts for storms of varying duration. This last capability is particularly important because Atlantic coast beaches are affected by both short duration hurricanes and long duration northeasters.

125. Currently, the Kriebel model does not fulfill all the requirements of an ideal erosion model. Its limitations include an inability to model offshore bars, a dependence on an overly simplistic profile shape, and an insensitivity to varying wave conditions. Nevertheless, if properly implemented, the Kriebel model is expected to produce reasonably accurate dune erosion estimates, and it is believed that the capability of the model may be improved in the future.

126. The foregoing conclusion is based on examination of available models, including the comparison given in Part IV. This comparison augmented the limited verification of both the Kriebel and Vellinga models which had been done to date. The Kriebel model was originally developed as a Master's thesis and was evaluated with a single Florida profile surveyed after the 1975 Hurricane Eloise. Kriebel (1986) provided additional verification using 20 Florida profiles from Hurricane Eloise. Considerable data now exist which would permit a more extensive evaluation. For example, the State of Florida has hundreds of profiles surveyed after storms (Balsillie 1985c, d; Chiu 1977).

127. Time constraints of this study permitted only a limited amount of testing to be conducted. Consequently, if the recommended Kriebel model is adopted, the experience that FEMA gains through use of the model on a wider variety of coastal areas should be applied to improving the model and its implementation. 
128. The reviewed MSBWT model has a number of potentially attractive features, including use of a probabilistic approach to erosion quantities, provision for overwash, and a duration dependency based on the rise time of the peak surge. Though it is too complex and undeveloped for the present needs of FEMA, this model may be useful in the future.

129. Because none of the models can adequately account for the normal alongshore variation in profile changes, use of the variability factor (see Part II) as a multiplier of the predicted erosion quantities will help ensure that reasonable erosion estimates are obtained. 


\section{REFERENCES}

Andrews, P. B. 1970. "Facies and Genesis of a Hurricane Washover Fan, St. Joseph Island, Central Texas Coast," Report No. 67, Texas Bureau of Economic Geology, Austin, Tex.

Armon, J. W. 1979. "Landward Sediment Transfers in a Transgressive Barrier Island System, Canada," in Leatherman, S. P., ed., Barrier Islands from the Gulf of St. Lawrence to the Gulf of Mexico, Academic Press, New York, N.Y., pp 291-319.

Aubrey, D. G., and Trowbridge, J. H. 1985. "Kinematic and Dynamic Estimates from Electromagnetic Current Meter Data," Journal of Geophysical Research, Vol 90, No. C5, pp 9137-9146.

Bagnold, R. A. 1963. "Mechanics of Marine Sedimentation," in E.M. Hill, ed., The Sea: Ideas and Observations, Vol 3, Interscience Publishers, New York, N.Y., pp 507-526.

- 1966. "An Approach to the Sediment Transport Problem from General Physics," United States Geological Survey Professional Paper, No. $422-I$.

Bailard, J. A. 1981. "An Energetics Total Load Sediment Transport Model for a Plane Sloping Beach," Journal of Geophysical Research, Vol 86, No. C 11 , pp $10938-10954$.

- 1982. "A Model for On-Offshore Sediment Transport in the Surfzone," Technical Report N-1649, Naval Civil Engineering Laboratory, Port Hueneme, Calif.

1983. "Modeling On-Offshore Sediment Transport in the Surfzone," Proceedings of the 19th Coastal Engineering Conference, American Society of Civil Engineers, pp 1419-1438.

- 1985. "Simple Models for Surfzone Sediment Transport," Technical Note $\mathrm{N}-1740$, Naval Civil Engineering Laboratory, Port Hueneme, Calif.

Balsillie, J. H. 1982. "Offshore Profile Descriptions Using the Power Curve Fit, Part I: Explanation and Discussion," Beaches and Shores Technical and Design Memorandum No. 82-1-I, Division of Beaches and Shores, Florida Department of Natural Resources, Tallahassee, Fla.

1984a. "Wave Length and Wave Celerity during Shore Breaking," Beaches and Shores Technical and Design Memorandum No. 84-1, Division of Beaches and Shores, Florida Department of Natural Resources, Ta11ahassee, Ela. 
Balsillie, J. H. 1984b. "Attenuation of Wave Characteristics Following ShoreBreaking on Longshore Sand Bars," Beaches and Shores Technical and Design Memorandum No. 84-3, Division of Beaches and Shores, Florida Department of Natural Resources, Tallahassee, Fla.

1984c. "A Multiple Shore-Breaking Wave Transformation Computer Mode1, "Beaches and Shores Technical and Design Memorandum No. 84-4, Division of Beaches and Shores, Florida Department of Natural Resources, Tallahassee, F1a.

- 1985a. "Calibration Aspects for Beach and Coast Erosion due to Storm and Hurricane Impact Incorporating Event Longevity," Beaches and Shores Technical and Design Memorandum No. 85-1, Division of Beaches and Shores, Florida Department of Natural Resources, Tallahassee, Fla.

- 1985b. "Verification of the MSBWT Numerical Model: Coastal Erosion and Four Climatological Events and Littoral Wave Activity from Three Storm-Damaged Piers," Beaches and Shores Technical and Design Memorandum No. 85-2, Division of Beaches and Shores, Florida Department of Natural Resources, Tallahassee, Fla.

- 1985c. "Post-Storm Report: The Florida East Coast Thanksgiving Holiday Storm of 21-24 November 1984," Beaches and Shores Post-Storm Report No. 85-1, Division of Beaches and Shores, Florida Department of Natural Resources, Tallahassee, Fla.

- 1985d. "Post-Storm Report: Hurricane Elena of 29 August to 2 September 1985," Beaches and Shores Post-Storm Report No. 85-2, Division of Beaches and Shores, Florida Department of Natural Resources, Tallahassee, Fla.

- 1986. "Beach and Coast Erosion due to Extreme Event Impact," Shore and Beach, Vol 54, No. 4, pp 22-37.

- In preparation. "Littoral and Coastal Process Elements of a Storm Erosion and Wave Transformation Numerical Computer Model," Division of Beaches and Shores, Florida Department of Natural Resources, Tallahassee, Fla.

Bartberger, C. E. 1976. "Sediment Sources and Sedimentation Rates, Chincoteague Bay, Maryland and Virginia," Journal of Sedimentary Petrology, Vol 46, No.2, pp 326-336.

Bates, R. L., and Jackson, J. A., ed. 1980. Glossary of Geology, American Geological Institute, Falls Church, Va.

Birkemeier, W. A. 1979. "The Effects of the 19 December 1977 Coastal Storm on Beaches in North Carolina and New Jersey," Shore and Beach, Vol 74, No. 2, pp 7-15.

1985a. "Time Scales of Nearshore Profile Change," Proceedings of the 19th Coastal Engineering Conference, American Society of Civil Engineers, pp 1507-1521. 
Birkemeier, W. A. 1985b. "Field Data on Seaward Limit of Profile Change," Journal of Waterway, Port, Coastal and Ocean Engineering, Vol 111, No. 3, pp 598-602.

Birkemeier, W. A., Savage, R. J., and Leffler, M. W. In preparation. "A Collection of Storm Erosion Field Data," Miscellaneous Paper, US Army Engineer Waterways Experiment Station, Vicksburg, Miss.

Boc, S. J., and Langfelder, J. 1977. "An Analysis of Beach Overwash Along North Carolina's Coast," Center for Marine and Coastal Studies, North Carolina State University, Raleigh, N.C.

Bowen, A. J. 1980. "Simple Models of Nearshore Sedimentation; Beach Profiles and Longshore Bars," in McCann, S. B. ed., The Coastline of Canada, Geological Survey of Canada, Paper 80-10, pp 1-11.

Bowen, A. J., and Inman, D. L. 1971. "Edge Waves and Crescentic Bars," Journal of Geophysical Research, Vol 76 (36), pp 8662-8671.

Bruun, P. 1954. "Coast Erosion and the Development of Beach Profiles," TM-44, US Army Engineer Waterways Experiment Station, Coastal Engineering Research Center, Vicksburg, Miss.

- 1962. "Sea-Level Rise as a Cause of Shore Erosion," Journal of Waterways and Harbor Division, American Society of Civil Engineers, Vol 88, pp $117-130$.

1984. "Beach and Dune Erosion During Storm Surges by P. Vellinga -Discussion," Coastal Engineering, Vol 8, pp 171-188.

Chesnutt, C. B. 1978. "Analysis Results of 10 Movable-Bed Experiments: Laboratory Effects in Beach Studies, Vo1. VIII," CERC MR 77-7, US Army Engineer Waterways Experiment Station, Coastal Engineering Research Center, Vicksburg, Miss.

Chiu, T. Y. 1977. "Beach and Dune Response to Hurricane Eloise of September, 1975," Proceedings of Coastal Sediments 177, American Society of Civil Engineers, pp 116-134.

Chiu, T. Y., and Dean, R. G. 1984. "Methodology on Coastal Construction Control Line Establishment," Beaches and Shores Technical Design Memorandum No. 84-6, Division of Beaches and Shores, Florida Department of Natural Resources, Tallahassee, Fla.

- 1986. "Additional Comparison between Computed and Measured Erosion by Hurricanes," Beaches and Shores Technical Design Memorandum No. 86-1, Division of Beaches and Shores, Florida Department of Natural Resources, Tallahassee, Fla.

Dally, W. R. 1980. "A Numerical Model for Beach Profile Evolution," unpublished M.S. Thesis, Department of Civil Engineering, University of Delaware, Newark, Del. 
Dally, W. R., and Dean, R. G. 1984. "Suspended Sediment Transport and Beach Profile Evolution," Journal of Waterway, Port, Coastal and Ocean Engineering, Vol 110, No. 1, pp 15-33.

Dean, R. G. 1973. "Heuristic Models of Sand Transport in the Surf Zone," Conference on Engineering Dynamics in the Surf Zone, Australia.

- 1976. "Beach Erosion: Causes, Processes, and Remedial

Measures," CRC Reviews in Environmental Control, Vol 6, No. 3, pp 259-296.

- 1977. "Equilibrium Beach Profiles: U.S. Atlantic and Gulf

Coasts," Ocean Engineering Report No. 12, Department of Civil Engineering, University of Delaware, Newark, Del.

Dupre, W. R. 1985. "Geologic Effects of Hurricane Alicia (August 18, 1983) on the Upper Texas Coast," Transactions, Gulf Coast Associations of Geological Societies, Vo1 35, pp 353-360.

Edelman, T. 1968. "Dune Erosion During Storm Conditions," Proceedings of the 11th Coastal Engineering Conference, American Society of Civil Engineers, pp 719-722.

- 1972. "Dune Erosion During Storm Conditions," Proceedings of the 13th Coastal Engineering Conference, American Society of Civil Engineers, pp 1305-1312.

Fisher, J. J. 1967. "Development Patterns of Relict Beach Ridges, Outer Banks Barrier Chain," unpublished Ph.D. Thesis, University of North Carolina, Chape 1 Hill, N.C.

Fisher, J. J., and Simpson, E. J. 1979. "Washover and Tidal Sedimentation Rates as Environmental Factors in Development of a Transgressive Barrier Shoreline," in Leatherman, S. P. ed. , Barrier Islands from the Gulf of St. Lawrence to the Gulf of Mexico, Academic Press, New York, N.Y., pp 127-148.

Fisher, J. S., Leatherman, S. P., and Perry, F. C. 1974. "Overwash Processes on Assateague Island, Maryland," Proceedings of the 14th Coastal Engineering Conference, American Society of Engineers, pp. 1194-1212.

Fisk, H. N. 1959. "Padre Island and the Laguna Madre Flats, Coastal South Texas," in Russe11, R. J. ed., 2nd Coastal Geography Conference, Louisiana State University, Baton Rouge, La., pp 103-125.

Hallermeier, R. J. 1979. "Uses of a Calculated Limit Depth to Beach Erosion," Proceedings of the 16th Coastal Engineering Conference, American Society of Civil Engineers, pp 1493-1512.

- 1984. "Wave Cuts in Sand Slopes Applied to Coastal Models," Journal of Waterway, Port, Coastal and Ocean Engineering, Vol 110, No. 1, pp $34-49$. 
Hattori, M. 1983. "Field Study on Onshore-Offshore Sediment Transport," Proceedings of the 18th Coastal Engineering Conference, American Society of Civil Engineers, pp 923-940.

Hattori, M., and Kawamata, R. 1981. "Onshore-Offshore Transport and Beach Profile Change," Proceedings of the 18th Coastal Engineering Conference, American Society of Civil Engineers, pp 1175-1194.

Hayes, M. O. 1967. "Hurricanes as Geological Agents: Case Studies of Hurricanes Carla, 1961 and Cindy, 1963," Report of Investigation No. 61, Texas Bureau of Economic Geology, Austin, Tex.

Hil1, J. R., and Herchenroder, B. E. 1985. "Computational Model for Computing Dune Erosion," Proceedings of the Conference on Hydraulics and Hydrology in the Small Computer Age, American Society of Civil Engineers, pp 128-133.

Hite, M. P. 1924. "Some Observations of Storm Effects on Ocean Inlets," American Journal of Science, Vol 7, pp 319-326.

Holman, R. A., and Bowen, A. J. 1982. "Bars, Bumps and Holes: Models for the Generation of Complex Beach Topography," Journal of Geophysical Research, Vol 87, No. C1, pp 457-468.

Howard, A. D. 1939. "Hurricane Modification of the Offshore Bar of Long Island," Geography Review, Vo1 29, pp 400-415.

Hughes, S. A. 1978. "The Variation in Beach Profiles When Approximated by a Theoretical Curve," unpublished M.S. Thesis, Coastal and Oceanographic

Engineering Department, University of Florida, Gainesville, Fla.

Hughes, S. A., and Chiu, T. Y. 1981. "Beach and Dune Erosion During Severe Storms," Coastal and Oceanographic Engineering Department, UFL/COEL-TR/043, University of Florida, Gainesville, Fla.

Inman, D. L., and Bagnold, R. A. 1963. "Littoral Processes," in E. M. Hi11, ed., The Sea: Ideas and Observations, Vol 3, Interscience Publishers, New York, N.Y., pp 529-533.

Inman, D. L., and Filloux, J. 1960. "Beach Cycles Related to Tide and Local Wind Regime," Journal of Geology, Vol 68, pp 225-231.

Iwagaki, Y., and Noda, H. 1963. "Laboratory Study of Scale Effects in Two Dimensional Beach Processes," Proceedings of the 8 th Coastal Engineering Conference, American Society of Civil Engineers, pp 194-210.

Jensen, R. E. 1983. "Atlantic Coast Hindcast, Shallow-Water Wave Information," WIS Report 9, US Army Engineer Waterways Experiment Station, Vicksburg, Miss.

Johnson, J. W. 1952. "Sand Transport by Littoral Currents," Proceedings of the 5th Hydraulics Conference, State University of Iowa, Studies of Engineering Bulletin, No. 34, pp. 84-109. 
Kajima, R. et a1. 1983. "Experiments on Beach Profile Change with a Large Wave Flume," Proceedings of the 18th Coastal Engineering Conference, American Society of Civil Engineers, pp 1385-1403.

Knowles, S. C., and Davis, R. A., Jr. 1983. "Hurricane Influence on Holocene Sediment Accumulation in Sarasota Bay, Florida," (abstract), AAPG Bulletin, Vo1 67 , No. 3, p 496.

Komar, P. D. 1983. "Beach Processes and Erosion - An Introduction," in Komar, P. D., ed., Handbook of Coastal Processes and Erosion, CRC Press, Boca Raton, Fla. pp 1-20.

Kraft, J. C. 1971. "Sedimentary Facies Patterns and Geologic History of a Holocene Marine Transgression," Geologic Society of America Bulletin, Vo1 82, pp 2131-2158.

Kriebel, D. L. 1982. "Beach and Dune Response to Hurricanes," M.S. Thesis, Department of Civil Engineering, University of Delaware, Newark, Del.

- 1984a. "Beach Erosion Model (EBEACH) Users Manual, Volume I: Description of Computer Model," Beaches and Shores Technical and Design Memorandum No. 84-5-I, Division of Beaches and Shores, Florida Department of Natural Resources, Tallahassee, Fla.

- 1984b. "Beach Erosion Model (EBEACH) Users Manual, Volume II: Theory and Background," Beaches and Shores Technical and Design Memorandum No. 84-5-II, Division of Beaches and Shores, Florida Department of Natural Resources, Tallahassee, Fla.

1986. "Verification Study of a Dune Erosion Model," Shore and Beach, Vol 54, No. 3, pp 13-20.

Kriebel, D. L., and Dean, R. G. 1985a. "Beach and Dune Response to Severe Storms," Proceedings of the 19th Coastal Engineering Conference, American Society of Civil Engineers, pp 1584-1599.

- 1985b. "Numerical Simulation of Time- Dependent Beach and Dune Erosion," Coastal Engineering, Vol 9, pp 221-245.

- 1985c. "Estimates of Erosion and Mitigation Requirements Under Various Scenarios of Sea Level Rise and Storm Frequency for Ocean City, Maryland," Preliminary Report, Coastal and Oceanographic Engineering Department, University of Florida, Gainesville, Fla.

Leatherman, S. P. 1976. "Barrier Island Dynamics: Overwash Processes and Eolian Transport," Proceedings of the 15th Coastal Engineering Conference, American Society of Civil Engineers, pp 1958-1974.

$\overline{\mathrm{Pa}}$. ., ed. 1981. Overwash Processes, Hutchinson Ross, Stroudsburg, 
Leatherman, S. P., Williams, A. T., and Fisher, J. S. 1977. "Overwash Sedimentation Associated with a Large Scale Northeaster," Marine Geology, Vol 24, pp 109-121.

Leont'ev, I. O. 1985. "Sediment Transport and Equilibrium Profile," Coastal Engineering, Vol 9, pp. 277-291.

Moore, B. 1982. "Beach Profile Evolution in Response to Changes in Water Level and Wave Height," unpublished M.S. Thesis, Department of Civil Engineering, University of Delaware, Newark, Del.

Morgan, J. P. 1959. "Coastal Morphological Changes Resulting from Hurricane 'Audrey'," Proceedings of the Salt Marsh Conference, Sapelo Island Georgia, Marine Institute, University of Georgia, pp 32-34.

Otvos, E. G., Jr. 1965. "Sedimentation-Erosion Cycles of Single Tidal Periods on Long Island Sand Beaches," Journal of Sedimentary Petrology, Vol 35, pp 604-609.

- 1979. "Barrier Island Evolution and History of Migration, North Central Gulf Coast," in Leatherman, S. P.. ed., Barrier Islands from the Gulf of St. Lawrence to the Gulf of Mexico, Academic Press, New York, N.Y., pp 291-319.

Nummedal, D. 1982. "Hurricane Impact on Gulf Coast Barriers," Final Report No. 2, Office of Naval Research, Louisiana State University, Baton Rouge, La.

Pierce, J. W. 1969. "Sediment Budget Along a Barrier Island Chain," Sedimentary Geology, Vol 3, pp 5-16.

8, pp 230-234.

1970. "Tidal Inlets and Washover Fans," Journal of Geology, Vol

Rosen, P. S. 1979. "Aeolian Dynamics of a Barrier Island System," in Leatherman, S. P., ed., Barrier Islands from the Gulf of St. Lawrence to the Gulf of Mexico, Academic Press, New York, N.Y., pp 81-98.

Sallenger, A. H., Holman, R. A., and Birkemeier, W. A., 1985. "Storm Induced Response of a Nearshore-Bar System," Journal of Marine Geology, Vol 64, pp 237-257.

Sargent, F. E. and Birkemeier, W. A. 1985. "Application of the Dutch Method for Estimating Storm-Induced Dune Erosion," Instruction Report CERC-85-2, US Army Engineer Waterways Experiment Station, Coastal Engineering Research Center, Vicksburg, Miss.

Saville, T. 1957. "Scale Effects in Two-Dimensional Beach Studies," Transactions, 7 th Meeting of the International Association of Hydraulic Research, pp A3-1 - A3-11.

Schwartz, R. K. 1975. "Nature and Genesis of Some Storm Washover Deposits," CERC TM-61, US Army Engineer Waterways Experiment Station, Coastal Engineering Research Center, Vicksburg, Miss. 
Scott, A. J., Hoover, R. A., and McGowan, J. H. 1969. "Effects of Hurricane 'Beulah,' 1967 on Texas Coastal Lagoons and Barriers," in Castanares, A. A., and Phleger, F. B., eds., Coastal Lagoons, A Symposium, Universidad Nacional Autonoma De Mexico, pp 221-236.

Shore Protection Manual. 1984. 4th ed., 2 vols, US Army Engineer Waterways Experiment Station, Coastal Engineering Research Center, US Government Printing Office, Washington, D.C.

Short, A. D. 1975. "Multiple Offshore Bars and Standing Waves," Journal of Geophysical Research, Vol 80, No. 27, pp 3838-3840.

Strahler, A. N. 1966. "Tidal Cycle of Changes on an Equilibrium Beach," Journal of Geology, Vol 74, pp 247-268.

Sunamura, T., and Horikawa, K. 1975. "Two-Dimensional Beach Transformation due to Waves," Proceedings of the 14th Coastal Engineering Conference, American Society of Civil Engineers, pp 920-938.

Swain, A., and Houston, J. R. 1983. "A Numerical Model for Beach Profile Development," Proceedings of the 6th Canadian Hydrotechnical Conference, Canadian Society for Civil Engineering, pp 777-785.

- 1985. "On-Offshore Sediment Transport Numerical Model," Proceedings of the 19th Coastal Engineering Conference, American Society of Civil Engineers, pp 1244-1251.

Swart, D. H. 1974. "Offshore Sediment Transport and Equilibrium Beach Profiles," Publication No. 131, Delft Hydraulics Laboratory, Delft, The Netherlands.

- 1975. "A Schematization of Onshore-Offshore Transport," Proceedings of the 14th Coastal Engineering Conference, American Society of Civil Engineers, pp 885-900.

- 1977. "Predictive Equations Regarding Coastal Transports,"

Proceedings of the 15th Coastal Engineering Conference, American Society of Civil Engineers, pp 1113-1132.

Tetra Tech, Inc. 1983. "Storm Induced Coastal Erosion in North Carolina: Final Report," prepared for the Federal Emergency Management Agency, Washington, D.C.

US Army Engineer District, Galveston. 1975. "Guidelines for Identifying Coastal High Hazard Zones."

US Army Engineer District, New Orleans. 1965. "Hurricane Betsy."

Vallianos, L. 1975. "Beach Fill Planning-Brunswick County, North Carolina," Proceedings of the 14th Coastal Engineering Conference, American Society of Civil Engineers, pp 1350-1369. 
van de Graaff, J. 1983. "Probabilistic Design of Dunes," Proceedings of Coastal Structures '83, American Society of Civil Engineers, pp 820-831.

- 1986. "Probabilistic Design of Dunes; An Example from The Netherlands," Coastal Engineering, Vo1 9, pp 479-500.

Vellinga, P. 1982. "Beach and Dune Erosion During Storm Surges," Coastal Engineering, Vol 6, pp 361-389.

- 1983a. "Verification of Predictive Computational Model for Beach and Dune Erosion During Storm Surges," Delft Hydraulics Laboratory, Delft University of Technology, Delft, The Netherlands.

- 1983b. "Predictive Computationa1 Mode1 for Beach and Dune Erosion," Proceedings of Coastal Structures '83, American Society of Civil Engineers, pp 806-819.

- 1984. "A Tentative Description of a Universal Erosion Profile for Sandy Beaches," Coastal Engineering, Vol 8, pp 171-188.

- 1986. "Beach and Dune Erosion During Storm Surges," Communications No. 372, Delft Hydraulics Laboratory, Delft University of Technology, Delft, The Netherlands.

Wang, H. 1985. "Beach Profile Modeling," in Dalrymple, R. A., ed., Physical Modeling in Coastal Engineering, Balkema, Boston, Mass., pp 237-271.

Wilby, F. B. et al. 1939. "Inspection of Beaches in Path of the Hurricane of September 21, 1938," Shore and Beach, Vol 7, pp 43-47.

Williams, P. J. 1978. "Laboratory Development of a Predictive Relationship for Washover Volume on Barrier Island Coastlines," M.S. Thesis, Department of Civil Engineering, University of Delaware, Newark, Del.

Wright, L. D. et al. 1979. "Morphodynamics of Reflective and Dissipative Beach and Inshore Systems: Southeastern Australia," Marine Geology, Vol 32, pp 105-140.

Wright, I. D., and Short, A. D. 1983. "Morphodynamics of Beaches and Surf Zones in Australia," in Komar, P.D., ed., Handbook of Coastal Processes, CRC Press, Boca Raton, Fla., pp 35-64.

Yang, W-C. 1981. "Surf Zone Properties and On/Offshore Sediment Transport," unpublished Ph.D. Thesis, Department of Civil Engineering, University of Delaware, Newark, Del. 


\section{APPENDIX A: DISCUSSION AND ANNOTATED \\ BIBLIOGRAPHY OF OVERWASH LITERATURE}

\section{Introduction}

1. Overwash is defined by the American Geological Institute (Bates and Jackson 1980 )* as:

a. A mass of water representing the part of the uprush that runs over the berm crest (or other structure) and that does not flow directly back to the sea or lake.

b. The flow of water in restricted areas over low parts of barriers or spits, especially during high tides or storms.

Although this definition applies to any low shoreline, including reef islands or rocky spits, in this study only overwash along sandy barrier beaches, especially if a frontal duneline is present, is discussed.

2. A washover is the geomorphic feature produced by an overwash event. The passage through the duneline is called the throat (Figure A1). The fan is the portion of the washover deposited on the island or beach interior where the landward flow is unrestricted by topography (Figure A1). Effects of coastal storms on beaches are progressive. Initial beach erosion and dune scarping will be followed by slight overtopping of the lower portions of the duneline as the water level and wave runup increase. With continued water level rise, significant dune overtopping will occur, with associated fan deposition (Figure A2). If the surge level rises enough, complete overtopping of the duneline will occur, possibly resulting in total erosion of the frontal dune. Significant storm duration without an increase in surge level may produce a similar progression of effects, with dune erosion causing overwash to occur at lower water levels. If landward flow of water is concentrated in one area, deep erosion of an overwash throat may occur, resulting in formation of a tidal inlet, although most tidal inlets formed during storms result from seaward flow of elevated bay water (Hite 1924, Pierce 1970).

3. Most early research on overwash was primarily qualitative; whereas

* References cited in the Appendix are included in the References at the end of the main text. 


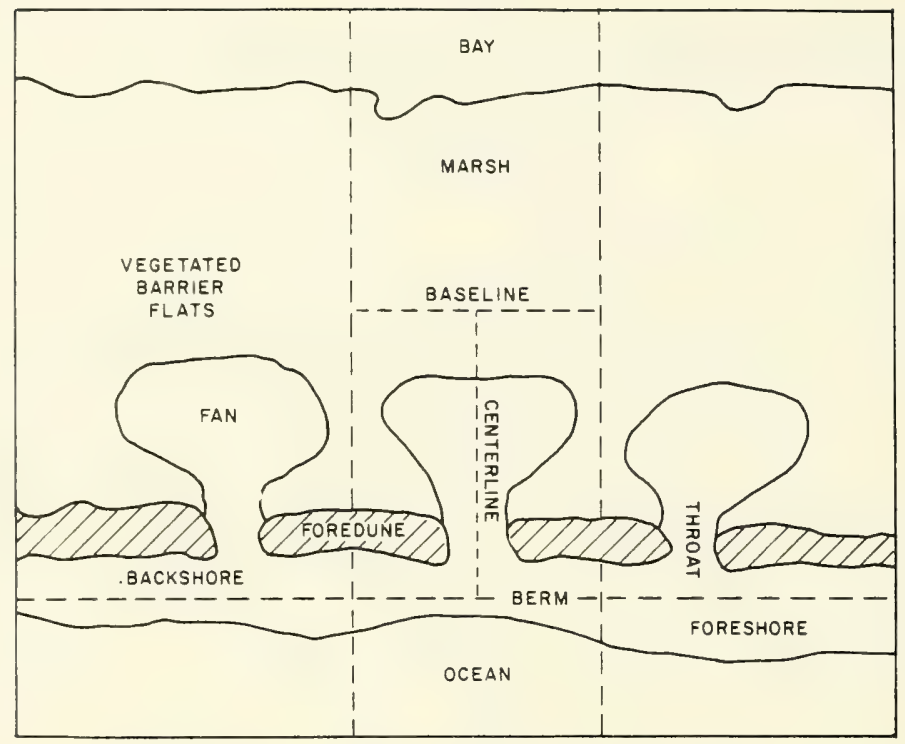

Figure Al. Planform of overwash features

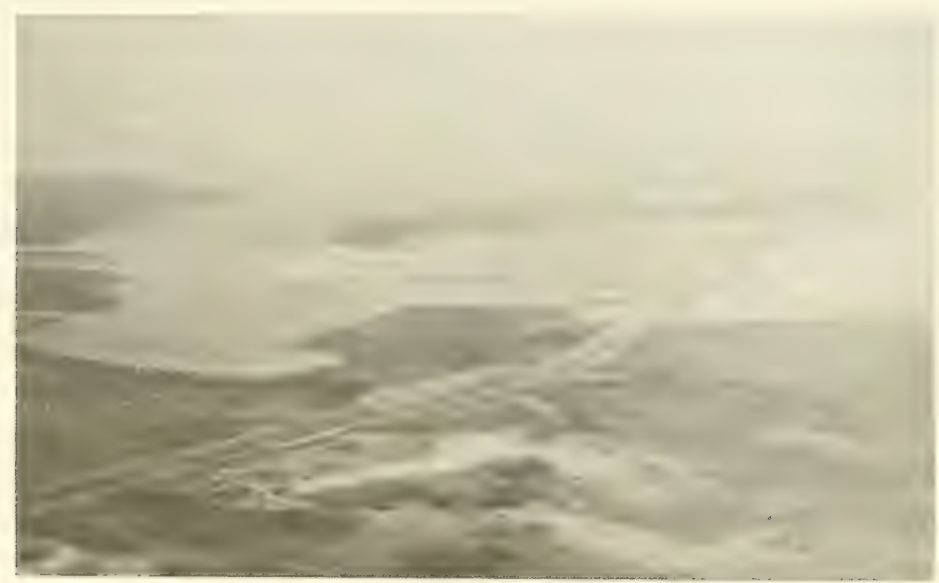

Figure A2. Large overwash fan on the Delaware coast after the March 1962 northeaster

quantitative analyses and detailed site descriptions have been completed in more recent years (Leatherman 1981). Effects of the great New England 
Hurricane of 21 September 1938 upon the north Atlantic coast from Long Island, New York, to Cape Cod, Massachusetts, were described by several researchers (Wilby et al, 1939 and Howard 1939). The storm made landfall in southwest Rhode Island, with an estimated tide of $4.9 \mathrm{~m}$ at Point Judith (Wilby et al. 1939). Although this storm was of short duration, with the rise and fall of the storm force ending in 5 to $6 \mathrm{hr}$, total destruction of coastal communities occurred. The significance of overwash in widening the islands and importance of storm-induced inlet formation was noted by these authors. Wilby et al. (1939) concluded that barrier dunes provide some protection for coastal buildings during storms, and wider beaches may afford protection to landward areas.

4. Many of the earlier, qualitative studies of overwash were completed along the gulf coast (Morgan 1959, Fisk 1959, Scott, Hoover, and McGowan 1969, and Hayes 1967). In this microtidal setting (tidal range less than $2 \mathrm{~m})$, barriers are typically long and linear, with few permanent tidal inlets. Deposition of continuous overwash aprons (coalescing washover fans) occurs on the landward sides of barriers during storm passage. More recent work has revealed that complete overwash of low profile Gulf barriers may occur during hurricane passage (Otvos 1979 and Nummedal 1982), resulting in poststorm submergence. Years later, emergence and redevelopment may occur in more landward positions, as documented by Otvos (1979) for portions of the Chandeleur Island chain of Louisiana.

5. One of the first detailed analyses of a single washover fan was conducted by Andrews (1970) at St. Joseph Island, Texas. This washover fan, measuring 6.9 by $6.4 \mathrm{~km}$, was semicircular in plan, and wedge-shaped in vertical section, thinning and decreasing in mean grain size toward the bay. Andrews noted that the site of this washover was predated by a much earlier flood-tidal delta. This observation, along with work by Kraft (1971), demonstrated the importance of closed inlet locations, which are topographically lower than adjacent island areas, as future sites of increased overwash activity. Geomorphic (Fisher 1967) and stratigraphic (Knowles and Davis 1983) studies indicate that past inlet locations are frequently sites of inlet reopening during storms.

6. One of the first quantitative investigations of overwash effects was completed by Pierce (1969) along the Outer Banks of North Carolina. Historical maps, charts, and surveys were used to estimate the backbarrier 
sediment contribution from various processes. A summary of the contribution of landward sediment transfer processes at several Atlantic coast localities is contained in Table Al. Eighty-five percent of the North Carolina coast has been subjected to overwash between 1938 and 1974 (Boc and Langfelder, 1977). These data indicate that the magnitude of overwash varies significantly with locality.

Table A1

Contribution of Overwash, Wind, and Tidal Delta Deposition to Landward Sediment Transport

\begin{tabular}{|c|c|c|c|c|}
\hline Locality & $\begin{array}{l}\text { Overwash } \\
\% \\
\end{array}$ & $\begin{array}{c}\text { Wind } \\
\% \\
\end{array}$ & $\begin{array}{c}\text { Flood Tidal } \\
\text { Delta } \\
\% \\
\end{array}$ & Data Source \\
\hline $\begin{array}{l}\text { Outer Banks, } \\
\text { North Carolina }\end{array}$ & 13 & 14 & 73 & Pierce (1969) \\
\hline $\begin{array}{l}\text { Assateague Island, } \\
\text { Maryland }\end{array}$ & 12 & 6 & 82 & Bartberger (1976) \\
\hline $\begin{array}{l}\text { Ma Ipeque barrier } \\
\text { system, Canada }\end{array}$ & 48 & & 52 & Armon (1979) \\
\hline Rhode Is land & 43 & $3^{*}$ & 57 & $\begin{array}{l}\text { Fisher and Simpson } \\
\text { (1979) }\end{array}$ \\
\hline
\end{tabular}

* Combined effects of wind and overwash.

7. A detailed study of overwash texture, composition, and structure was completed by Schwartz (1975). Volume estimates from individual storms were also compiled. During a northeaster (extratropical storm) in February 1973, a minimum estimate of $302,000 \mathrm{~m}^{3}$ of washover occurred between Caffeys Inlet and Buxton, North Carolina for an average washover volume of $2.7 \mathrm{~m}^{3} / \mathrm{m}$ of beachfront for the 113-km stretch of coastline. Assuming that only 20 to 25 percent of the barrier experienced overwash, the volume of overwash per unit of overtopped beach was 10.78 to $13.5 \mathrm{~m}^{3} / \mathrm{m}$ of beach (Schwartz 1975).

8. Actual field measurement of overwash processes was accomplished by Fisher, Leatherman, and Perry, (1974) at Assateague Island. Overwash velocities were measured during storm events, and accurate measurements were made of the amounts of beach erosion, dune scarping, and overwash deposition. Instantaneous velocities of overwash surges ranged from 0.5 to $2.4 \mathrm{~m} / \mathrm{sec}$ with a mean of $1.5 \mathrm{~m} / \mathrm{sec}$. Flow depths averaged $0.2 \mathrm{~m}$.

9. Leatherman, Williams, and Fisher (1977) determined that storm tide height is the most important parameter in determining the magnitude of an 
overwash. During a 26-month study along Assateague Island, seven overwash events were recorded. Although backshore deposition occurred during overwash, a slight decrease in volume occurred because of poststorm eolian transport back to the beach (Leatherman 1976). Net seaward transport of overwash deposits by wind was also documented along the Tabusintac barrier system in New Brunswick, Canada (Rosen 1979).

10. The influence of human activity upon natural beach processes has been a subject of study for many years. One major debate involves the effects of artificial dunes upon storm-induced beach erosion. Some researchers believe that increased turbulence resulting from wave backwash from the dune front results in increased beach erosion. These researchers also believe that an artificial duneline will prevent island-building overwash. Other researchers believe that erosion of artificial dunes during storms nourishes eroding beaches, protecting against more severe beach erosion (Leatherman 1981). Other human activities influencing natural storm processes include the formation of overwash channels at locations of beach access cuts through the duneline which occurred along the eastern portion of Galveston Island, Texas, during Hurricane Alicia (Dupre 1985). Although groins are often used to stabilize beaches, during severe storms they may promote localized erosion and overwash, as shown in Figures A3a and b (US Army Engineer District, New Orleans 1965).

\section{Selected Bibliography on Overwash}

11. The following bibliography of overwash literature includes 21 abstracts (or summaries) selected from a review of over 100 overwash publications. Dozens of articles were excluded because of minor subject coverage and space limitations. Only reports which are particularly historically important or those which discuss significant qualitative or quantitative analysis are included.

Andrews, P. B. 1970. "Facies and Genesis of a Hurricane-Washover Fan, St. Joseph Island, Central Texas Coast," Report No. 67, Texas Bureau of Economic Geology, Austin, Tex.

Washover fans are subaerial coastal landforms, semicircular in map view, and wedge-shaped in cross section. They form on the bayside of many barrier islands along the Texas Gulf Coast. Washover fans are composed largely of 

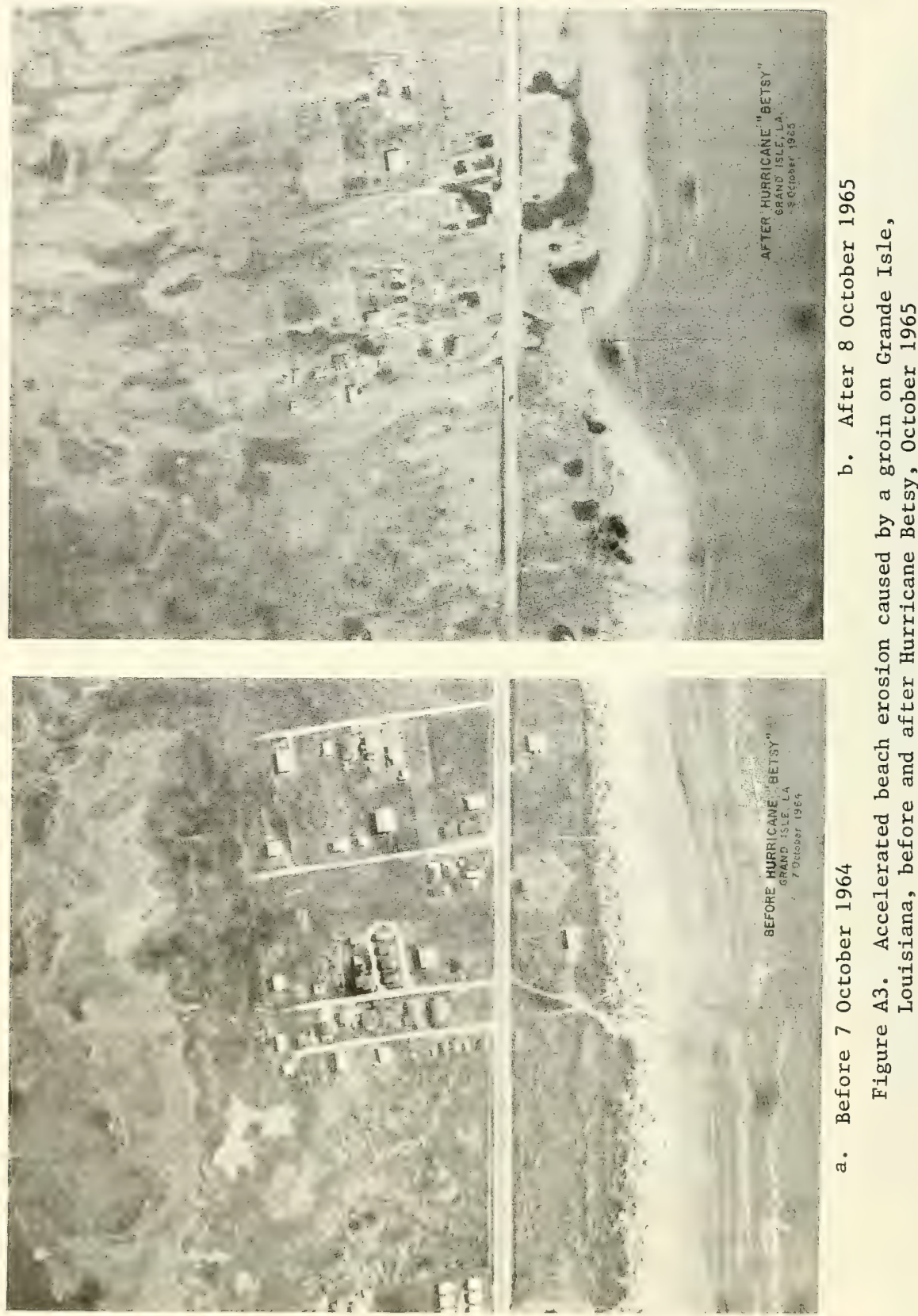
sediment that had been carried across a barrier island and dumped in the adjoining bay by catastrophic storms, such as hurricanes. One such fan, measuring $4-1 / 4$ by 4 miles ( 6.9 by $6.4 \mathrm{~km}$ ), occurs at the north end of St. Joseph Island, on the central Texas coast. It grades northeastward into a subaerial tidal delta. The surface facies of these two features and the adjoining barrier island nucleus, as well as the geometry of the component sediment bodies, are described in detail. The data upon which descriptions and interpretations are based were obtained by digging trenches and pits, up to $8 \mathrm{ft}(2.4 \mathrm{~m})$ deep.

The washover fan is fed via a low-level washover channel, Vincent Slough, which is cut through the barrier island nucleus. The fan is accreting laterally into the adjoining bay, Aransas Bay, through the deposition of shell debris and sand that are derived from the inner neritic zone of the continental shelf. Periodic hurricane surges, both flood and ebb, deposit large volumes of sediment in Aransas Bay. The washover fan thus built up is 25 to 30 in. (63.5 to $76.2 \mathrm{~cm}$ ) thick at its periphery and thickens to more than $50 \mathrm{in.}(127 \mathrm{~cm})$ near its apex. It is composed predominantly of an imbricate set of sheet sands, each 3 to 15 in. $(7.6$ to $38.1 \mathrm{~cm})$ thick. Each washover sand rests on a sharp scour base and consists of a shell placer at the base that grades upward into horizontally laminated, shell-free, clean sand.

The washover fan is a two-part feature. One part is still actively prograding, albeit very slowly, and mainly consists of sand of the washover sand, eolian flat, low-mound, and high-mound sand facies. The second part is stagnant, and hurricane surge has been excluded from it for some considerable time. The lower half of the stagnant fan segment is dominated by the washover sand facies, while the upper half is dominated by muddy sand to mud of the marsh, mudflat, and pond facies. The superimposed eolian mounds consist of low-mound, high-mound sand, and high-mound mud facies. With exclusion of the scouring action of hurricane surge waters, eolian mounds on the stagnant fan segment are prograding laterally unimpeded, thus slowly changing the distributary channel pattern and reducing channel dimensions.

Radiocarbon dates show that the tidal delta began to form at least 2,400 years ago; the washover fan began to form about 1,700 years ago. Progradation was rapid at first but subsequently slowed considerably. Progradation has been minimal since about 450 years before present. (Author)

Armon, J. W. 1979. "Landward Sediment Transfers in a Transgressive Barrier Island System, Canada," in Leatherman, S. P., ed., Barrier Islands: From the Gulf of St. Lawrence to the Gulf of Mexico, Academic Press, New York, N.Y., pp 291-319.

The largely transgressive Malpeque barrier system in the southern Gulf of St. Lawrence, Canada, was investigated to assess the influence of a restricted sea environment on barrier island morphology and dynamics. Wave dimensions are restricted by the limited wind fetches and shallow-water depths in the southern Gulf, and the islands are protected from storm action for 2-4 months in winter by shorefast ice. The barrier islands in the transgressive section of this barrier system are narrow, 150 to $450 \mathrm{~m}$ in width, with the dune zone commonly dominated by the seawardmost dune. The continuous dune cover restricts overwash during storms, and the wellvegetated dune surface limits sand transport landward of the seawardmost 
dune. Consequently, over 90 percent of measured sediment gains to the barrier system during a 33-year period (1935-1968) were located in the vicinities of existing or closed inlets. Of these inlet-associated gains, over 40 percent by volume occurred at the sites of "temporary" inlets, open for only part of the 210-year period of map record. This occurrence reflected dune and foreshore recovery at former sites, resulting largely from wind action and storm overwash. In all, 48 percent of the measured volumetric gains to the barrier system arose from storm overwash and wind transport at locations other than contemporary inlets, while the remaining 52 percent were measured at the open inlets. Comparisons drawn between the transgressive barrier coast at Malpeque and analogous coasts to the south suggest some variability in the dynamic response among barriers in different coastal environments. (Author)

Boyd, R., and Penland, S. 1981. "Washover of Deltaic Barriers on the Louisiana Coast," Transactions, Gulf Coast Association of Geological Societies, Vo1 31, pp 243-248.

Washover feposits on Louisiana barriers often account for over 50 percent of total sediment storage. Louisiana barriers have evolved by deltaic distributary abandonment, and continuing sequential evolution of Mississippi Delta complexes has generated a corresponding sequence of transgressive barriers. The resulting spectrum of barrier geometries has provided an ideal field site for the examination of washover form variability and its controlling processes. (Authors)

Cleary, W. J., and Hosier, P. E. 1979. "Geomorphology, Washover History, and Inlet Zonation: Cape Lookout, NC, to Bird Island, NC," in Leatherman, S. P., ed., Barrier Islands: From the Gulf of St. Lawrence to the Gulf of Mexico, Academic Press, New York, N.Y., pp 237-271.

Seventeen islands and two mainland beaches comprise the 237-km shoreline between Cape Lookout and Bird Island, North Carolina. The area, characterized by diverse physiography, has been divided into four major geomorphic sections. Shackleford, Bogue, Bear, and Brown Islands comprise the northernmost $75 \mathrm{~km}$ of shoreline. These barriers display vegetated beach ridges, massive dunes, and few washovers. Wide shallow lagoons with little tidal marsh vegetation back these islands. The $50-\mathrm{km}$ section to the southwest consists of Onslow and Topsail Beaches where washovers are more abundant; many have occurred prior to 1938. Inlet zone maps indicate that inlets are more active in this section than in the previous area. These maps are based on the location of marsh islands found in the vegetated lagoons and historic maps and charts. The 60-km section from Lea Island to Fort Fisher-South includes six islands and the Carolina-Kure Beach mainland. Inlets have been particularly active within this area during the past 150 years, accounting for over 68 percent of the surface sediments. This area has been impacted by washovers chronically during the past 40 years, and vegetation patterns suggest occurrences which predate 1900 . Washover-related physiography includes a number of identifiable shoreline features which suggest a cyclic pattern of washover followed by recovery. Both physiographic and vegetational recovery patterns differ, depending upon the grain size distribution of the washover sediments. 
It is postulated that changes in the barrier islands during the past 3,500 years have been most significant in the Lea Island to Fort Fisher-South section, creating absent, scattered, and single dune ridge morphology along much of the shoreline. West of Cape Fear to Bird Island, the remaining $52 \mathrm{~km}$ consists of the Caswell-Yaupon-Long Beach mainland and Holden, Ocean Isle, Sunset, and Bird Islands. Susceptibility to washover within the region ranges from high to low, while inlets have had a significant impact on the area. The interrelationships among washover potential, vegetation cover, and dune morphology have been used to develop a generalized model of the shoreline features and processes of the Cape Lookout to Bird Island section of North Carolina. (Authors)

Deery, J. R., and Howard, J. D. 1977. "Origin and Character of Washover Fans on the Georgia Coast, U.S.A.," Transactions, Gulf Coast Association of Geological Societies, Vol 27, pp 259-271.

Washover fans on the Georgia coast form initially in response to storms but continue to develop after the storm has passed. Most storm-induced fans flood only during spring tides, yet some are continuously active on a day-today basis. All washovers have essentially the same surface morphology and internal physical and biogenic sedimentary structures and, based on these features, the washover area can be subdivided into beach, fan, and marginal facies.

Our field studies, centered primarily on Ossabaw, St. Catherines, and Sapelo Islands, indicate that Georgia washover fans have an "active" and "passive" phase of development and each leaves a characteristic record in fan stratigraphy and sedimentary structures. The "active" phase occurs when waves overtop the beach crest and water and sediments flow landward into the backbarrier salt marsh. At such times subhorizontal stratification, ripple lamination, planar foreset crossbedding, and trough crossbedding form. The "passive" phase occurs when the fan is not undergoing overwash from the beach. During this time eolian and biogenic processes and rain runoff are the principal agents in the formation of sedimentary climbing ripples. Although less dynamic in origin, the "passive" phase structures represent the greatest period of time in washover fan development. (Authors)

Dolan, R., and Godfrey, P. 1973. "Effects of Hurricane Ginger on the Barrier Islands of North Carolina," Geological Society of America Bulletin, Vo1 84, pp 1329-1333.

The two barrier island systems of North Carolina responded to the storm waves and surges of Hurricane Ginger in a strikingly different manner. Within the northern sector, which has been stabilized by man, erosion and dune recession were extensive. In the southern sector, as yet relatively unmodified, overwash and associated deposition were the dominant processes. This difference offers important geologic, ecologic, and land management implications. (Authors) 
Fisher, J. J., and Simpson, E. J. 1979. "Washover and Tidal Sedimentation Rates as Environmental Factors in Development of a Transgressive Barrier Shoreline," in Leatherman, S. P., ed., Barrier Islands: From the Gulf of St. Lawrence to the Gulf of Mexico, Academic Press, New York, N.Y., pp 127-148.

Washover fans and tidal deltas are significant reservoirs of sediment in barrier island systems. These backbarrier and lagoonal deposits also represent important sediment sinks in the overall littoral sediment budget of a shoreline. Along the 40-km-long Rhode Island south shore barrier beaches, extensive washover fans, resulting from hurricanes, and several inlet deposits are prevalent. A long-term quantitative analysis of the subtidal and supratidal sedimentation of these units from 1939-1975 was conducted using photogrammetric techniques. Backbarrier sedimentation features were first identified in the field to develop "ground-truth" keys to identify the features on the aerial photography. Sediment units were measured on each set of aerial photographs by point-counting of grids. These photographic measurements were scaled by using ground survey data.

During the 36-year study period, the total areal sedimentation change of the supratidal washover deposits was $+522,790 \mathrm{~m}^{2}$. The subtidal washover deposits amounted to $+267,950 \mathrm{~m}^{2}$, for a total washover sedimentation accumulation of $790,740 \mathrm{~m}^{2}$. For the same time period, the total area change of supratidal flood tidal deltas at the inlets was $+188,240 \mathrm{~m}^{2}$, while that of the subtidal tidal deposits was $+862,320 \mathrm{~m}^{2}$ for a total tidal delta deposition of $+1,050,560 \mathrm{~m}^{2}$. This analysis indicates that during this 36-year period, tidal delta sedimentation is 1-1/3 times more effective than washover in the landward transportation, deposition, and storage of sediment.

This barrier coast, in addition to transgressing, is eroding at the rate of $0.7 \mathrm{~m} / \mathrm{yr}$. An inverse relationship exists between overwash occurrence and barrier island width, which can be further related to beach erosion. Measured beach erosion over the 36-year period is directly related to the rate of overwash occurrences at different points along the coast. (Authors)

Fisher, J. S. 1980. "Field and Laboratory Study of Storm Swash and Overwash Dynamics," Final Report, US Army Research Office, Arlington, Va.

Field studies at Assateague Island quantified the flux and frequency of overwash. Repeated surveys at several washovers revealed that stormgenerated overwash transports sand landward up to $100 \mathrm{~m}$ past the beach crest for storms characterized by 1-year return periods. Poststorm winds transport this material seaward, past the frontal duneline. Thus, overwash of this magnitude does not supply permanent sediment to the island interior or bay. Very large storms could transport sediment to the bay, but this is the exception at the study site. Laboratory and field studies show that backshore structures, e.g., dunes or seawalls, enhance the backwash, and thus beach erosion. In the case of dunes, however, the dune erosion feeds the storm beach and thus offsets the erosion potential. A separate laboratory study demonstrated that heavy mineral washover laminations can be related to the depth and velocity of individual overwash surges.

(Author) 
Godfrey, P. J., Leatherman, S. P., and Zaremba, R. 1979. "A Geobotanical Approach to Classification of Barrier Beach Systems," in Leatherman, S. P., ed., Barrier Islands: From the Gulf of St. Lawrence to the Gulf of Mexico, Academic Press, New York, N.Y., pp 99-126.

Barrier beaches from Cape Cod to Cape Lookout have been studied using geological and ecological techniques. The resulting data have been integrated to demonstrate the interrelationships among plants, processes, and barrier morphology. From this analysis a general pattern for east coast barriers undergoing recession emerges. The regional variation in vegetation and its response to overwash have been found to be an important criterion for classification. The vegetation of Northern barrier beaches is dominated by American beach grass (Ammophila breviligulata) in the dune strand community and by the decumbent form of salt meadow cordgrass (Spartina patens) in the high marsh. Salt meadow cordgrass is killed by overwash burial and is replaced by dune vegetation, originating from seeds and plant fragments found in the drift lines. The stratigraphy of a transgressive barrier in the Northeast shows a sharp demarcation between the salt marsh and overlying washover/dune sands.

In the Southeast, sea oats (Uniola paniculata) dominate the dune grasslands, while the upright variety of Spartina patens is ubiquitous. The dunes along the Outer Banks develop initially as scattered clumps resulting from lack of well developed drift lines, irregular seed dispersal, and the clumped growth deposition on barrier flats and marshes in the absence of a continuous barrier duneline. The upright form of Spartina patens has the ability to grow through this overwash sediment and reestablish itself on the fan surface. An analysis of sedimentary sequences shows a deposit of clean overwash layers alternating with organic layers. These biogeological studies have shown the importance of regional variation in the vegetation in determining barrier beach topography. (Authors)

Hayes, M. O. 1967. "Hurricanes as Geological Agents: Case Studies of Hurricanes Carla, 1961, and Cindy, 1963," Texas Bureau of Economic Geology, Report of Investigations No. 61.

Tropical storms, which cross the Texas coastline with a frequency of 0.67 storms per year, play a major role in nearshore sedimentation on the south Texas coast. Greatest geological effects of these storms are produced by wind-driven waves and by storm surges.

The comparison of a part of the nearshore environmental complex of a segment of the south Texas coast before and after Hurricane Carla, 1961, shows the effects of the storm. The storm removed a belt of foredunes 20 to 50 yards $(15 \mathrm{~m})$ wide from the seaward side of Padre Island and left the foredune ridge with wave-cut cliffs up to $10 \mathrm{ft}(3 \mathrm{~m})$ high. The formation of a broad, flat hurricane beach drastically altered the beach profile. The landward side of the barrier island (wind-tidal flats) received much washover material containing surf zone and beach mollusks. The storm also submerged high-level mud flats along the landward side of Laguna Madre and covered them with a fresh layer of mud. A much milder storm (Cindy) passed through the area in September 1963, and a small swash bar was deposited over the seaward edge of the preexisting hurricane beach. (Author) 
Kahn, J. H., and Roberts, H. H. 1982. "Variations in Storm Response Along A Microtidal Transgressive Barrier-Island Arc," Sedimentary Geology, Vol 33, pp 129-146.

Storm response along the transgressive Chandeleur barrier island arc southeast of the Mississippi Delta plain is variable because of local differences in sediment supply, shoreline orientation, and barrier morphology. A study of the morphological impact of Hurricane Frederic (1979) affirmed that tropical storms are the primary agents causing erosion and migration of this barrier arc.

Frederic's greatest impact was in the duneless southern Chandeleurs where sheet-flow overwash caused flattening of the barrier profile, destruction of a strip of marsh 50 to $100 \mathrm{~m}$ wide, and shoreline retreat of approximately $30 \mathrm{~m}$. In contrast, overwash in the northern Chandeleurs was confined between dunes in channels established by previous storms. This channelized overwash breached the northern Chandeleur barriers in 19 places. As Frederic passed, return flow through these channels transported overwash sediment back to the nearshore zone. These ebb deposits were a source for longshore drift sediments which quickly sealed storm channels, reestablishing a coherent northern Chandeleur barrier arc.

These storm response patterns may help explain long-term changes in barrier morphology. During an 84-year period (1885-1969), the southern Chandeleurs decreased 41 percent in area, with an average retreat rate of 9.1 $\mathrm{m} / \mathrm{yr}$, compared to a 15 percent increase in area and an average shoreline retreat rate of $7.2 \mathrm{~m} / \mathrm{yr}$ for the northern Chandeleurs. (Authors)

Kraft, J. C., et al. 1979. "Processes and Morphologic Evolution of an Estuarine and Coastal Barrier System," in Leatherman, S. P., ed., Barrier Islands: From the Gulf of St. Lawrence to the Gulf of Mexico, Academic Press, New York, N.Y., pp 149-184.

Coastal barriers in Delaware are rapidly transgressing. Wave-dominated processes are the most important single factor in determining the volume of sediment in motion. Availability of sediment from the continental shelf, erosion of the barrier itself, and erosion of headlands determines whether or not a barrier can exist and evolve.

Studies of the internal structure of the barriers indicate that washover processes and flood-tidal delta deposition are the dominant factors in the landward transgression. Wind-transported sand is of secondary importance, derived from the beach berm and washover fans and transported to coast parallel dunes. (Authors)

Leatherman, S. P. 1976. "Barrier Island Dynamics: Overwash Processes and Eolian Transport," Proceedings of the 15th Coastal Engineering Conference, American Society of Civil Engineers, pp 1958-1974.

The northern $8 \mathrm{~km}$ of shoreline at Assateague Island, Maryland, are presently being eroded. During storms, swash surges are able to overtop the most landward (storm) berm as overwash, with deposition occurring on the barren flats. Where primary barrier dunes still exist, sediment-charged 
surges are funneled through breaches in the dune field for deposition of the entrained material on the washover fan.

Sediment budget computations show that there has been a small net loss of material at each washover area, in spite of seven discrete overwash events during a 26-month time interval. The predominant northwest winds effectively eroded the overwash material, transporting the majority of the sand back to the beach. This analysis indicates that there exists a balance between overwash and eolian processes with wind transport being slightly dominant. (Author)

Leatherman, S. P., Allan, T. W., and Fisher, J. S. 1977. "Overwash Sedimentation Associated with a Large-Scale Northeaster," Marine Geology, VoI 24, pp 109-121.

The 1 December 1974 northeaster was a significant event in terms of sediment transport with $20 \mathrm{~m}^{3}$ of sand per meter of dune breach being carried onto the backdune area of Assateague Island, Maryland, as overwash. Previous investigators have reported larger transport rates for landfall hurricanes, but this is the largest amount recorded for a winter northeaster. The Ash Wednesday Storm, 6-8 March 1962, was a much larger event, but no quantitative data exist for overwash deposition. (Authors)

Leatherman, S. P., ed. 1981. Overwash Processes, Benchmark Papers in Geology, Vol 58, Hutchinson Ross, Stroudsburg, $\mathrm{Pa}$.

This book includes a collection of reprints of some of the more significant historic and recent articles associated with overwash research. The book is divided into six parts: (1) early works; (2) coral reefs, islands, and cays; (3) estuaries and lakes; (4) barrier islands; (5) overwash deposits in geologic record; and (6) management implications. The significance of articles within each section is discussed by the editor.

Leatherman, S. P., and Zaremba, R. E. 1986. "Dynamics of a Northern Barrier Beach: Nauset Spit, Cape Cod, Massachusetts," Geological Society of America Bulletin, Vol 97, pp 116-124.

Quantitative analysis of historical shoreline (ocean and bay) and coastal environments (dune, salt marsh, shrub, washover, and sandy beach) change data for Nauset Spit, Cape Cod, Massachusetts, are described in this paper. There are marked differences in the relative role of the landward sediment transport processes along the Nauset barrier chain. In general, the barriers have been narrowing during the past century, and bayshore accretion has not been equal to ocean shoreline erosion rates. Inlets are largely responsible for bayside sedimentation, whereas overwash is not effective in maintaining width until the barrier slims considerably. While salt marshes form on intertidal washover deposits, the vast expanse of barrier-related marshes have developed atop flood-tidal deltas, and overwash subsequently has buried and killed the marshes. Therefore, massive washovers eventually become the sites of new dunes, often at the expense of marshes in the cyclic events of barrier evolution. (Authors) 
Maynard, A. K., and Suter, J. R. 1983. "Regional Variability of Washover Deposits on the South Texas Coast," Transactions, Gulf Coast Association of Geological Societies, Vol 33, pp 339-346.

Overwash processes play an important role in determining the stratigraphy of microtidal barrier islands. Along the microtidal coast of south Texas, regional variability in barrier island geometry produces a spectrum of washover types. South Padre Island is a low-profile, transgressive feature with a discontinuous to nonexistent foredune ridge. It displays sheet overwash, coalescing washover terraces, and washover fans fed by large hurricane channels. North Padre and Mustang Islands are highprofile barrier islands with continuous foredune ridges, and thus only small, discrete interdune washovers occur. The relict tidal inlets between Mustang and Padre Islands are the sites of the largest washovers in the system, termed reactivated tidal deltas. This last type, although relatively rare in modern washover deposits, is probably similar in mode of origin to the large lobate backbarrier features found on many high-profile barriers on the Texas coast. (Authors)

Pierce, J. W. 1970. "Tidal Inlets and Washover Fans," Journal of Geology, Vol 78, pp 230-234.

Tidal inlets and washover fans are genetically related. The resulting feature is dependent upon barrier configuration, depths in the lagoon adjacent to the barrier, and the direction from which the storm surge came, either from the sea or the lagoon.

Attack on barrier islands from the seaward side by waves overtopping the barrier will result in washover fans on wide barriers where extensive adjoining tidal flats are present. Inlets can be cut by this type attack on narrow barriers where no tidal flats are present. Storm surge from the lagoonal side, if channeled along tidal creeks, can easily cut inlets through a barrier. (Author)

Rosen, S. P. 1979. "Eolian Dynamics of a Barrier Island System," in Leatherman, S.P., ed., Barrier Islands: From the Gulf of St. Lawrence to the Gulf of Mexico, Academic Press, New York, N.Y., pp 81-98.

Eolian transport of sand was monitored by using directional sand traps on the beach, foredune, overwash and spit environments of Tabusintac barrier system in northeast New Brunswick. The total volume of sand moved over the system was computed from the measured transport rates.

A large volume of sand $\left(1,720 \mathrm{~m}^{3}\right)$ was transported in the alongshore directions from storm overwash deposits into vegetated backdune areas to produce vertical accretion. In 1977, the storm overwash deposits accounted for 8 percent of the subaerial volume of the system.

Net cross-island transport was offshore from overwash areas and the mid-backbeach $\left(1,556 \mathrm{~m}^{3}\right)$ in response to prevalent offshore winds. A comparable volume $\left(2,100 \mathrm{~m}^{3}\right)$ of sand was moved onshore from the beach to the foredune base. Approximately $220 \mathrm{~m}^{3}$ of this amount crossed accretional dune crests, but very little was transported up wave-eroded dune crests; hence, only the former grew vertically. The remainder was transported alongshore in 
the direction of net wave-induced longshore transport and resulted in the extension of the foredune into overwash and spit areas.

Overwash deposits serve as a source of sand, and these breaches in the barrier dune also act as corridors for eolian transport. The redistribution of storm overwash deposits by wind is important in effecting the vertical growth of a barrier island. (Author)

Schwartz, R. K. 1975. "Nature and Genesis of Some Storm Washover Deposits," CERC TM-61, US Army Engineer Waterways Experiment Station, Coastal Engineering Research Center, Vicksburg, Miss.

Under certain conditions large amounts of sediment are moved across the beach during storms and stored subaerially instead of being eroded from the beach and foredune and introduced, or simply returned seaward, into the littoral drift system. Washover occurrence is a function of the degree of storm surge and backshore-foredune relief. The shape and dimension of a washover sand body are largely controlled by the surrounding topography. The major immediate source of washover sediment during storm-surge flood is the beach and shoreface; the foredune may contribute variable amounts. Subenvironments of the backbarrier supply sediment during storm-surge ebb flow, and eolian processes add variable amounts of sediment during washover deposition depending upon storm wind intensity and duration. In turn, washover deposits serve as a sediment source to the poststorm eolian system or encroaching bodies of water, e.g., a transgressing sea.

Both structural and textural properties are explained by pulsating (discontinuous) unidirectional flow of sediment-charged water across the washover surface. Velocities imparted by the fluid surge of overwashing storm waves, combined with gravity effects due to a landward-sloping surface, result in the development of flow similar to sediment gravity flow. Each flow event results in initial scouring of the subaerial surface followed by the development of planar (horizontal) stratification, while injection into the more distal subaqueous setting results in the development of deltaforeset structures. Normal and inverse textural grading as well as textural coarsening in the direction of flow are also the products of this flow.

The observed washover properties and genetic interpretations describe washover response to two particular storm conditions. Although the same basic response is expected for storms of various magnitudes, modifications are expected. In response to a larger storm surge (e.g., hurricane) or a different topographical setting, storm surge-ebb may be an important factor in washover sedimentation. With a storm surge sufficient enough to keep the washover area submerged, flow characteristics will vary; therefore, textural-structural response properties will vary. On a smaller scale, temporal-spatial variations in the local setting (e.g., slope, initial flow velocity, sediment size and sorting, sediment-fluid concentration, and percolation) may also result in process-response variation.

The occurrence of washover suggests an important relationship to the littoral system in subaerial sediment storage versus permanent offshore sediment loss or temporary offshore storage. Washover contributes to the landward and vertical accretion of coarser detritus (relative to other facies) in the barrier environment. The sediment is stored until later erosion by similar storm processes, wind, incremental encroachment, and erosion by surrounding water bodies or other sediment processes. The 
landward sinks are considered temporary in an eroding beach. As the beach zone encroaches upon the washover deposits or redistributed washover sediment, the material is released to the littoral system. (Author Summary)

US Army Engineer Division, North Atlantic. 1963. "Report on Operation Five-High, March 1962 Storm," New York, N.Y.

This report offers one the most complete accounts of storm characteristics and effects of the 6-8 March 1962 northeaster upon the US Atlantic coast, from Virginia to New York. The storm lasted through five consecutive spring high tides, causing record water levels, extensive beach erosion, and damage to coastal structures. This report includes detailed discussion of storm characteristics and damage, emergency operations, and poststorm restoration projects. Extensive appendixes include excellent ground and aerial photography along the beaches, beach restoration data, and maps of overwash extent along Long Island, New York. (Knowles)

Wilby, F. B., et al. 1939. "Inspection of Beaches in Path of the Hurricane of September 21, 1938," Shore and Beach, Vol 7, pp 43-47.

Ground and air inspection of some of the beaches from Jacob Riis Park, Long Island to Chatham, Massachusetts, was conducted to record the effects of the hurricane and determine whether higher and/or wider beaches provide storm protection. Volume of sand fills (washovers) appeared to be greater than beach erosion volume in several localities, possibly indicating transport from underwater terraces (bars?) or offshore shoals, evidenced by cobbles with fresh kelp stalks attached which were found above the normal high-water line. Existing inlets were widened by the storm, and several new inlets were formed. A major geographic effect of the storm on Fire Island, New York, as viewed from the air, was widening of the island. Many washes (overwash channels) and several temporary inlets appeared to have occurred at places where dunes had been leveled for construction sites. Generally, the hurricane had the effect of eroding the foreshore and increasing the width of beaches by deposition of large, wide fills (washovers) landward of former berms. Dunes of sufficient height, stabilized by vegetation, provided some protection to landward areas. Wider beaches may have provided increased storm protection in other areas. (Knowles) 

